Portland State University

PDXScholar

The Determinants of Women's Work: A Case Study from Three Urban Low-income Communities in Amman, Jordan

Taghrid Khuri Tubbeh

Portland State University

Follow this and additional works at: https://pdxscholar.library.pdx.edu/open_access_etds

Part of the Public Affairs Commons, and the Urban Studies Commons Let us know how access to this document benefits you.

Recommended Citation

Tubbeh, Taghrid Khuri, "The Determinants of Women's Work: A Case Study from Three Urban Low-income Communities in Amman, Jordan" (1994). Dissertations and Theses. Paper 1208.

https://doi.org/10.15760/etd.1207

This Dissertation is brought to you for free and open access. It has been accepted for inclusion in Dissertations and Theses by an authorized administrator of PDXScholar. Please contact us if we can make this document more accessible: pdxscholar@pdx.edu. 
THE DETERMINANTS OF WOMEN'S WORK: A CASE STUDY FROM THREE URBAN LOW-INCOME COMMUNITIES

IN AMMAN, JORDAN

by

TAGHRID KHURI TUBBEH

A dissertation submitted in partial fulfillment of the requirements for the degree of

DOCTOR OF PHILOSOPHY

in

URBAN STUDIES

Portland state University

1994 


\section{DISSERTATION APPROVAL}

The dissertation of Taghrid Khuri Tubbeh for the Doctor of Philosophy in Urban Studies was presented November 4, 1993, and accepted by the dissertation committee.
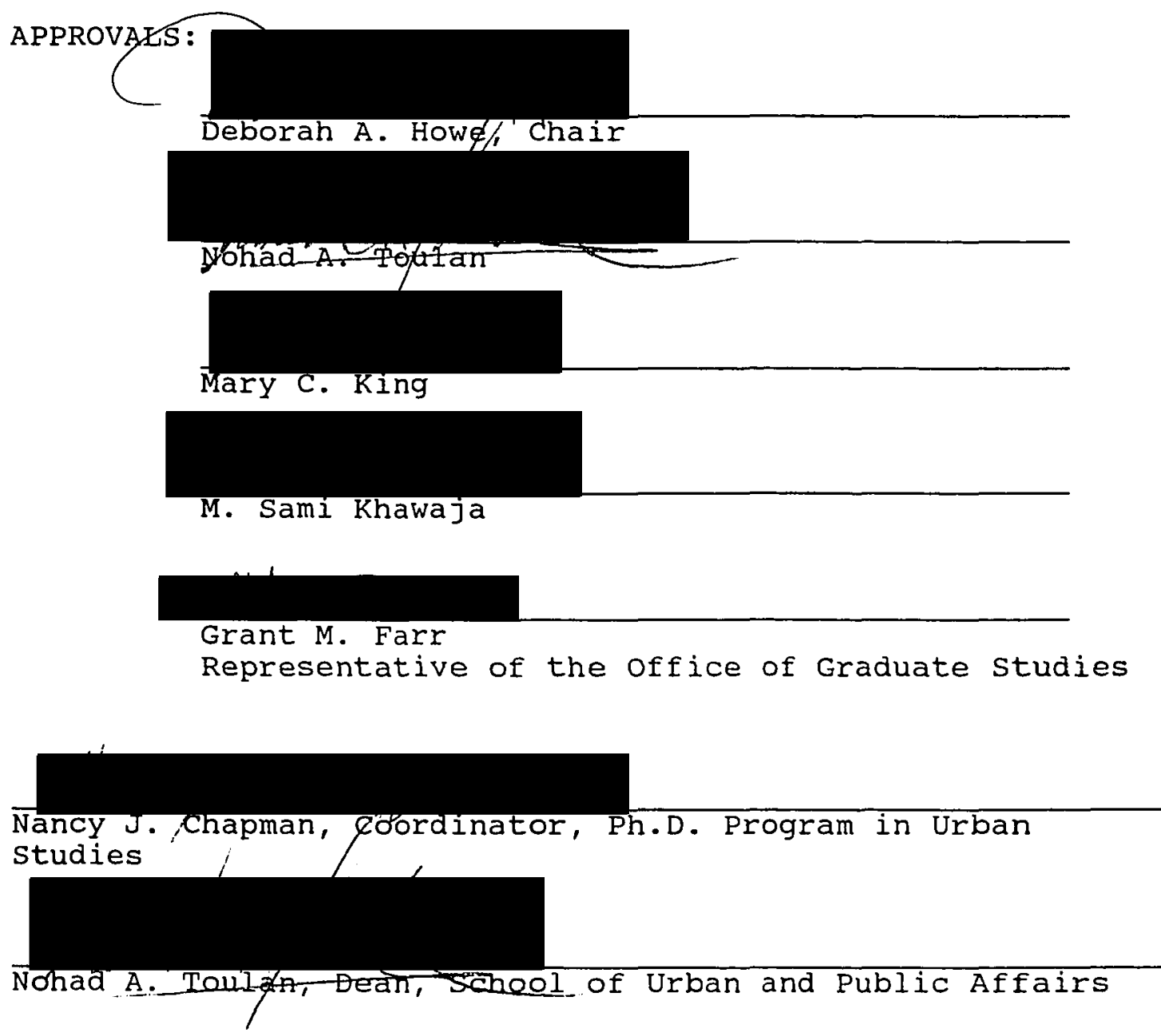

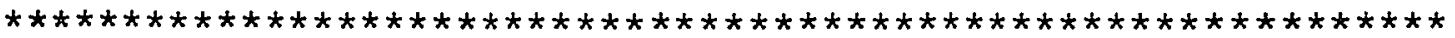

ACCEPTED FOR PORTLAND STATE UNIVERSITY LIBRARY

by

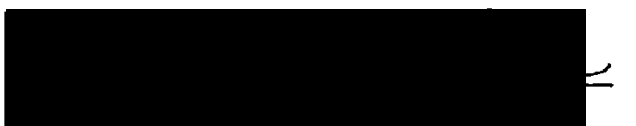

on $2-2-84$ 


\section{ABSTRACT}

An abstract of the dissertation of Taghrid Khuri Tubbeh for the Doctor or Philosophy in Urban Studies presented November $4,1993$.

Title: The Determinants of Women's Work: A Case Study from Three Urban Low-income Communities in Amman, Jordan

This study addresses the determinants of women's economic activity in three low income communities in Amman, the capital of Jordan. These communities represent what is typically referred to as "pockets of urban poverty." Besides addressing the demographic and socio-economic variables, the study identifies and includes cultural variables in a model of female labor force participation. Modern economic systems developed definitions and measurements of productivity that render the majority of women's work as non-productive. Activities within the domestic sphere that do not earn monetary returns are not measured as productive economic activities, and hence are dropped from the calculations of gross national and domestic products of most if not all developing nations. 
In the Arab Middle East, where women's work outside the home is relatively a recent phenomenon, labor statistics are measuring only female labor force in the "formal sector" of the labor market. The scope and magnitude of women's economic activity within the domestic sphere, or in what is termed the informal sector, is neglected, or at best, underestimated, by labor force statistics. In such cultural contexts where women's economic activity outside the home is still considered secondary to the array of their reproductive and home-related activities, the underlying thesis is that cultural factors play an important role in shaping the outcomes of women's decisions regarding labor force participation.

A field survey covered the sample of adult women, aged 15 years and over. To achieve a $95 \%$ level of significance, 435 women were interviewed. Three field surveyors were trained to thoroughly probe and depict all types of economic activity for the purpose of raising cash, be it in the formal or the informal sectors of the labor market.

A nested logit model assesses the effects of demographic and socio-economic variables on women's employment status. Employment status is defined as a dichotomous dependent variable indicating whether a woman does or does not work. The second step of the logit model incorporates cultural variables in addition to the demographic and socio-economic variables. Each logit run 
segregates women by marital status, and one run addresses the pooled sample of women, with marital status included as a predictor variable.

The results indicate that age and marital status (in the pooled sample) are important variables in determining the employment status of women. The presence of a resource person to help the ever-married woman in child-care also had a significant effect on women's employment decisions. Household income, which represents the need for the woman's income, is also a significant variable.

In the second step of the nested logit model, education significantly influences women's work outside the home. Segregation (a cultural variable that represented a constraint to women's work in a mixed environment) is also a significant variable in influencing women's work inside the home.

This study shows that when addressing the determinants of female labor force participation, it is important to include cultural variables and assess their effect on influencing the outcome of women's decisions to undertake economic activity.

Policies that seek to increase female employment need to be aware of the cultural and demographic (fertilityrelated) considerations. Consequently, employment creation and enhancement programs need to be formulated and designed with these consideration in focus. For example, child-care 
facilities could be established within communities. This will free some time of mothers with children to work outside the home, and will create child-care jobs within the community. Realizing that, due to cultural barriers, some women will still desire to only work at home, agencies providing marketing channels for such activities need to be established. 
TO MY PRECIOUS DAUGHTER, DEENA

AND

MY BELOVED HUSBAND, AZMI 


\section{ACKNOWLEDGEMENTS}

I wish to extend my thanks and express my gratitude to the numerous colleagues and friends who helped me complete this work. First, I'd like to start with my committee members: Dr. Deborah Howe, Dr. Nohad Toulan, Dr. Mary King, Dr. M. Sami Khawaja and Dr. Grant Farr. Their invaluable comments and timely feedback, in light of my time constraint, were most appreciated. Special thanks go to Dr. Deborah Howe, committee chair-woman, who spent hours reviewing the various drafts of the dissertation, on weekends and on Thanksgiving day. I am indebted to her for the quality of this final product. My meetings with Dr. Toulan, Dr. King and Dr. Farr were most interesting, and certainly enriched my research. I am also grateful to Dr. Khawaja who helped me tremendously as an advisor and a true friend. I appreciate his assistance in reviewing the analysis results, interpretation of the shazam output and the quality of the methodology. Muhannad, thank you for everything.

I would like to thank Dr. Walt Ellis for sitting in for Dr. Khawaja during the defense. But my thanks to Dr. Ellis and his wonderful wife, Rosemary, extend way beyond that. since my first years at Portland state, they have both been such special, kind, and supportive friends. They were 
always there to pick me up during my several downs in this tedious and lengthy process. Warm wishes also go to Dr. Toulan and Dirce for their support and friendship.

I am thankful to Pati sluys for her patient and meticulous work on correcting and formatting the dissertation. Special thanks go to Mai Kawar who earlier did a most superb job on data entry and validation.

My sincerest gratitude goes to Dr. Barbara Ibrahim and Dr. Huda Zurayk at the Population Council in Egypt. The funding they provided for my field research made the phenomenal expenses of this project tolerable. I am also looking forward to this study getting published as part of the funding they provided. I thank them for their academic input and advice and for their warm friendship.

In Portland, several people made my stay easy and pleasant. Uncle Sami Khouri and his beautiful wife, Helene, welcomed me not only in their home, but also in their hearts. My cousin Siham Khoury, provided me with another home away from home. Siham, I can never thank you enough! Thanks are also extended to her sweet daughters Nadia and Daliah. Noha (KOZ) managed to brighten my dreary moods with her bright chuckles. I enjoyed the times I spent with her and her family. My dear cousin suzy, was also a nice and pleasant friend. My little cousin, Rola, reminded me of my daughter Deena and of how wonderful it is to have a daughter. I am also grateful for my other cousins in 
Portland, Majeed and his wife Julia, Nader and his wife Martha, wael and samer. I am thankful for all those who attended the defense; their presence was most encouraging. Sincere thanks and warm wishes go to Nihad Aweidah, Maha Khawaja and to my two dear friends who never give up on me: Kathi Ketcheson, Sandy Herman and Carla Braam. Thanks are also extended to those who kept me company through their numerous phone calls: Uncle Nabih and family and Nahla and Raouf in California, Dima in Florida, and Ramzi Khuri in Texas.

At the professional level, I am grateful for Judith Bruce at the Population Council in New York, who provided me with tremendous and invaluable research papers on women and development; also for Nancy Gillespie at the World Bank. I'm happy to have made their acquaintance and friendship. Special thanks go to Dr. Leila Bisharat at UNICEF for the time she provided in giving me feedback throughout the various stages of my study, despite her busy schedule and frequent travels. On the personal level, I appreciate the support and enthusiasm I got from her and her husband, Suhail.

In Amman, I'd like to start by thanking the Save the Children Jordan Field office for allowing me to use their 1987 data set. Thanks are due to Dr. Hussain Shakhatreh, at the Ministry of Planning, for lending me research articles from his personal library on "women and work," and also to 
Nadia Takriti and Mary Kawar for interesting and useful discussions on the subject. Dr. Ziad Rifai and Dr. Sima Bahous have supported me with their friendship and academic knowledge and feedback.

Dr. Rima Khalaf Hunaidi always supported me and provided the needed nudge when I let my work slip off my mind and life. Other individuals whose friendship I cherish are Hani, George and Zina, Fuad and Gida, Makram and Basma, Humam and Iman, Fuad and Sireen, Sari and Maha, and Hala. Also, Ghada and Munir, Maha, Rana, Hind and Rima Alamat. Hearty thanks go to my dear mother Emily and father Jamil for their love, endless support and warm wishes. My brothers Mazen and Ramzy have supported me with their love and beautiful thoughts. My love and thanks are due to my dear mother-in-law, Alice. The same goes to those who, in their different ways provided me with their kind support: Nuha and Munir, Vicky and Michel, Maha and Nabil, May and Fuad, Samar, and all the wonderful children in the family.

Last but not least, my love, gratitude and appreciation go to my dear husband, Azmi and my precious daughter, Deena. Their patience with me and their tolerance of my erratic schedule over the last few years were insurmountable. Thank you both so dearly. It was your love and support that kept me going. May God bless you! 
TABLE OF CONTENTS

PAGE

ACKNOWLEDGEMENTS. . . . . . . . . . . . . . . . . . $i i$

LIST OF TABLES. • . . . . . . . . . . . . . . . . . ix

LIST OF FIGURES . . . . . . . . . . . . . . . . . xi

CHAPTER

I INTRODUCTION . . . . . . . . . . . . . . 1

Women in Development . . . . . . . 3

Women in Poverty . . . . . . . . . 7

Women in the Middle East . . . . . . 11

Policy Implications. . . . . . . . 14

Purpose of the Study . . . . . . . 16

II LITERATURE REVIEW. . . . . . . . . . . . . 24

Theoretical and Conceptual Models. . . 24

Empirical studies. . . . . . . . . 34

III FEMALE LABOR FORCE CONCEPTUAL MODEL. . . . . . 42

The Pooled Sample Model. . . . . . 46

Demographic Variables

Socio-Economic Variables

Cultural Variables

Single Women's Conceptual Model. . . 65

Ever-Married Women's Conceptual

Model............. . 66

Currently-Married Women's Model. . . 69

Main Hypotheses. . . . . . . . . 70 
vii

IV DATA AND METHODOLOGY OF THE STUDY. . . . . . . 72

Secondary Data set . . . . . . . 72

study Sample. . . . . . . . . 75

Questionnaire Design and Data

Collection . . . . . . . . . 77

Methodology. . . . . . . . . . 80

Model Specification. . . . . . . . 82

Pooled Sample Model

Single Women Model

Ever-Married Women Model

Currently-Married Women Model

Pooled Sample Model (Including

Cultural Variables)

Variable Definition. . . . . . .

Dependent Variable

Independent Variables

Part I: Respondents' Distribution. . . 91

Employment Distribution by Marital status

Part II: Comparison Between Women and Men in the Sample Population . . 100

Part III: Comparison Between Working and Non-Working Eligible Women . . 105

Part IV: Results of the Multivariate Analysis . . . . . . . . . . 109

The Pooled Sample Logit Model

Single Women Logit Model

Ever-Married Women Logit Model

Currently-Married Women Logit Model

The Pooled Working Women Sample (Including Cultural Variables) 
viii

VI SUMMARY AND CONCLUSIONS. . . . . . . . . 130

Findings . . . . . . . . . . 131

Policy Implications and

Recommendations . . . . . . . 133

Further Research . . . . . . . 140

SELECTED BIBLIOGRAPHY . . . . . . . . . . . . . . . 143 APPENDICES

A JORDAN: A COUNTRY PROFILE. . . . . . . . . 158

B QUESTIONNAIRE. . . . . . . . . . . . 178 


\section{IIST OF TABLES}

I Percentage Distribution of Female Respondents by Age Group and Marital status . . . . . . . . . . 92

II Percentage Distribution of Female Respondents by Education Level $(\mathrm{N}=435)$. . . . . . . . . . . . . 94

III Employment Distribution of the Female Respondents. . . . . . . . . 95

IV Employment Distribution of Female Respondents by Marital status $(\mathrm{N}=435)$. 96

$\mathrm{V}$ Economic Activity of Female Respondents by Marital status $(\mathrm{N}=435)$. . . . . . 97

VI Economic Activity of the Eligible Females by Marital status $(\mathrm{N}=314)$. . . . . . 98

VII Occupational Distribution of Working Women. . 99 VIII Age and Education Comparison. . . . . . . 101

IX Percentage Distribution of Marital Status . . 101

X Employment Status Comparison. . . . . . 102

XI Income Comparison . . . . . . . . . . 103

XII Distribution of Men's Occupations . . . . 104

XIII Difference of Means Analysis (Eligible Women; $\mathrm{N}=314$ )........... 105

XIV Difference of Means Analysis (Ever-Married Women; $\mathrm{N}=208$ )............. 106

XV Difference of Means Analysis (CurrentlyMarried Women; $\mathrm{N}=189$ ) . . . . . . 106

XVI Difference of Means Analysis (Working Women; $\mathrm{N}=132$ ) ........... 107 


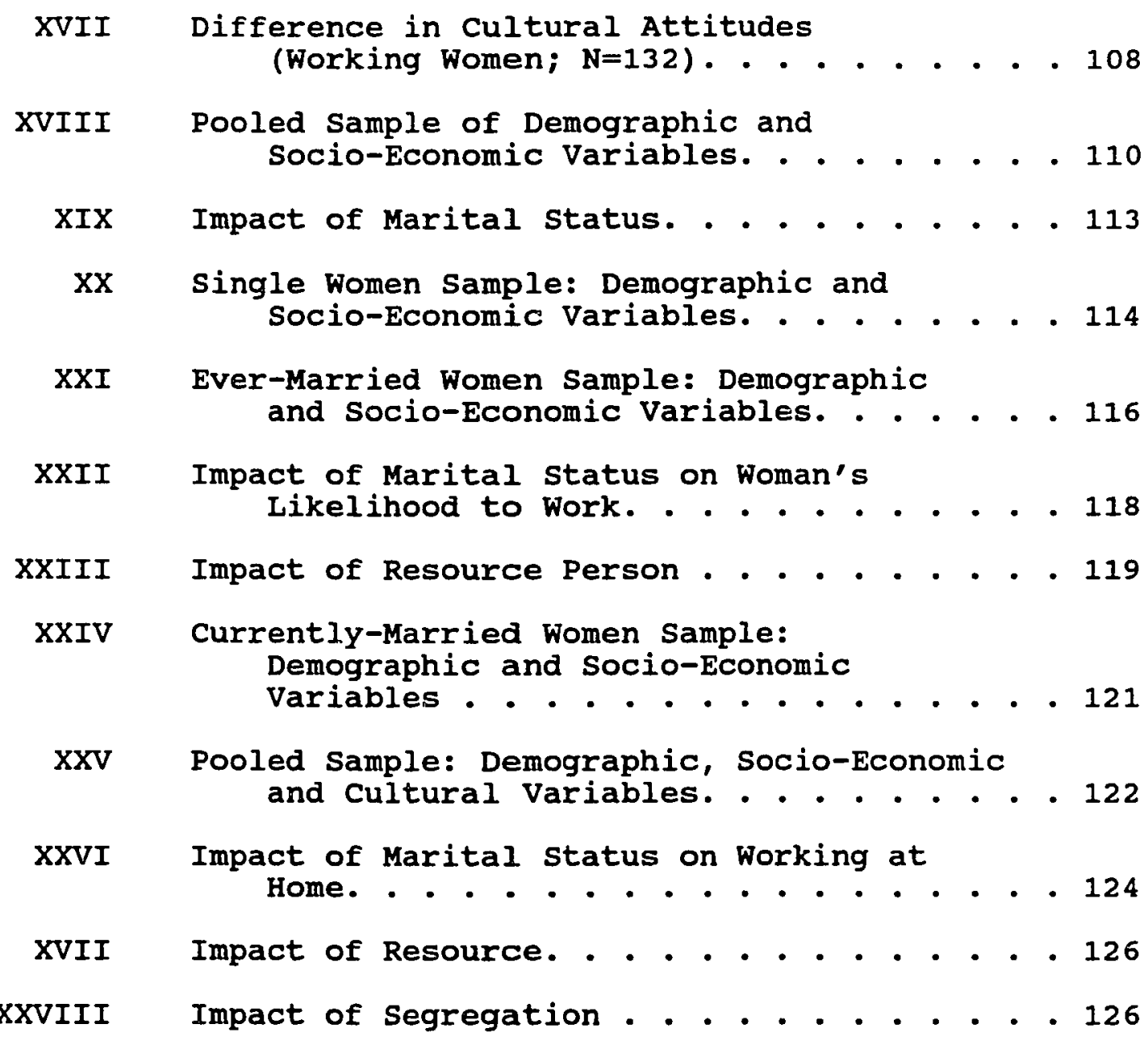




\section{LIST OF FIGURES}

FIGURE

PAGE

1.

The Pooled Sample Model (Demographic and Socio-Economic Variables) . . . 85

2. The Pooled Sample Model (Demographic, Socio-Economic, and Cultural

variables. . . . . . . . . . . 
CHAPTER I

\section{INTRODUCTION}

Over the last two decades interest in the role of women in economic development has increased tremendously. The United Nations Decade for Women (1976-1985) played a crucial part in highlighting and publicizing the important but often invisible role of women in the economic and social development of their countries and communities.

The accelerated growth models which dominated development planning for the first two decades following World War II, aimed to increase overall national economic growth through a policy of accelerated industrialization. By the mid 1960s it was gradually being realized that strategies based on maximizing the Gross National Product (GNP) were neither leading to the desired level of income redistribution nor solving the problems of poverty and unemployment in developing countries (Lipton, 1983). In the 1970s, labor intensive techniques, income redistribution, and provision of basic human needs to the poor gained popularity as keys to development.

The international preoccupation with the macroeconomics of development left governments of developing nations and development agencies ill-prepared for the task 
of obtaining reliable information on poor people's socio-economic conditions. Macro-economic models of development in Third World countries seemed to also ignore the conflicts among various interests in society and how these models affect the existing class structures. However, equality--as called for by the United Nations (1976)--has implied and been put along both class and gender lines.

It seems that the significant under-reporting of women's economic roles has been the result of poor conceptualization and recording of labor force statistics (Elson, 1991; Papps, 1992). Also, the misunderstanding and lack of recognition of women's roles have rendered women as concerns to development planners because of their reproduction and childbearing, instead of participants and contributors to development (Collier, 1989; Moser, 1989). The domestication of women (Rogers, 1980) has emphasized women's functions as homemakers and childbearers, and has overshadowed their role as economic producers (Mies, 1982). Therefore, development policies whose goal is to raise the standard of living, have not utilized women's economic resources. Policy makers have not realized that women's inefficient and under-remunerated economic activities add to the overall grim picture of under-development. Nor have they become aware that increasing women's productivity is crucial to improving this economic picture. Apart from the obvious effect of reducing the productivity gap between the 
sexes, women's involvement in the development process would help accelerate the growth of the economy beyond the rate attainable by the use of male labor alone. The awareness of women's contributions to the development process, both as beneficiaries and participants, is deemed conducive to development of the whole society.

\section{WOMEN IN DEVELOPMENT}

In developed nations, the contribution of women to the work force has been accounted for in terms of output into the economy. However, women's economic activity in developing countries has been confounded with several problems. Patriarchal social structures and a rigid division of labor affected women's home production, labor force participation, wages, economic security and status (Cain, Khanam, \& Nahar, 1979; Kandiyoti, 1988; Mernissi, 1988) - Boserup (1970), whose analysis two decades ago, spawned diverse literature on women and development, historically documented how women's economic roles and Iife opportunities have been influenced by the advent of the development process. Rapid capital intensive development has eliminated certain types of work for women. The shift from traditional to modern economic systems' ${ }^{1}$ has eroded

${ }^{1}$ Traditional activities are viewed as those which existed before, and continue in the face of, western capitalist penetration. Modern activities are viewed as those which result directly from foreign influence and investment, the application of advanced technologies, and the advent of sophisticated professional and governmental activities (Bromley, 1978). 
women's subsistence production roles. This shift has also widened the gap in the levels of knowledge and training between men and women.

Shorter and Zurayk (1985) argue that women's participation is underestimated because the common methods of enumeration often omit seasonal and part-time work. These methods also ignore unpaid family workers on family farms or in small family businesses and do not usually take into account the production which takes place within the household, such as food preservation or the production of clothing (Collins \& Gimines, 1990). The woman's role as a reproductive and childbearing agent has overshadowed her potential contribution to the development process (Collier, 1989; Moser, 1989). The existing data bases misreport women's economic activities (Rao, Anderson, \& Overholt, 1991). Few countries include in their national census specific tabulations on household heads by sex. Even fewer countries cross-tabulate these data by marital status, age, or economic activity. Due to under-reporting of their contribution, women were considered marginal actors in the social and economic transformation that was taking place in their countries (Buvinic, 1976; Rockwell, 1985; UNESCO, 1983) .

Concerns for women have arisen as a result of exposing certain misconceptions. Some of these misconceptions are that men are the principal laborers in their society, they are the heads of households, they are the primary 
breadwinners, and their wages constitute family incomes. other erroneous assumptions are that women and men have equal access to educational opportunities; women's rights are protected within the traditional family unit; and women are extended economic support regardless of whether they are single, married divorced, widowed, or abandoned (Buvinic, 1984; Maguire, 1984; Rihani, 1977). However, the changing economic conditions in developing societies and the actual economic reality in which male and female members of a traditional family unit function became sufficiently powerful to raise questions as to the appropriateness of the ideal family assumption. Male unemployment prevented men from keeping their previously traditional economic obligations toward their kinswomen. Furthermore, internal and international migration have led to the breakdown of the extended family, thus the shift to nuclear families deprived women of their family and social support networks (Bhatt, 1989; Cain et al., 1979; Hoodfar, 1990).

Internal and international migration has also led to a dramatic increase in women-headed households (ISIS, 1986). At the end of the 1970s, the number of female-headed households was estimated to reach up to $48 \%$ of households in the developing countries (Rosenhouse, 1988). A decade of research on women and development has consistently shown that women heading their own households are over-represented among the world's poor households (Buvinic, Youssef, \& von Elm, 1978; Folbre, 1991). Also, the poorer the household, 
the more time women devote to working in low-return activities (Grown \& Sebstad, 1989).

Although the data tend to underestimate women's economic contributions, women's employment in developing countries over the last four decades has increased both absolutely and relatively (Grown \& Sebstad, 1989). Between 1950 and 1985, the proportion of all adult women seeking paid employment grew; so did the female share of the total labor force. In 1950, 37\% of women in developing countries were counted as labor force participants; by 1985, this percentage rose to $42 \%$ (Grown \& Sebstad, 1989). These aggregate numbers do not reflect the enormous variations that exist between regions (Van Ginneken, 1988). Much of the existing literature assumes that increases in female labor force participation are associated with improvements in the position of women. However, although more women are in the labor force, the effect of these trends is by no means entirely positive. Jobs are more static now than in the past (Grown \& Sebstad, 1989; Standing, 1989), and wages have declined to the point where they often cover only individual rather than family subsistence (Ibrahim, 1989). A United Nations (1985) report pointed out that women worldwide do $60 \%$ of the work but earn only $10 \%$ of the wages, and own only $1 \%$ of the world's property. And although no comprehensive data exist on women's earnings, evidence from micro level studies shows a persistent and substantial income gap by sex in both formal 
and informal economic activity (Acker, 1989; Rao et al., 1991).

Moser (1989) argues that development did not necessarily improve conditions for women. In developing countries, particularly in urban areas, women are concentrated heavily in informal sector activities; in general, their representation in the informal sector is higher than their participation rate in the economy as a whole and is increasing (Food and Agriculture organization, 1983). Studies of major cities in Africa and Latin America found that women comprise from $25 \%$ to $40 \%$ of informal sector business owners and operators. Women's informal businesses have lower sales revenues, lower asset bases, and smaller profit margins than men's (Berger, 1985; Liedholm \& Mead, 1987). Papps (1992) adds that

even the cursory knowledge of economic theory makes it clear that increased labor force participation implies gains only if it occurs as a result of an increase in the demand for labor. If, on the other hand, it occurs as a result of an increase in the supply of labor, because of decreased real incomes, then increased labor force participation will be accompanied by decreased real wages and, consequently, decreased wellbeing. (p. 596)

\section{WOMEN IN POVERTY}

The United Nations (1976) called for equality, development and peace. Development is a goal that aspires to improve the well-being of human populations, and the essence of modern economic growth in that, on average, the 
per capita income of all people in a nation rises, not just the income of a select few (Van Ginneken, 1988). However, the term economic development has been used interchangeably with economic growth. Although it is emphasized that the former cannot happen without the latter, economic development still created or enlarged the gap of economic welfare, not only among nations, but often among societies within the same nation. Hence the emergence of the distinctions between developed and developing nations, modern and traditional economies, the north and the south, and the rich and the poor.

A growing concern with poverty has looked into the socio-economic effects of macro-economic restructuring to address the growing disparity between the rich and the poor (Black, 1991). It has become obvious that development of the type experienced by the majority of Third world countries in the last quarter century has meant, for very large numbers of people, increased impoverishment (World Bank, 1990). This highlighted the doubt that economic growth alone may eradicate or even alleviate poverty within reasonable time periods. Contrary to the belief that adoption of growth-oriented development strategies would solve the poverty problem without much difficulty if growth could be accelerated, is a wide spread pessimistic view which argues that the mechanisms which promote economic 
growth also foster economic concentration and aggravate inequality (Collier, 1989; Cornia, Jolly \& Stewart, 1987). While the characteristics of poor health and low education levels of low income households are well recognized, for women, the problems are compounded. Therefore, it becomes equally important to know what is different for women than for the poor in general (Bruce \& Lloyd, 1992; Buvinic \& Rao Gupta, 1992; Engle, 1991; Lloyd \& Brandon, 1991; Merrick \& Schmink, 1983; Rogers, 1991; Rosenhouse, 1988; Youssef \& Hetler, 1983). Women's conditions in poverty, highlighted by high illiteracy rates and poor access to land and food production, have squeezed women out of the traditional spheres of production (Boserup, 1970). At the same time, these conditions have reduced the demand for their labor in wage employment, thus relegating them to low status, irregular and poorly remunerated work in the lower echelons of informal sector activities (Ibrahim, 1989; standing, 1989). Work options are limited because of child care problems and because impoverished women are often too physically depleted and unprepared to compete in the world of work (Blumberg, 1991; Engle, 1980; Varma, 1985).

Although poverty in the developing world is not restricted to female-headed households, the mere size of this group and its disadvantaged position vis-a-vis joint or male-headed households, suggests that these households should receive special attention in social adjustment 
programs. Structural changes in society are impinging on families, forcing stress on poor families and structurally disadvantaging vulnerable groups, mainly women and children (Afshar \& Dennis, 1992; Cornia et al., 1987). As such, these structural inequalities leave women in graver situations.

Many studies that verify and assess women's role in the well-being of their families have been conducted (Blumberg, 1988; Bruce \& Dwyer, 1988; Fernea, 1985; Grown \& Sebstad, 1989; MacLeod, 1992; Rao et al., 1991). These studies further link this role with the overall development of society. Development policies concerned with the alleviation of poverty and improving the status of women are continuously seeking ways to improve the livelihoods of poor women through support for activities that enhance their earnings, whether they are wage earners, self-employed, or engaged in other business activities within or outside the formal economy. However, policy makers, development researchers, and practitioners need to be aware of the already heavy and onerous burdens that women in general, and poor women in particular have to bear, that would challenge their ability to respond to specific development policies (Hoodfar, 1990; Rao et al., 1991). 
WOMEN IN THE MIDDLE EAST

Women's labor force participation varies among countries and within regions. It is estimated that the female labor force participation rates in the 1970s, in many Asian, Latin American, and sub-Saharan African countries, were close to that of many industrialized countries (Youssef, 1974). In contrast, the participation rate of women in the Arab Middle East, at 11.4\%, was the lowest of any region in the world (Hijab, 1988). In a comparison of some Middle Eastern Muslim countries and Latin American countries at the same level of economic development, Youssef (1974) finds that the level of female labor force participation in non-agricultural activities in the modern sector does not respond in a uniform way to the level of development. She argued that for neither region did economic variables such as the level of development and demand for workers effectively influence the size of the female work force. Instead, social factors such as increased education opportunities and a wider range of alternative roles for women led to increased female employment.

To explain Arab women's low labor force participation rates, many writers on the Middle East automatically focus on Islam and on religiously-inspired cultural attitudes. They maintain that the conservative nature of Islam is responsible for holding women back. Beck and Keddie (1978) 
point out that Islamic society has been more conservative in maintaining old laws and traditions than other societies.

Hijab (1988) asserts that "blaming Islam" for keeping women out of the modern sector ignores that many such attitudes towards women are shared worldwide; the position of women in the Arab world is not unique.

Women around the world are still considered to be an underprivileged group and many of the obstacles they face are the same: deeply rooted traditions, lack of finance to improve their conditions, and the lack of political will to change the situation." (Hijab, 1988, p. 2)

The national plans and development programs of the Arab countries affirm that human beings, both men and women, are the ultimate objective of development pursuits. The Declaration of Social Action of the Arab States, issued in 1971, asserted, among its fundamental principles, that men and women are partners in life and destiny, and they must work together to build a life based on cooperation and equality. All countries in the region have realized the necessity of increasing the capacities of women, both as a goal for and a means of development, to enable them to play a more active role in the building of society as equals to men. However, Hijab (1988) argues that while the declarations sound laudable, the actual extent to which they could be implemented is circumscribed by several problems. Economic and social planning in most countries of the region lack data and studies upon which decision making and program planning depend. The shortage of statistics and studies 
concerned with the situation of women reflects a kind of discrimination against them. For example, national accounts do not take into consideration the economic activities of housewives (Anker, 1984; Shorter \& Zurayk, 1985). Employment statistics consider the majority of women as outside the labor force and not seeking work (Bose \& Rossi, 1983). There is no accurate data over periods of time to enable the formation of statistical indicators concerned with women's living conditions, levels of health, life expectancy, literacy, nutrition, and other social indicators.

Another problem, Hijab (1988) adds, is that the Arab region is the only one to stress its cultural heritage as a fundamental principle of its development framework. Several constitutions stress the importance of the Arab family as the basic nucleus for the development of society, and that women are deemed to be the key to maintaining the traditional family unit. However, the Arab world is a society in transition. Hijab (1988) argues that resistance to change in anything that concerns the family is most pronounced in the Arab world, although it is unrealistic to believe that there can be change in the political and economic interactions of society without change in social relations. The question of changing women's roles lies at the base of the intricate pyramid of problems that the Arab world is seeking to solve. The role of women in 
society--whether they should be part of the work force as equal partners to men, or stay at home to rear the family, remains one of the major issues that the Arab world has yet to resolve.

Hijab (1988) emphasizes that, of all members of society, women suffer the most from the tensions of the transitional phase. When the dimensions of poverty and culture are added to the consideration of women's circumstances in developing nations, and particularly in the Arab Middle East, it becomes crucial to investigate the scope of women's livelihood activities.

\section{POLICY IMPLICATIONS}

Recent schools of thought started to explore household survival strategies (Bruce \& Dwyer, 1988; Grown \& Sebstad, 1989). Interest arose as to how impoverished households manage to continue to survive at the subsistence level. Evidence accumulated by international organizations during the last decade highlighted the crucial role played by mothers in children's survival (Bruce \& Dwyer, 1988; Engle, 1980; Moser, 1989). It emphasizes that women's earned income and their ability to stretch it and other resources available to them is vital to the survival of their households. Women are viewed as strategic actors, whether they are conscious of this role or not, in defending their 
own life prospects and extending those of their children (Bruce \& Dwyer, 1988).

Bruce and Dwyer (1988) contend that

just as men and women differ in their labor market participation, wage rates, and in their prospects when marriages dissolve through death and separation, men and women also frequently differ with respect to their allocational priorities. A central impetus to women's earning, which is attaining a better life for their children, may explain the allocational priorities they apply to their own income and other income under their control. (p. 2)

Several articles from various parts of the world present a considerable body of information that has been built up on the subject. These studies and project evaluations strongly indicate a greater devotion of women's than men's income to everyday subsistence and nutrition (Bruce \& Dwyer, 1988; Rao et al., 1991).

A direct relationship has been established between expanded opportunities for women and improved health and learning for children. The premise is that with improved income opportunities, coupled with targeted substantive education and training, females, and especially mothers, will be better able to improve the quality of their households' well-being. Thus governments with constrained resources are better able to relax their subsidies on subsistence outlays. Women's roles as daily financial managers of the household and as primary guardians for the physical and social status of their children, should be 
viewed as important ingredients in the development process, at least at the micro household level (Bruce \& Dwyer, 1988). Since women constitute half the population of most developing nations, the understanding of why women do or do not engage in earning activities could enhance the planning capacity of governments and promote appropriate shifts in designing income earning activities, thus enhancing the productive capacity of latent and underutilized resources. A bottom-up (micro to macro) understanding of the economic incentives (and disincentives) helps foster further analyses of women's contributions and provide leads to appropriate development planning and implementation.

Thus it is crucial for the policy maker to see the link between women's roles and the performance of the economy at the macro level. As a result of such analyses and congruent policies, the national economy will reap long-term economic development benefits.

PURPOSE OF THE STUDY

Sociological studies of Arab women in education, employment, and national development began to proliferate in the 1970s, but these were largely based on government census data or unstandardized national sample surveys. The measurement of female labor force activity in the Arab world was often under-reported, and the data that did exist, were either inaccurate or incomplete (Hijab, 1988). 
Studies that do exist on female labor participation, on one hand, only address women's economic activity in the formal sector of the labor market. They address the demographic and socio-economic variables of the economically active females. Hence they miss out on the considerations (obstacles and constraints) of those females who are not economically active. On the other hand, data pertaining to women's activities in the informal sector, that may comprise a substantial part of female economic activity, are virtually non-existent.

Much confusion has resulted from the various attempts to define the informal sector (IIO, 1991). The informal sector was first introduced by Hart in a study on Ghana in 1971. The formal/informal dualism was ratified by the International Labor organization in 1972 (ILO, 1972) and was subsequently used by analysts of urban employment in the Third world. The two-sector terminology divided the economy into "informal" (an extension of the concept of "traditional") and "formal" (more-or-less analogous to "modern") sectors. It emphasized the significance of selfemployment and small enterprises and the degree of statistical under-recording in the informal sector. It was often regarded as synonymous with the urban poor or the working poor (Moser, 1978). Bromley (1978) summarized the distinctions between the informal and formal sectors in their crudest form as follows. 
Informal activities are a way of doing things, characterized by ease of entry; reliance on indigenous resources; family ownership of enterprises; small scale of operation; labor-intensive and adapted technology; skills acquired outside the formal school system; and unregulated and competitive markets. The characteristics of formal sector activities are the obverse of these, namely, difficult entry; frequent reliance on overseas resources; corporate ownership; large scale of operation; capitalintensive and often imported technology; formally acquired skills, often expatriate; and protected markets through tariffs, quotas and trade licenses.

This research addresses the determinants of women's economic activity in three low-income urban communities in Amman, the capital of Jordan, in both the formal and informal sectors of the labor market. It is worth noting here that it is beyond the scope of this study to make conclusions about the informal sector, and the proportion of women engaged in economic activity therein, since it is only a case study. However, it is hoped that it will serve as an eye-opener to the policy maker in Jordan. It should serve as a first step towards the understanding of the conditions and life circumstances of poor women who manage to find a means of livelihood in the informal sector.

This study attempts to identify and investigate the factors that determine women's propensity to work. It 
examines the various factors that operate and interact to determine why women do or do not engage in market or home production for the purpose of raising cash. Hence, it looks into what constitutes motives and incentives for women to undertake economic activity. On the other hand, it also examines the obstacles and constraints that prohibit or undermine women's involvement in income earning activities. Women's low participation rates could be a reflection of either a constrained labor market or high fertility rates that reflect competing claims on their time. Low participation rates could also be a reflection of the lack of appropriate jobs that are compatible with their living conditions. Certain cultural and social norms could check women's economic participation, whereby women are, for example, overtly prohibited by the husband or other family members from working.

Poverty is a central dimension in this study. The assumption is that women, and especially those in poor households, want to work to improve their situations and those of their families. Hence it is anticipated that need is the primary motivation for poor women to undertake economic activity.

The main hypotheses this study is attempting to investigate are:

1. The main determinant of women labor force participation is economic need; and 
2. Culture plays an important role in the way women participate in the labor force.

Knowledge of these factors helps promote the understanding of the major determinants that motivate women to work, and disincentives that prohibit or limit their involvement in economic activity.

Jordan is a developing nation with a population of approximately $3.5 \mathrm{million}$. It is mostly desert and has few natural resources. It has achieved satisfactory economic growth rates over the last few decades. This growth was possible mainly by the trickle-down effect of the oil boom in the neighboring Gulf states. Another factor was international financial assistance. It has achieved a fairly advanced infrastructure, and basic services for its population in health, education, and employment. (For a detailed description of Jordan, see Appendix A.)

However, the downturn in the international economy in the early 1980s has hit Jordan, and its adverse effects were clearly pronounced in higher inflation rates and rising unemployment. Those effects were confounded by the demographic problems that existed already. A natural population growth rate of $3.8 \%$, in 1987 , is one of the highest in the world and half the population are under 15 years of age (Department of statistics, 1987a).

The phenomenal episode of boom and recession has had certain important implications for the income distribution 
within the country. Two inequality studies were conducted in $1988 .^{2}$ The findings showed that the richer urban areas were more inegalitarian than the poorer ones. The regional breakdown of undernutrition was quite striking. Roughly one fifth to a quarter of Jordan's population was not receiving sufficient energy intake. An urban resident was twice as likely to be undernourished than a rural one. To the extent that one may think of poverty as undernutrition, poverty in Jordan is mostly an urban phenomenon (Share', 1988).

The most recent blow to Jordan and its development process has been the Gulf crisis of 1990. It profoundly and permanently altered the country's political, social, and economic make-up. A sudden $10 \%$ increase in its population has placed an enormous burden on the country's social services sector and the already ailing economy. A socio-economic profile of the returnee families carried out by UNICEF in December 1990, found that $44 \%$ are under the age of $15,83 \%$ of the returnee labor force is unemployed, and $33 \%$ are below the poverty line.

The communities of Natheef, Mahatta, and Musdar were selected for this study because they represent what is typically defined as pockets of urban poverty (see map of

\footnotetext{
${ }^{2}$ Both studies relied on the only two existing nationally representative budget surveys in Jordan for 1980 and 1986 (Department of Statistics, 1980, 1986). The analysis was also supplemented by the findings of the unpublished study by Assaf (1979) for the year 1973, which was based on household-level data.
} 
Greater Amman Municipality in Appendix A). They are among the poorest communities in Amman (Municipality of Amman, $1979,1993)$.

Save the Children Federation (SCF), an American development organization, provided five year funding (1986-1991) for a development assistance program in the three communities. The program aimed at augmenting the productive capacity and improving the living conditions through a skills transfer strategy: training, technical assistance, and credit. It followed a Women in Development model, whereby women are the primary target for this development intervention. It also had a health service component that follows the UNICEF "child survival and health education" strategy.

A questionnaire was developed by SCF and was approved by the Ministry of Social Development. The baseline survey was carried out between september and December of 1987 . It covered demographic and socio-economic indicators for each member of the target communities, divided by household. For adult members, the data set included education level, employment status, type and regularity of employment, and income.

The questionnaire covered several other areas, including tenure and house ownership/rent; availability of amenities; availability of machines in the home pertaining to income-generation such as sewing, knitting, or leather 
skiving machines; and access to credit and credit history. Two other sections in the questionnaire pertained to the health status of women in the reproductive age, and to children's health and nutritional status under the age of five.

The analysis of the Save the Children data set gave insights and provided leads to the current research. Relevant information from this data set is provided in Chapter IV which focuses on the survey methodology. 
CHAPTER II

\section{IITERATURE REVIEW}

This chapter presents the theoretical framework for the analysis of female labor force participation. It considers the various theories that address labor force participation, with emphasis on female labor models. It reviews some of the relevant research on the factors believed to influence women's participation in economic activity in developing countries. It also presents empirical studies that address the determinants of female labor force participation. In particular, special attention is given to those studies which discuss women's labor force participation in the Arab world. The goal is to understand which factors influence women's decisions to undertake economic activity and the obstacles that prevent them from participating in economic activity. The various demographic, socio-economic and cultural variables are discussed in Chapter III. This discussion will be used in developing the conceptual model that frames this study.

\section{THEORETICAL AND CONCEPTUAL MODELS}

Neoclassical economic theory was the basis of most labor supply models. Mincer (1962) was the first to present 
the neoclassical theory of labor supply, and he derived it from traditional utility maximization concepts. This theory implies that an individual maximizes his/her utility through a rational distribution of time between wage employment and leisure (Bowen \& Finegan, 1969; Cain, 1966). Accordingly, the wage rate determines the individual supply of labor, subject to constraints of time and leisure (Killingsworth, 1983; Standing, 1978). Hence, the labor supply model of females hypothesizes that growth in real wages for women would be expected to increase female labor supply. If wages improve for women or if income opportunities emerge, their labor force participation will be greatly enhanced (Mincer, 1962).

Some authors argue that this theory of women's decisions about labor force participation is unsuitable to non-industrial societies because it ignores women's nonmarket production of goods and services (Steel \& Campbell, 1982; Tovo, 1984). Folbre (1986) emphasizes that householdrelated production (e.g., production for use, production for exchange, and childrearing) is at the core of economic theory.

Mincer (1962), Becker (1965), and Cain (1966) recognize the problem of ignoring women's non-market production. As a result, Becker (1965) introduced a theory on the allocation of time in which the concept of non-market work was incorporated into the theory of labor supply. His model 
includes home production as well as market work and leisure. Nevertheless, in almost all discussions of Becker's time allocation model, the reference to leisure time is replaced by the term "non-market" work, which includes both leisure time and non-market production (Becker, 1965).

The neoclassical theory of labor supply has been criticized by many sociologists and demographers as well as by some economists (Leibenstein cited in Shakhatreh, 1990; Oppenheimer, 1982; Tovo, 1984). The criticism came about because the various theories and household models view the household as a unit. The conventional neoclassical version subsumes the interests of individual family members within a joint utility function: the conventional Marxian version treats the family as though it were a miniature utopian socialist society, untroubled by internal conflict. These theories and household models fail to acknowledge the intrahousehold negotiations over assets and the inequalities within households (Bruce \& Dwyer, 1988).

Oppenheimer (1982) summarizes her criticism of the neoclassical labor supply theory under three points. First, she criticizes the static nature of many micro-economic models that are based on the unrealistic assumption that individuals make most of their decisions simultaneously at the time of marriage, and never change them subsequently. Second, she challenges the monolithic character of the family which is presumed under one-time utility-maximizing 
model. Third, she rejects the assumption that tastes are similar and consistent among people or that they vary randomly over time and among people at one point in time.

A number of critics, motivated in part by feminist concerns, argue that it is inconsistent and arbitrary to assume that households sit completely on one side of a boundary between altruism and self interest. Gender-aware approaches are concerned with the manner in which relationships between men and women and between the different family members are socially constructed (Folbre, 1984). Jelin (1982) emphasizes that households have an internal system of exchange, which entails both shared interests and internal conflicts. Moser (1989) adds that men and women play different roles and therefore often have different needs. Folbre (1986) argues that because major differences in bargaining power derive from objective differences in the economic positions of men, women, and children outside the family, this approach leads rather inevitably towards the need for a more structural analysis of patriarchal inequalities. Significant differences between the economic position of men, women and children within the patriarchal household mean that it cannot be treated as an undifferentiated unit of analysis. Instead, micro-economic analysis of the household must be situated within a larger structural analysis of gender and age-based inequalities (Blumberg, 1991). 
Thus the original focus of neoclassical labor supply theory on individual utility maximization was modified to take into account the family as the unit of analysis. Although in itself the household is not theoretically meaningful, Folbre (1986) argues that it can be analytically useful; it constitutes both an intermediate level of analysis as well as a convenient unit for the collection of empirical data. This modification allows for the possible interdependency of family members' decisions about labor supply. In this new approach, female labor supply depends on other family income in addition to the woman's own wage offer.

The opportunity cost model is another popular model among neoclassical economists. This model looks into the relationships between education and female economic activity, on the one hand, and fertility and economic behavior, on the other hand. Education is viewed as an investment and thus is positively correlated with earning potential. As a result, incentives to seek work are raised. For this reason, educational attainment has often been included as a positive taste variable in econometric models to explain and predict the changing levels of male and female labor force participation (Standing, 1978).

Inferences based on this neoclassical economic approach are consistent with the more sociologically-oriented concept of role conflict described by stycos and Weller (1967). In 
short, role conflict corresponds to the assumption of no joint production of market and non-market commodities. The conflict is equivalent to incorporation of the opportunity cost of women's time in reproductive decision making. Where labor force activity is incompatible with child care, increased participation in the labor market--and corresponding increased opportunity cost of a woman's time-implies decreased fertility. Similarly, increased fertility implies decreased work outside the home. This suggests a useful cohesion of the economic and sociologic perspectives on labor force behavior and fertility (Levine \& Wong, 1989). From this theoretical framework, the cost of a woman's time --usually represented by her potential market wage-represents the opportunity cost of children. While the neoclassical view of fertility behavior predicts a strong inverse relationship between fertility and labor force participation, empirically the causal relationship between work and fertility remains far from clear (Shorter \& Zurayk, 1985; Standing, 1978). Furthermore, Levine and Wong (1989) point out that in developing countries this picture is blurred by the fact that women often are able to share childrearing with other female relatives or domestic servants.

Along the same lines, Oppenheimer (1982) offers what she calls a "social demographic theory" to explain the increase in female labor force participation and decrease in 
fertility in the United states. She contends that the change over time in the proportion of married women choosing to work is essentially a matter of changing tastes for paid employment. She also suggests that economic squeezes are a major factor behind the change in tastes for paid employment. She defines economic squeeze as an imbalance between life aspirations, the market cost of these aspirations and the economic resources available to the household, other than the wife's income. This is very similar to the argument of Easterlin (1980) that the decline in fertility and increase in female employment during the 1960 s and 1970 s resulted from an effort by the younger generation to improve their standard of living in accordance with rising expectations and decreasing relative incomes for the young.

Oppenheimer's (1982) theoretical framework seems to be well-fitted to explaining female labor force participation in developing countries, particularly Middle Eastern countries. However, it has two main problems. First, although she claims that her theory takes into account the social and cultural factors, the data she used to test her model did not contain any of these factors. Second, her model is restricted to married women, hence it cannot, as it stands, be used to examine the labor force participation of females at large. 
Levine and wong (1989) present a theoretical framework that is relevant to the urban setting of developing countries, since it recognizes the complex interactions between the demographic and economic phenomena, and addresses the dynamics of household formation, reproductive behavior and women's labor force participation. Their theoretical framework is based on that used by schultz (1978) and previously presented by Mincer (1962) and Cain (1966). In their adaptation of Schultz's model they assume that the household decision regarding a woman's labor market participation is determined by her market wage offer and other individual characteristics not affecting her market wage. They include household structure as a determinant in their model. Decisions about labor force participation may condition household formation and maintenance. Their model posits that women's employment is determined by the relative values of market and non-market time, constrained by the household budget. A woman's education and experience determines the opportunity value of market time, while young children increase the opportunity value of a mother's time inside the home. In such formulation, the effect of alternative child care availability on labor supply is attributed to a decrease in the opportunity value of a woman's time in the home when young children are present. Relatives or others may be brought into the household to allow mothers to seek outside employment. 
The various theoretical and conceptual models discussed above address the determinants of female labor force participation from both the supply and demand sides of the equation. In general, the supply of labor is determined by the demographic and socio-economic factors of the participants. Age and education are among the major factors that shape the structure of the labor force. Household income determines the need of the labor force participant for income. Other demographic factors also have an important influence. These are primarily bound by the life cycle of the woman, as it relates to her fertility behavior, and to the family size which determines the need for the woman's income.

other factors, especially those that affect women in developing nations at large, and those that are of particular significance to Middle Eastern women, are important determinants. These relate to opportunities that are considered conducive for women to seek employment, such as the availability of a substitute resource person for child care in the case of the married woman with children. Culture may also be of particular significance. Social attitudes and sanctions observed between kin that, for example, advocate family reproduction over economic advantage, may constitute additional barriers to women seeking employment. Cultural settings that restrict women's mobility and choice of occupation are equally important in 
determining the outcome of women's labor force participation.

The demand for labor is determined by various factors, such as the national and regional unemployment rates, wage rates, and employers' preference. It has been documented around the world that female wage rates are lower than those of men for similar occupations (Berger, 1985; Grown \& Sebstad, 1989; Stone, 1983; Liedholm \& Mead, 1987). In the Middle East, employers' preference for male over female employment has been substantiated (Abu Nasr, 1985; Hijab, 1988). This preference has been justified on the basis of women's interrupted work episodes due to childbearing and childrearing.

Discrimination against women has also been based on the erroneous assumption that women do not need to work as much as men (Bose \& Rossi, 1983). However, it has been demonstrated that women want to work more than they are able (Bruce \& Dwyer, 1988; Folbre, 1986; Hijab, 1988; Youssef, 1982). Their ability to work is constrained by various factors and conditions such as childbearing, the primary responsibility of child care, lower education levels, lower mobility and access to employment opportunities.

The discrimination theory, out of the field of sociology, postulates that the removal of discrimination against women and the achievement of equal rights with respect to employment opportunities has strong positive 
effects on the rates of female economic activities (Bose \& Rossi, 1983). Sexual norms which define the place of women and men inside and outside the household and the forces of discrimination in the labor market shape the outcome of female economic roles (United Nations, 1985).

\section{EMPIRICAL STUDIES}

Having reviewed the conceptual literature that frames studies of female labor force participation, we now turn to an in-depth consideration of five empirical studies that provide the analytical framework for this study.

- Levine and Wong (1989). "Household Structure in Urban Mexico: Accommodating Work and Child Care."

- Anker and Knowles (1978). "The Micro-analysis of Female Labor Force Participation in Kenya."

- Steel and Campbell (1982). "Women's employment and Development: A conceptual framework applied to Ghana."

- Shakhatreh (1990). "The determinants of female labor force participation in Jordan."

- Chekaibe (1990). "The Determinants of Female Labor Force Participation in Beirut."

The study of Levine and Wong (1989) examines the relationship between urban mothers' labor force participation and household structure. In their model, they assume that the household decision regarding a woman's labor 
market participation is determined by her market-wage offer, other individual characteristics, and the household structure. The individual characteristics determine the value of the woman's non-market time (those not influencing her market wage offer) namely recent fertility and her husband's level of education. Level of education is a proxy for income. Household structure is used to capture the concept of availability of "mother substitutes," measuring this by the presence of at least one additional woman in the household who is older than 13 years. The age of the woman was also included to reflect the stage of the life cycle of the household.

Their analysis involves the use of a series of regression estimation through standard maximum likelihood methods, as well as discrete choice models (probit). They explored the possibility of household structure being endogenous to the labor force participation of women. They found that both the labor demand and labor supply factors were significant determinants of women's labor force participation. However, the findings did not support the hypothesis that households are being structured to accommodate the possibility of work for mothers.

According to Anker and Knowles (1978), cultural factors play an important role in shaping a woman's decision regarding her participation in the work force. To capture the effect of cultural factors on women's work in Kenya, 
they used binary variables for Muslim women, women whose husbands are living away, and wives of polygamous men. Because of regional variations in women's participation levels between rural and urban women, they ran separate analyses for each group.

Steel and Campbell (1982) criticize the neoclassical female labor supply models for their neglect of cultural and traditional norms. They argue that less attention has been paid to sexism as it affects supply through socio-cultural traditions and demand through discrimination. They emphasize that female supply is affected by social and cultural norms, just as much as it is affected by demographic and socio-economic factors.

Both studies encompass the three main groups of factors which affect female labor force participation: cultural, demographic and socio-economic. However, Anker and Knowles' (1978) framework is more comprehensive and detailed. In respect to demographic factors, they used six variables that are believed to influence women's labor force participation. These variables were: age, marital status, child care burden, presence in the household of women aged 15 years or above, migration, and family size measured in adult consumer units. For the socio-economic variables, they used education, health factors and residence.

The two studies that address female labor force participation in Middle Eastern countries and include 
cultural variables were those carried out by shakhatreh (1990) in Jordan and Chekaibe (1990) in Beirut, Lebanon. Shakhatreh (1990) relies on the empirical studies of Anker and Knowles (1978) and steel and Campbell (1982) to guide the analytical framework of his research. Besides using the demographic and socio-economic variables, he uses religion as a proxy variable for culture. Another dimension of Chekaibe's (1990) study is women's attitudes towards their social role. She uses correlation and cross-tabulation to test the effect of the standard demographic and socioeconomic variables on women's participation in economic activity.

In summary, women's labor force participation is determined by several factors that simultaneously interplay to shape the outcome of women's decisions. While demographic and socio-economic factors are traditionally considered important explanatory variables in discussing and analyzing female labor force participation, cultural and social factors are believed to play an equally important part. This study considers the various theoretical models to arrive at a conceptual framework that is relevant to the study of female labor force participation in urban Jordan. It addresses the demographic, socio-economic as well as the cultural factors that are believed to be major determinants of a female labor force participation model but have not been adequately addressed by previous studies. 
The conceptual framework of the current study builds on the theoretical frameworks and empirical studies discussed above, and makes particular reference to each where applicable. However, it is important to highlight here how this research differs in its emphasis on three dimensions that are considered critical to the study of female labor force participation.

First, studies that address female labor force participation have been done at the national level and cover women's work in the formal sector of the labor market. Most, if not all of these studies rely on national statistics and labor force tabulations. These statistics enumerate participants in the formal (synonymously termed the organized) sector of the labor market. Thus they fail to consider the extent and scope of women's activities in the informal sector.

While it is intrinsically difficult to draw distinctions between the formal and the informal sectors, due to a great deal of overlap (Ibrahim, 1989; ILO, 1991), such definitions do not capture the entire scope of economic activity. Furthermore, in developing nations in particular, no attempts have been made at the national level to define and identify the informal sector, the nature and magnitude of the economic activities therein, nor the characteristics of the participants in that sector. 
The Women in Development literature highlights the fact that this sector provides a source of livelihood for certain segments of the population, more than national governments usually appreciate (Grown \& Sebstad, 1989; Hoodfar, 1990). It also emphasizes that the poor in general and poor women in particular concentrate in the informal sector (Grown \& Sebstad, 1989).

Therefore the thrust of this study is to investigate women's labor force participation based on a wide definition that captures the entire scope of economic activity for monetary returns. It focuses on a wide range of economic activity, be it in the formal or the informal sectors, and whether it is carried out in the home, the immediate community, or in the formal labor market.

The second point of departure is that this is a case study that specifically addresses women's labor force participation in urban poor communities. Investigating work circumstances of women in poverty is of paramount importance to the understanding of livelihood mechanisms of poor households and to women's economic conditions therein. It is the contention of this study that poverty has a structural idiosyncracy that is of particular significance in determining women's labor force participation. In other words, a woman's decision regarding employment is assumed to have a different outcome for a poor woman from one with greater means. 
Much of the literature that addresses poverty

emphasizes that conditions of poor people are different from those of the general population (Buvinic, 1990; Buvinic \& Rao Gupta, 1992; Buvinic et al., 1983; Elson, 1991; Lloyd \& Brandon, 1991; Lolo, 1992; Rosenhouse, 1988; World Bank, 1990). The sociologically-oriented human capital theory points out that individual attributes such as education and experience have a positive influence on a person's labor force opportunities. Since the poor in general, and poor women in particular, have lower education rates than the average population (Bruce \& Dwyer, 1988), this factor alone can serve to demonstrate the constraint of the human capital potential of the poor. Another constraint that is believed to be of particular relevance to the poor, among others, is access to sources of information as they relate to employment opportunities (Anker \& Hein, 1986).

The third departure and contribution of this study is the conceptualization and operationalization of the cultural factors. The cultural variables identified and incorporated in the models of female labor force participation by Anker and Knowles (1978), steel and Campbell (1982) and Chekaibe (1990) are discussed in Chapter III. Shakhatreh's (1990) study in Jordan is particularly relevant here since it addresses women's work in the same socio-cultural context.

Shakhatreh (1990) uses religion as the proxy for cultural variables. While religion implies a composite of 
cultural attitudes and social norms, the variable as depicted differentiates women's participation rates due to their religious affiliation. It did not necessarily capture the women's attitudes and beliefs and how these shape their decisions regarding labor force participation. In contrast, this study will define four variables that depict cultural values and social norms as iterated firsthand by the survey respondents. 
CHAPTER III

FEMALE IABOR FORCE CONCEPTUAL MODEL

This chapter presents the conceptual framework for this analysis. The object of this study is to explore and investigate the nature and magnitude of the factors that are believed to influence female labor force participation specifically for those living at or below the poverty line in urban Jordan. The basis for this study is a series of in-depth interviews conducted among low-income households. The specific structure of these interviews will be discussed in chapter IV. What will be addressed here is the rationale for focusing on poverty, the basis for detecting "economic activity," the structure for considering four distinct models based on the marital status of women and the discrete variables that will be considered for each model.

Poverty is at the core of many theoretical arguments among sociologists, anthropologists, and economists. There is general agreement among the researchers in the field of development, that the phenomenon of poverty is growing in extent and, at the same time, getting more complex (Lolo, 1992). Rockwell (1985) contends that in the world at large women enter the work force primarily out of economic necessity. In the Middle East, where societal stigmas 
discourage women from entering the labor market, women who work in wage labor are often among the poorest members of society. Therefore it is important to look into the context of poverty. Poverty has a crucial bearing on shaping the outcome of women's work decisions.

In defining labor force participation, the United Nations (1985) recommends classifying the population as those who are economically active and those who are inactive. The economically active are gainfully employed, or are not currently working but are seeking employment. In contrast, the rest of the population is classified as economically inactive. This includes housewives, pensioners, students and any other groups receiving private or public support without engaging in economic activity.

Precise definitions of the labor force are difficult, and almost always open to controversy since the activities performed by individuals rarely conform to convenient categories. Moreover, Jelin (1982) emphasizes the importance of a reconceptualization of "work" and "non-work," especially when it comes to low-income women. Although low-income women are not necessarily confined to informal sector activities, statistics from the various developing nations have consistently shown that they concentrate therein (Grown \& Sebstad, 1989; Standing, 1989). The analysis of the baseline survey (Save the Children, 1987) of the population of the low-income communities under 
investigation has shown that $69 \%$ of the women who work engage in informal sector activities. The majority (71.5\%) of the adult female population identify themselves as housewives, although some of them report income. Hence for this study, work entails any economic activity a person engages in for the purpose of raising cash. Work covers all types of economic activity, be it in the formal or the informal sector (including work carried out in or outside the home). Domestic labor is excluded from the definition since it does not entail monetary returns.

Formal sector jobs are usually clearly defined, whether they are full-time, part-time, or daily wage labor. Therefore they tend to be readily reported by respondents. In contrast, work in the informal sector is generally sporadic and consequently may not be reported. While income or wages for a formal sector job are predetermined and fixed, wages in informal sector activities are often irregular, and highly likely to be meager as a result of piecemeal production.

Marital status is associated with life-cycle phenomena that have a significant bearing on a woman's capacity and need to seek employment. Hence a complete understanding of women's labor force participation must take marital status and its associated outcomes into consideration. This study develops four distinct models based on the marital status of women. The first is a pooled model that includes the 
eligible working and non-working women of all marital categories. It discusses the variables common to all women. Demographic variables include marital status, age, family size, number of preschool age children, and the presence or absence of a resource person. Marital status is included as a predictor variables. Socio-economic variables include the respondent's education, mother's education, and household income. Cultural variables include tradition, family objection, segregation and status.

The second is the single women's model. The demographic variables include the woman's age and family size. Socio-economic variables include the respondent's education, mother's education and household income. The cultural variables include the same variables used in the pooled sample model.

The third is the ever-married women's model, which includes both the currently-married and those who were previously-married, namely, widows, divorced and separated women. Here again marital status is included as a predictor variables. In addition to the variables discussed for the single women, it includes variables such as the number of preschool age children, and the presence or absence of a resource person.

The fourth is an extension of the third model but it focuses exclusively on currently-married women and includes 
variables related to the husband, namely education level and work income.

In the following section, an elaboration of the various variables discussed in the literature will be presented, along with some consideration of how certain variables will be outlined and hypothesized in this study.

THE POOLED SAMPLE MODEL

Demographic Variables

Marital status. It has been observed that single women tend to have higher participation rates than married women (Athanassiou, 1982; Azzam, 1978; Mujahid, 1985; Youssef, 1974). This is particularly true in countries where the overall female labor force participation rates are very low. The ratio of participation of married women to single women in Egypt, Syria, Lebanon, and Tunisia is $1: 4$ compared with 1:1 in Bulgaria, and 1:2 in France (Azzam, 1978).

In Jordan, the same pattern is reflected by the latest statistics on female labor force participation (Department of statistics, $1987 \mathrm{~b})$. The rate for single women is $67.6 \%$ compared with 27.18 for married women. For divorced and widowed women the rate at $5.3 \%$ is lower than both groups of single and married women. In his study in Jordan, Shakhatreh (1990) finds marital status to be the second most significant factor, after education. The results also show that single and previously married women have significantly 
higher labor participation rates than currently married women. Furthermore, single women have higher rates than previously married women.

Folbre (1986) argues that married women's labor force participation is determined by marriage dissolution through death, divorce or separation. Belhachmi (1985) argues that Islam fosters sexual asymmetry. Therefore, polygamy and divorce rights that favor the males, can put women at high-risk (Nassif, 1976; Yehia, 1977). Such situations when accompanied by poverty force women to seek work outside the home to support themselves and their children (Grown \& Sebstad, 1989). However, in the Arab Muslim society, certain restrictions on mobility are socially imposed on young divorced and widowed women (Abu Nasr, Khoury, \& Azzam, 1985). Since a man's honor depends to a great extent upon the virtue of the women in his household (e.g. daughters and sisters), the interactions of these women with non-kin males are severely restricted (Williams, 1990).

Another factor that determines the higher employment rates for single as opposed to married women is the employers' attitudes (Abu Nasr et al., 1985). Single women generally have fewer demands on their time in contrast to mothers and/or married women. Therefore, this study expects the single women to have higher labor force participation rates than married women. Among the ever-married women, previously-married women (widowed, divorced and separated) 
are expected to have higher labor force participation rates than currently-married women, because they lack the economic support that the husband provides.

Age. Age is a major determinant for both males and females. In general, the pattern of participation rates is roughly an inverted $U$, where the young (14-19 years) and the old (60 and above) have lower rates (Hamermesh \& Rees, 1984). However, for women, events such as marriage, childbearing, and widowhood may tend to interfere with their involvement in economic activity (Boserup, 1970; Standing, 1978). In Jordan, the labor force participation pattern showed a curvilinear relationship with lower rates for the young and old cohorts (Hammouda, 1985). The 1979 Census data indicated that the highest participation rate for females is in the 20-24 age group, while for males it is in the 30-34 year age group (Hammouda, 1985).

Younger women may have better opportunities to find work as a result of employers' attitudes. A survey of 240 organizations in the greater Beirut area undertaken by the Institute for Women's studies in the Arab world in 1980 showed that more than half of the employers preferred to employ young, single women. Employers expected nearly two thirds of their workers to be between 19 and 30 years old (Abu Nasr et al., 1985).

In this study, controlling for other variables in the pooled sample model, younger women are expected to have 
higher labor force participation rates than older women. However, the situation is governed by other events that punctuate the life cycle of a woman like marriage and childbearing. Therefore, among ever-married women, the younger ones are expected to have lower labor force participation rates than older ones because of childbearing and childrearing activities.

Family size. Family size is related to a woman's perceived need for income and thus could have a bearing on her decision to participate in economic activity (Anker \& Knowles, 1978; Hijab, 1988). Anker and Knowles (1978) state that the larger the family, the more the need for income, ceteris paribus. Peek (1978) found in Chile that family size had a positive effect on married women's labor force participation in both the traditional and modern sectors.

Engle (1980) cites evidence that women's desire to work is greatest in poorer households. The presence of many children is positively associated with paid work of women because of increased need. However, while family size may be a factor that positively influences women's economic activity because of need considerations, at the same time, it may be a deterring factor. Household chores which still are the woman's primary responsibility may take up the women's time and not allow for work outside the home. of particular influence is the number of children a woman has of preschool age, where demand on the mother's time is 
substantial and may override her propensity to undertake economic activity outside the home. In Jordan, Shakhatreh (1990) finds a significant negative effect of family size on married women's labor force partiaipation. As for single women, family size has a less significant effect. Similarly, this study expects family size to have a negative effect on women's decisions to participate in economic activity, particularly the married women, because of household chores and child-care responsibilities.

\section{Socio-Economic Variables}

Education. A strong positive relationship has been established between educational attainment and labor force participation in numerous studies (Athanassiou, 1980; Azzam, 1978; Elizaga, 1974; Hamermesh \& Rees, 1984; Mernissi, 1976; Mujahid, 1985; Nawar \& Nizamuddin, 1986; Standing, 1978; Sweet, 1973; Zurayk, 1979).

Researchers have advanced several explanations for this. According to Bowen and Finegan (1969), education increases both the opportunities for paid employment and women's awareness of alternatives. It implies better information about labor market opportunities (Azzam, 1978). It raises the opportunity cost of being out of the labor force by increasing the person's expected market wages.

Education is seen by many economists as a proxy measure for a woman's opportunity income or for improving her possibility of obtaining employment (Anker \& Hein, 1986). 
It is a factor that increases females' aspirations and expectations, and consequently encourages them to take advantage of the chances open to them (Azzam, 1978; Standing, 1978; Zurayk, 1979).

The empirical evidence for a positive relationship between education and women's participation is cited by Elizaga (1974) in Chile and Argentina, by Anker and Knowles (1978) in Kenya, by standing (1976) in Jamaica, and by Athanassiou (1982) in Greece. However, Standing (1978) argues that the relationship between education and women's work in the developing countries is not clear and is rather complex. Although the relationship is seen as positive, a negative relationship is possible especially among highly educated women who may be reluctant to accept low-status jobs that do not meet their expectations. Standing (1978) also found that the relationship is affected by the level and structure of labor demand. The association may be positive at both high and low levels of demand but negative at the intermediate level. The association between years of education and female labor force participation may be nonlinear. Some studies in India and Pakistan also show a nonlinear relationship between education and women's participation (Farooq, 1975).

According to the 1976 Household Survey in Jordan, a positive correlation with female labor force participation was found only beyond secondary level (Department of 
Statistics, 1976). The participation level of women with less than secondary education was reported to be even lower than for women with no schooling (Mujahid, 1985). Shakhatreh's (1990) study in Jordan reveals that education is the most significant factor that affects women's decisions to work. The effect of education becomes more positive for secondary education and beyond. Illiterate women show the lowest participation rate of all.

Azzam (1978) suggests that education improves the employment opportunities for women and helps them to be selected for specific jobs. It encourages more female mobility in search for employment, and increases women's aspirations for higher incomes, better standards of living and more self awareness and growth. It also weakens the restrictive barriers of cultural traditions and increases the propensity of women to join the labor force (Azzam, 1978).

Education is considered to be a factor that changes both men's and women's attitudes toward women's work and the type of economic activities relegated to women. This could lead to facilitating women's entry and competition in the labor market (Gerner-Adams, 1979; Zurayk, 1979). Education may also increase women's age at marriage and consequently act as a conducive factor in increasing women's opportunities (Curtin, 1982). 
This study expects education to positively affect labor force participation rates of women in the pooled sample. The same is expected for the single women. However, for the ever-married women, other factors, such as the presence of preschool children, and need reflected by the family size and the household income, are expected to have more bearing on women's labor force participation. Moreover, women's work in the informal sector usually does not require high levels of education. Hence, education may not have a strong effect on women's work situations.

Mother's Education. Mother's education is assumed to have an effect on the female labor force participant, since it affects their attitudes towards sex roles in general. In his study on female labor force participation in Jordan, Shakhatreh (1990) examines the effect of both the mother's and father's education on the labor force participation of single women. His results show a more significant effect of the father's than the mother's education. However, methodologically, that was mainly due to the small number of educated mothers in the sample. The effect of the mother's education was nevertheless found to be larger in magnitude than that of the father. Chekaibe's (1990) study in Beirut, Lebanon, shows no systematic effect of the father's education on women's employment.

In this study, the mother's education is not expected to show any significant effect on the labor force 
participation of women. This is due to the fact that education distribution of the baseline data of the study population (Save the Children, 1987) showed high illiteracy rates concentrated in the women aged 40 years and over. These represent the mothers of the young women in this study sample. Among these women, $97.5 \%$ either had only elementary education or were illiterate.

Household Income. Many scholars discuss household income as a factor that has a bearing on female participation in the work force. However, empirical studies have generated conflicting conclusions. Some scholars note that with the increase in household income (total family income excluding the woman's income) women are more likely to leave the labor force than other family members. Hence, the relationship between family income and women's economic activity is generally found to be negative (Athanassiou, 1982; Bowen \& Finegan, 1969; Elizaga, 1974; Steel \& Campbell, 1982; Sweet, 1973). Shakhatreh (1990) finds that available household income (excluding the respondent's contribution) had a significant negative effect on evermarried women's labor force participation in Jordan. His results match those of Peek (1978) in Chile, and Anker and Knowles (1978) in rural Kenya.

on the other hand, Anker and Knowles (1978) find this relationship to be positive in urban areas in Kenya. They indicate that the need for income as seen by the women 
depends on two factors. These are family income excluding the woman's contribution, and the felt need for material goods which is considered as a part of one's taste function. However, the felt need factor was not included in their analysis because of lack of data. The positive relationship between household income and women's economic activity was also found by Sheehan (1978) in a study in Khartoum, Sudan, and by Rasevic (1978) in Yugoslavia.

Tovo (1984) uses the term "available income" to measure the income available to the household without considering the woman's earnings. In this study, available household income is calculated as the monthly total household income from all sources excluding the respondent's work income. This cancels the effect of the women's contribution to household income for those who work, and therefore unifies the effect of household income on women's labor force participation for both the working and the non-working women.

The expectation in this study is that household income will have a negative effect on women's labor force participation, but less so for the single women. First, young single women, within the cultural context, may see themselves as dependents on their parents (for financial support), and therefore may not feel compelled to contribute to family income. Second, because of their presumably higher education levels, their motive to work may reflect 
more a desire to achieve personal fulfillment and financial independence through satisfaction of personal needs rather than to contribute to family income.

Wages. Bowen and Finegan (1969) argue that education raises the opportunity cost of being out of the labor force by increasing the person's expected market wages. A higher potential wage implies a higher opportunity cost for staying at home. Thus, increasing the market wage can be expected to positively affect female participation (Steel \& Campbell, 1982). This was also substantiated by Schultz (1989) in Thailand, and by Levine and Wong (1989) in Mexico.

Smith (1980) and Levine and wong (1989) argue that while conceptually the woman's wage is an important consideration, it raises a methodological problem since wages are only observed for those who work. For those who do not, the potential wage offer is unknown. Because wages are a function of age and education, they find it methodologically more appropriate to enter those two variables directly in the model of female labor force participation.

Anker and Knowles (1978) in Kenya, and Shakhatreh (1990) in Jordan, find that both the wage offer and the regional unemployment rate had no significant effect on women's decision to work. Shakhatreh relates that to the importance of other than economic factors that influence women's labor force participation. In culturally-specific 
contexts, certain demographic variables (such as fertility and family size) and cultural variables (like women's traditional sex roles and societal attitudes and values) may have an equally important, if not more bearing, than the economic variables on a woman's decision concerning labor force participation. Moreover, for the women who are not working, wage offer cannot explain the full array of reasons why a woman does not work. Wage offer is particularly irrelevant for those who do not work and do not wish to work. Since wages are a function of education and age, the wage variable is not included in the models of this study, while the other two are.

\section{Cultural Variables}

Cultural factors have their influence on shaping the status and roles of women, and consequently have a bearing on women's state and level of economic participation. Cultural restrictions on female labor force participation have been stressed in much of the related literature (Uthoff \& Pernia, 1986). Anker and knowles (1978) and steel and Campbell (1982) indicate that cultural factors are considered an important component in the costs and benefits associated with work. For example, in areas where a stigma is put by society on women working outside the home or where certain kinds of jobs are considered inappropriate for women, the social cost of women's work can be very high. This can hinder their participation in the labor force or 
constrain their choice of occupation. Thus, cultural segregation may result in higher unemployment and lower wages for women compared to men. It may also result in the exclusion of women from certain occupations as well as reducing their labor force participation rates (steel \& Campbell, 1982; Youssef, 1974).

To capture the effect of cultural factors on married women's work in Kenya, Anker and Knowles (1978) used binary variables to depict three types of conjugal relationships: Muslim wives, wives of polygamous men, and women whose husbands are living away from home.

steel and Campbell (1982) present four cultural determinants of female labor supply; namely religion, social norms, attitudes, and discrimination. They argue that Islamic prohibitions against female contact with men outside the family impose a heavy social cost on women who nevertheless decide to seek market employment, and sharply restrict their choice of occupations. Social norms regarding women's proper place in the home have negative effects on women's decision to join the work force. Women's attitudes toward the acceptability of market employment have a significant effect on female labor supply. As for discrimination, they stress the importance of labor market segregation against women, which may result in a higher unemployment rate, and lower wages compared to men. 
Societal norms may affect both the supply and demand of female labor. The culturally-specific restrictions on women's choice of occupations mentioned above make it more difficult for women to obtain suitable employment. On the other side of the equation, social norms which greatly value women's role in the home (Chekaibe, 1990; Zurayk, 1979) lessen the likelihood that women will seek work outside of it, even if such work were readily available. cultural factors are invariably cited by writers who discuss the reasons behind the low participation of Arab women in wage-labor activity. For example, in terms of social norms lowering the supply or offer of female labor to the market, Gerner-Adams (1979) points to the traditional family and societal attitudes as well as to the low female literacy rate in Arab countries. More specifically, Zurayk (1979) claims that Arab societal values still strongly maintain the traditional importance of the role of the woman as wife and mother throughout her adult life. Smock and Youssef (1977) contend that the low female labor force participation characteristic of Islamic societies reflects the sexual division of labor, in which the woman's place is considered to be the home. Chekaibe (1990) argues that finding a job outside the home is not part of the sex-role socialization of Arab females. To become a wife and a mother is what generally occupies the soul and mind of a typical Arab woman (Chekaibe, 1990). 
Rockwell (1985), in a study of Palestinian women workers in Gaza, finds that families tend to hide or deny the fact that female members work, since women's work is socially associated with household poverty. Embarrassment with women working outside the home stems from the patriarchal family structure, where men have traditionally been responsible for all their female dependents, and where male prestige rests on the ability to protect family honor through the isolation of women (al-Khayyat, 1990; Hoodfar, 1990; Kandiyoti, 1988; Moghadam, 1992). Nevertheless, El Solh (1985) argues that when ideal and reality clash, economic self-interest would tend to override the adherence to customs and tradition.

Hijab (1988) highlights the tendency in the literature to turn to socio-cultural factors, when other reasons may be as, if not more, important to explain women's low participation in the work force. Faroog (1975) criticizes the assumption that the low levels of female labor force participation in many Muslim societies are related to religious attitudes. His criticism is based on the fact that such an assumption fails to explain the high levels of female labor force participation in certain Muslim countries such as Turkey and Indonesia, or the low levels in nonMuslim countries such as Honduras and Costa Rica. Moghadam (1992) refers to a U.N. survey cited in Boserup (1990) which relates the consistently low level of women's work in 
countries with a predominantly Muslim population to cultural restrictions that discourage women from doing certain types of work. Along the same argument, she points out to earlier attempts that have been made to explain the South Korean and East Asian economic phenomena in cultural terms, and contends that such explanations have been dismissed as theoretically deficient. Culture cannot be isolated as a factor that explains the full range of possible explanations for Muslim women's low labor force participation rates. Papps (1992) argues that it is not clear whether the low participation rate of Arab women is a result of supply factors, demand factors, or some set of factors which are common to Muslim countries but unrelated to religious values. Youssef (1974) finds that female labor force participation is higher in Latin American than in Middle Eastern countries. Nevertheless, she contends that the Catholic culture of Latin America provides a set of constraints for working women which are similar to those of Islam. However the difference, she claims, lies in the difference in family structure and social relations in the two regions. Papps (1992) concludes that although it is obvious that there are some factors in the Muslim Middle East which are responsible for low recorded levels of female labor force participation, it is difficult to disentangle the effects of Islam from other cultural factors. She cites some studies that look into the effect of the Islamic 
culture on women's labor force participation and emphasizes that no evidence has been established for a direct impact of Islamic attitudes on female labor supply decisions. Statistical works which examine the effects of other factors are often confounded by difficulties because of the high degree of correlation between different pertinent variables such as the level of economic development and education (Papps, 1992; Youssef, 1974).

The high fertility level at 6.3 (Department of Statistics, 1984) in Jordan may be a true reflection of the traditional norms and societal values that favor a large family size (Cornelius, 1988; UNFPA, 1979). Tutunji (1978) claims that women in Jordan do not like to work outside the home; most aspire to get married and start a family. Takriti and Kawar (1990) argue that given the fact the women's household and child care responsibilities are seen as a full-time occupation, mothers' economic activity outside the home would only give them an added burden without necessarily increasing their status.

In his study in Jordan, Shakhatreh (1990) uses religious affiliation as a proxy for cultural and attitudinal factors, since his data set does not have any cultural variables. His findings verify the effect of religion whereby Christian women had higher labor force participation rates than Muslim women. He stresses the importance of cultural factors influencing female labor 
force participation. He hypothesizes that single women are less likely to be affected by cultural factors than married women, because they are mostly younger, and presumably more educated; hence they may have more liberal views towards women's work and life affairs. However, contrary to his hypothesis, single women are found to be more affected by cultural factors than married women. Chekaibe (1990) looks at childhood residence to depict urban versus rural effects on cultural and social norms. Her hypothesis is based on the belief that cultural forces are weakened within the city (Beirut). However, her data statistically indicates that liberal attitudes are not necessarily a function of urbanrural living.

Based on the above discussion, religion as a variable used by Shakhatreh (1990) does not have a direct bearing on explaining cultural effects on female labor force participation, nor does childhood residence as used by Chekaibe (1990). Therefore, this study defines and operationalizes certain variables that are presumed to reflect firsthand societal norms and cultural attitudes of the respondents in the communities under investigation. The cultural variables defined for this study are tradition, family objection, segregation, and status.

Tradition is preconceived as a constraint that deters a woman from undertaking economic activity. It reflects her perception of her role as homemaker and childrearer. 
Family objection reflects more the attitude of parents and family members regarding the women's involvement in economic activity. It is preconceived as a constraint to women's economic activity.

Segregation is also preconceived as a constraint. It indicates that a woman is prohibited from working in gendermixed environments, or that she herself would not work in a mixed place. Women who have the segregation constraint, are expected to be less economically active, or are expected to be working in the home.

Status is a variable that is constructed to reflect a women's status and decision making power in the household as a result of her being economically active (and potentially a contributor to family income). It is hypothesized to be a positive factor that increases women's labor force participation.

This study expects a stronger influence of cultural variables on single than ever-married women's involvement in economic activity. Although young and educated single women may have more liberal views towards women's work and women's role in general, their life affairs, such as mobility and social conduct may be constrained by the conservative views of their parents and other adult kin. It is also expected that cultural variables will have less influence on the previously-married than the currently-married women. This is mainly because of the absence of a direct male kin--the 
husband--to dictate mobility and place and type of work for the woman. If need is a compelling factor for the widowed, divorced or the separated woman to work, then the presence of other male kin, like the father or brother, implies more a moral-protective role.

\section{SINGLE WOMEN'S CONCEPTUAL MODEL}

Single women are those who have never married. In the Jordanian society, these women typically live with their parents, and their financial requirements are primarily the responsibility of the father. Moreover, social and cultural norm dictates that they are the moral obligation of primarily the father and brothers and the immediate male kin. In Jordan, single women are never expected to have children before marriage.

Since single women in the younger age groups (15-19 and 20-24) are more likely to be students than in the labor force, only those single women who are not students, and the students who are economically active, are included in the eligible pool of women who comprise the sample of this study.

Except for the child variable (i.e. the number of preschool children) and the presence of a resource person, all the variables that were specified for the pooled sample of women are included in the single women's model, using the same measures and definitions. 
EVER-MARRIED WOMEN'S CONCEPTUAL MODEL

Besides the variables that were discussed for the pooled sample of women, and the single women, two variables are added to the ever-married group, namely the child and the resource person variables. The first reflects a woman's fertility and the second refers to the child-care substitute.

Fertility. The relationship between women's reproductive and productive roles has been extensively researched. Some studies find that the participation rate of married women without children is much higher than those with children (Athanassiou, 1982; Chekaibe, 1990; Shakhatreh, 1990; Standing, 1978; Youssef, 1982). Several interpretations, based on sociological and economic perspectives, have been used to explain an inverse relationship between women's work and fertility (Simmons, 1986; Stycos \& Weller, 1967; United Nations, 1985; Youssef, 1982). However, most studies in developing countries show a weak or non-existent relationship (Anker \& Knowles, 1978; Concepcion, 1974; Nawar \& Nizamuddin, 1986; Stokes \& Hsieh, 1983).

Anker and Knowles (1978) suggest that the difference in the impact of child care on women's employment between developed and developing countries may be related to the low opportunity cost of child care in the latter. The low 
opportunity cost of child care in developing countries is due to the availability of free child care through household members (Deeb, 1988) or through hiring low-cost child care (Levine \& Wong, 1989).

In this study only the number of preschool age children (infants and children up to age 6) is hypothesized to have an effect on ever-married women's labor force participation. The expectation is that the greater the number of preschool age children a woman has, the less likely she is to be economically active.

Child care. In traditional societies and communities, the sexual division of labor tends to be rigid. Child care becomes exclusively a woman's responsibility and consequently reduces women's labor force participation (Boserup, 1970; Cain et al., 1979; Dixon, 1982). In a study from Bangladesh, Archarya and Bennett (1982) emphasize that nuclear families are becoming the norm, and that traditional family support networks for women are breaking down.

Durand (1975) reports that it is the presence of preschool age children, rather than the number of children, that affects women's employment outside the home. This is substantiated by Bowen and Finegan (1969). The presence of children under six years takes precedence over all other aspects of the age distribution of children in determining the participation of the mother in the labor force. 
In general, the availability of child care alternatives may be expected to help determine the opportunity for mothers to work in incompatible jobs. Doan and Popkin (1989) find that, in their sample from the Philippines, the availability of a child care substitute positively affects the participation of women in the work force and increases the percentage of mothers in incompatible jobs. Engle (1980) emphasizes that work that is compatible with child care tends to be associated with low pay and low status. Peek (1978), in a study using data from Chile, finds no effect of child care burden on the mother's chance of being employed in the traditional sector of the economy, since traditional sector activities are congruous with child care. However, in the modern sector, he detects a negative impact of the child care burden on the mother's work.

In a study from the United States on the "Class of 72 " data set, Tovo (1984) finds that although the participation of women in the labor force appears to be strongly constrained by the presence of young children, this represents a temporary situation or a life cycle phenomenon. As children get older, they present less of a constraint on the mother's time and may even serve as a substitute in household tasks, including caring for younger siblings.

In studying the effect of fertility on women's work in Jordan, Shakhatreh (1990) looks into the age and the number of live born and surviving children. His findings indicate 
that a childless mother is more likely to be in the labor force than the woman who has surviving children. Also that the mother of preschool age children is less likely to be in the labor force than a woman who has infants or school-age children. Chekaibe's (1990) study in Lebanon verifies a negative relationship between fertility (number of children) and married women's economic activity. The rates of female economic participation decline when women have three children or more. Working women with preschool children generally worked if a close kin was available to help in caring for the youngsters.

This study defines the resource variable as the person or persons who help a married woman with household chores and child care activities. The expectation is that the presence of a resource person in the household increases the possibility of the ever-married women being in the labor force.

\section{CURRENTLY-MARRIED WOMEN 'S MODEL}

The two variables that were added to this model because they only apply in the case of currently-married women, are the husband's educational level and husband's income. Although education level is considered a variable that usually determines income, it is entered in the model to test its relevance and significance on married women's economic participation. It is hypothesized to have a 
positive effect on women's labor force participation, due to two reasons (Barhoum, 1983). First, an educated man is more likely to marry an educated woman, whose chances for employment are presumably higher. Second, an educated man may have a more liberal attitude about his wife being in the labor force. The husband's income variable replaces the household income in the currently-married women's model (to avoid collinearity). Like household income, it is expected to have a negative effect on the married woman's labor force participation.

\section{MAIN HYPOTHESES}

The preceding discussion can be summarized with the following hypotheses:

1. Single women are more likely to work than married women.

2. Among ever-married women, previously-married (widowed, divorced, and separated) women are more likely to work than currently-married women.

3. Younger women are more likely to work than older women.

4. Among ever-married women, younger women are less likely to work than older women.

5. Education positively affects women's labor force participation, particularly single women. 
6. A greater number of preschool age children negatively affects ever-married women's labor force participation.

7. The presence of resource person positively affects ever-married women's labor force participation.

8. Family size has a negative effect on ever-married women's labor force participation.

9. Household income has a negative effect on evermarried women's labor force participation.

10. Husband's income has a negative effect on currently-married women's labor force participation.

11. Culture affects the single women more than the ever-married women.

12. Among ever-married women, culture is likely to have more effect on previously-married than currentlymarried women. 
DATA AND METHODOLOGY OF THE STUDY

This chapter describes the data and statistical techniques that are used in this study. The analysis is carried out in two parts. The first uses the secondary data set which was the result of the comprehensive baseline survey conducted by save the Children, in 1987. This population constitutes the frame from which a sample was drawn to comprise the second part, which is the main thrust of this study.

The major findings of the analysis of the 1987 data set were of particular significance in shaping the conceptual framework of this study, and in directing the methodological specification for the models used in this research. Therefore these findings are provided in the next section.

\section{SECONDARY DATA SET}

In 1987 the population of the study areas of Natheef, Mahatta, and Musdar was 12,192. It consisted of 1,731 households. The average household size was 7.1 persons. The population was comprised of 5,914 females (48.5\%) and 6,278 males (51.5\%), which was similar to the sex 
distribution of the Jordanian population for the same year (Department of Statistics, 1987b).

The age distribution showed that $45.9 \%$ of the total population is in the age group 0-14 years, indicating a youth population and a high dependency rate.

Thirty-three percent of the females and $11 \%$ of the males were illiterate. Women had an overall lower education level than men, and the higher the level of education considered, the wider the gap.

The analysis of the baseline data showed that the mean household income is Jordanian Dinars (J.D.) 118.6, and the median J.D. 100. (Since 1987, the exchange rate for the Jordanian Dinar has been U.S. \$1.45.) A total of 110 households $(6.4 \%)$ had no reported income. The national poverty line was defined in 1987 at J.D. 89 per month, and at J.D. 96.6 for the Amman Governorate for a family of 7.2 persons (Ministry of Social Development, 1987). While 18.7\% of the Jordanian population fell at or below the national poverty line, $44.5 \%$ of the study population was living under similar conditions, which confirms that these are indeed communities with a high concentration of poor households.

The data collected for adult female members (age 15 and over) included employment status, type of employment and income. Statistical analysis of the data set showed that the majority $(71.5 \%)$ of the women defined themselves as housewives. Sixteen percent were students and $3.5 \%$ were 
ineligible (either too young or too old to work). Nine percent of the women were involved in economic activity. Among those who worked, $69 \%$ were involved in what is conventionally defined as informal sector activities. Though the average earnings were low in absolute terms, the contribution as a percentage of family income was substantial. of those women who earned income, $35 \%$ contributed $50 \%$ and more of the household income, and $15 \%$ were the sole income earners. Among the working female heads of households, the highest incidence appeared for the widowed women followed by those who were divorced, and they mostly took menial jobs.

Nine percent of women were designated to be working although a substantial number reported themselves as housewives. Anker (1984) argues that the preconceived notion of women being mostly housewives is thought to affect the way survey questionnaires are designed and how survey questions are actually asked by interviewers, in addition to how respondents reply to these questions. Most women would tend to define themselves as housewives, due to their perception of their traditional roles. Whether a woman perceives her economic activity as "work" and the returns from her work as "income," determines whether she would report herself as a working woman. In most cases, women fail to recognize their work and contribution as such, or at best consider it to be secondary and marginal. This is 
mainly because in many cases the economic activities they undertake are irregular or done as piecework and because the financial returns from such activities are meager. Hence, women see their economic roles as secondary and only as an extension to their traditional roles.

This situation has profound implications for the definition of work and female economic activity in this study. Thorough probing was warranted to determine whether a respondent would be classified as working or non-working, and to determine actual economic activity and the amount of income accruing as a result. A "housewife" category was not allowed. Women's economic status was categorized to reflect the type of economic activity as either active, inactive or ineligible for economic activity.

\section{STUDY SAMPLE}

This study targets adult females over 15 years of age. The sample selection depended on households rather than individual females as a unit of analysis for the following reasons:

- The 1987 data set covered only those adult females who were over 15 years of age. Hence, selecting the new sample from the 1987 adult female pool would exclude those females, who by 1992, would have been eligible for inclusion, based on their current age. 
- The three communities of Natheef, Mahatta and Musdar were geographically defined and mapped by Save the Children. These communities are very dense with no room for physical expansion, therefore, the actual house and household numbers did not change over the period 1987 to $1992 .^{3}$

- Since poverty is a main concern in this study, household income was considered the basis of stratification for sampling.

- A $12 \%$ sample $e^{4}$ was drawn, using the sPSS random selection by household number. A proportional stratified sample reflected three different household-income levels; the lowest are households with incomes ranging between zero and J.D. 96.6, which was the poverty line for 1987; medium income between J.D. 96.7 to J.D. 350; and high income, over J.D. 350 per month. The sample yielded 209 households with a total of 435 adult females. The

${ }^{3}$ Change in the households was expected to have occurred between 1987 and 1992 as a result of mobility. However, the actual implementation of the survey verified the existence of the same families in the same dwellings, except for one case. Only structural demographic change has occurred.

${ }^{4}$ The goal was to achieve results with $95 \%$ confidence level at the $5 \%$ level of significance. This required a sample size of at least 384 females. 
mean monthly household income was J.D. $216.450^{5}$ (equivalent to U.S. $\$ 313.85)$. The average household size was 7.02 persons. The total sample population consisted of 435 female and 486 male adults.

\section{QUESTIONNAIRE DESIGN AND DATA COLLECTION}

The field survey was carried out in June of 1992. It took three weeks to cover the 209 randomly selected households. This process was preceded in early May, by two weeks of unstructured interviews. This pretest phase helped to clarify certain concepts and accordingly modify the questionnaire, and to train the field surveyors. Three professional surveyors were recruited to carry out data collection. They already had experience in carrying out socio-economic surveys. However, they needed to develop a better understanding of what economic activity entailed. Consequently, they were trained to probe for identifying economic activity. For example, during the pre-test phase, it was brought to their attention how a woman would designate herself as housewife (which generally implies that she is economically inactive), and at the same time would be working on a piece of embroidery. They were told to ask

The 1987 average household income was $118.60 \mathrm{JD}$. The corresponding 1992 average nominal income was $216.45 \mathrm{~J} . \mathrm{D}$. With a cost of living index increase of nearly $75 \%$, the two figures are nearly identical in real (inflation free) terms. (Source: Central Bank of Jordan, December, 1992.) 
about this activity in order to ascertain if it was being done for income generation.

Demographic and socio-economic data were gathered for all adult members of the households in the sample. Furthermore, comprehensive data were gathered for the adult females, which included details on economic activity, perceptions regarding their domestic versus economic roles and details pertaining to cultural attitudes.

A copy of the translated version of the questionnaire is found in Appendix B. The first part covers the demographic data including variables such as age, sex, marital status and family size. The second part covers the socio-economic variables including respondent's education, employment status, occupation, place of work, and earned income. Household income was later calculated as the sum of the earnings of all household members. 6

Female employment status was classified into seven categories:

1. work full-time

2. work part-time

3. do not work; wish to work

4. do not work; do not wish to work

5. student

6. ill, incapacitated; cannot work

7. too old to work

${ }^{6}$ The questionnaire included other variables that were not included because they were not found to be of particular value for the study. 
Those who are currently working and those who have undertaken any economic activity during the last three months comprise the economically active group. Categories 1 and 2 of the classification are those who are economically active (working either full-time or part-time). Those women who are not working, but wish to work (category 3) represented a potential work-force that was seeking employment. Category 4 includes the women who are not working for reasons that the study is attempting to determine. Categories 5, 6, and 7 represent the women who are ineligible for work force participation, because they are students, ill or too old to work. Students who reported economic activity were included in the pool of working women. When a woman specified herself as housewife, the surveyor continued probing, until the respondent was classified as belonging to one of the employment-status categories iterated above.

The third part of the questionnaire involved three detailed sheets that captured the employment status (whether a women worked or did not work). This part was also designed to capture the cultural and social attitudes of the women as they relate to their economic activity.

Each sheet included a list of the reasons why a woman worked or did not work. The reasons were not read to the respondent; instead her answers were marked down as 
provided. The respondent was asked to identify the most and second most important reasons for working or not working. Sheet "A" was filled for the working woman. It included a list of reasons why she worked. These answers reflected the motives and incentives that caused a woman to undertake economic activity. Sheet "B" was filled for the non-working woman who wished to work, and sheet "C" was filled for the non-working woman who did not wish to work. Sheets "B" and "C" for the non-working women iterated the reasons as to what constituted the obstacles and disincentives to work. These reasons included demographic, economic and cultural factors. The reasons pertaining to culture were combined and operationalized as cultural variables for inclusion in the models.

\section{METHODOLOGY}

Female labor force participation is the dependent variable in this study. Those women who are students, ill or incapacitated, or too old to work were excluded from the analysis since they are ineligible for labor force participation. Women who are working, either full-time or part-time, women who are not working and wish to work, and women who are not working and do not wish to work constitute the eligible pool of women who are the subject of this analysis. 
The study reports the results of frequency tabulations, bivariate and multivariate analyses. Certain bivariate tabulations present the descriptive part of the study sample. Cross-tabulations also examine certain bivariate relations. The bivariate analysis assesses the strength of the relation between two variables at a time without controlling for other variables.

The multivariate analysis provides additional insight into the relative importance and statistical significance of each independent variable by simultaneously controlling for other relevant variables. This analysis ascertains the proportion of the variation in the dependent variable (likelihood of labor force participation) that is accounted for by the set of independent variables identified for the study .

The multivariate analysis at the micro level employs the logistic (logit) regression technique. The predictive models use all predictors which show significant bivariate associations. This involves the specification of an appropriate model in which the independent variables are a set of variables whose distributions affect the dependent variable.

The regression log linear "logit model" is used where work/non-work is the binary dependent variable, and demographic, economic, and cultural variables are the explanatory ones. Three runs were carried out, one for the 
pooled sample (all women with the relevant common variables), another for the single women, and the third for the ever-married women. A fourth run addressed the currently-married women using variables related to the husband, like the husband's education and husband's income.

\section{MODEL SPECIFICATION}

A regression model is used to examine the relationship between women's labor force participation and a set of predictor variables. In estimating the parameters of a linear regression model, ordinary least squares (OLS) is the method used most often.

$$
\mathrm{Y}_{1}=\beta_{0}+\beta_{1} \mathrm{X}_{1 \mathrm{i}}+\beta_{2} \mathrm{X}_{2 \mathrm{i}}+\ldots+\beta_{\mathrm{k}}+\epsilon_{\mathrm{i}}
$$

Since the dependent variable is dichotomous, such that a woman can either be working (denoted as 1) or not (coded as 0$)$, the use of the oLS estimation of the regression has certain problems (Gujarati, 1992):

1. The error term $\left(\epsilon_{i}\right)$ in the model does not follow a normal distribution; rather, it follows the binomial (probability) distribution.

2. The error term $\epsilon_{i}$ is heteroskedastic, i.e. it does not have a constant variance.

3. The estimated $P_{i}$ (the probability that the event will occur, in this case labor force participation by wcman $_{i}$ ) may not fall within the range of 0 and 1 , a meaningless result. 
4. The model assumes that the rate of change of probability per unit change in the value of the explanatory variable is constant, given by the value of the slope.

Thus, logistic transformation was used, since it provided the linearity of the logistic function. Logit, known as the odds ratio, indicates the odds in favor of undertaking some action. The mathematical form of the model is:

$\operatorname{Logit}(P)=\operatorname{Ln} P\left(Y_{i}=1\right) /\left(1-P\left\{Y_{i}=1\right\}=\beta_{0}+\beta_{1} X_{1}+\beta_{2} X_{2}+\ldots\right.$ $+B_{n} X_{n}+\epsilon_{i}$

Where:

$P\left(Y_{i}=1\right)$ is the probability of working for the th woman for given characteristics,

$I_{n} P\left(Y_{i}=1\right) /\left(1-P\left(Y_{i}=1\right\}\right)$ is the natural log of the probability of working for the ith woman for given characteristics to that of not working (odds ratio).

$\beta_{0}$ is the constant

$\beta_{i}$ is the set of regression parameters, $i=1 \ldots n$

$\mathrm{x}_{\mathrm{i}}$ is the set of explanatory variables, $i_{1}=1 \ldots \mathrm{n}$

$\epsilon_{i}$ is the error term.

Several statistical packages run logistic regression such as SPSS, SAS, BMDP, and OSIRIS. This study used SHAZAM.

It is the contention of this study that women's decisions regarding labor force participation is carried out at two stages. The first stage involves a woman's decision 
as to whether to undertake economic activity or not. This decision is believed to be influenced by demographic and socio-economic determinants.

The second level decision of where to work (inside or outside the home) seems to be governed by cultural considerations. The nested logit method allows for the use of a binary technique to model such an inherently multichoice decision. Therefore, the first step of the nested logit model for each run includes the demographic and socioeconomic variables. The second step, in addition, includes the cultural variables to depict their influence on a woman's decision. The first alternative of whether to work or not is considered the "base" alternative. The second possible choice is compared to this base alternative with a logit equation. The dependent variable of these equations is the log of the odds of the ith alternative being chosen compared to the base alternative. The four equations show the dependent variable as the logit of the probability of women undertaking economic activity regressed on the predictor variables. Predictor variables consist of demographic, socio-economic and cultural variables.

Figure 1 illustrates the four models of the first stage of the nested logit; the pooled sample and the three marital categories, and Figure 2 illustrates the second stage of the nested logit. 


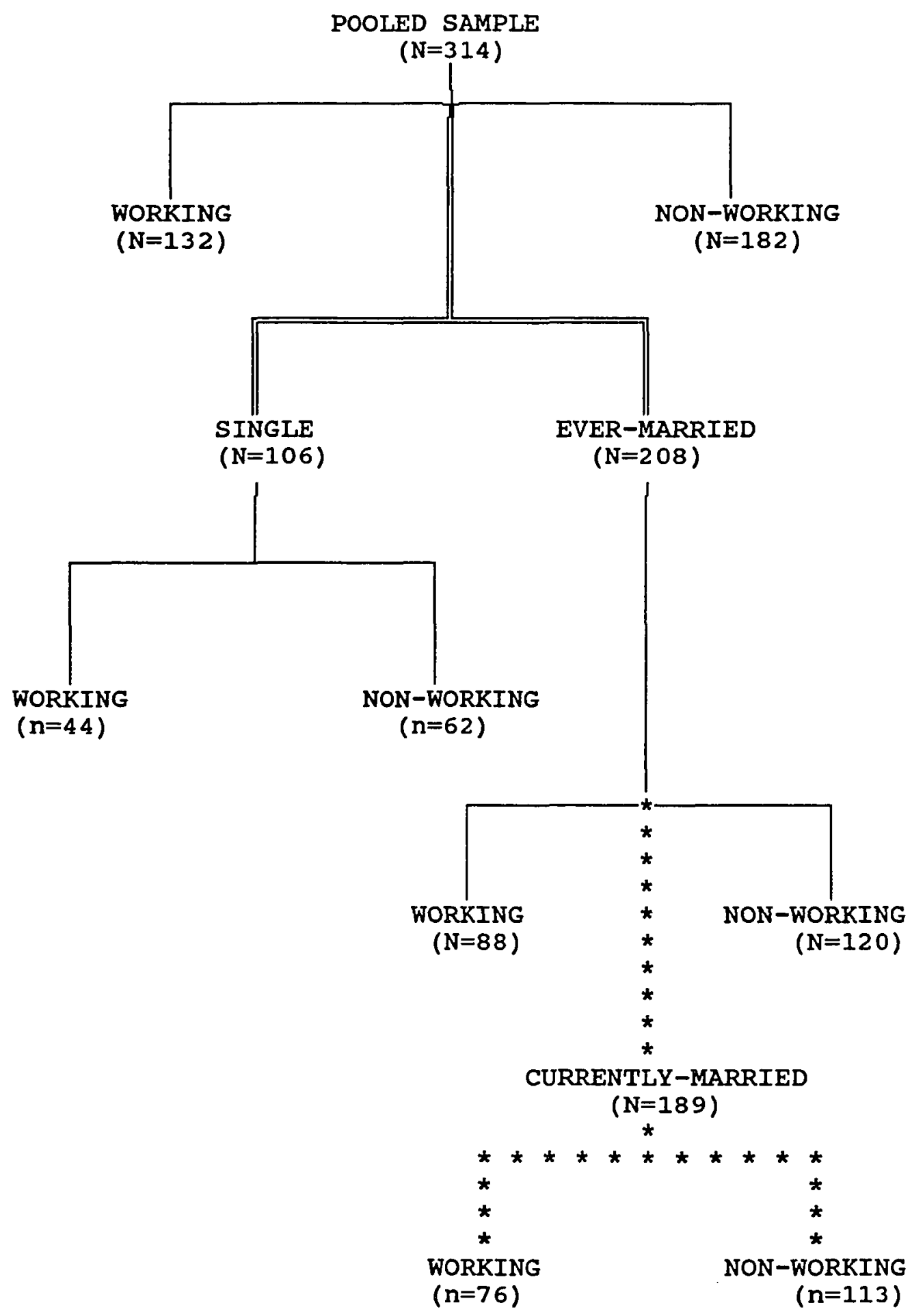

Figure 1. The pooled sample model (demographic and socio-economic variables). 
POOLED SAMPLE

WORKING WOMEN

$(\mathrm{N}=132)$

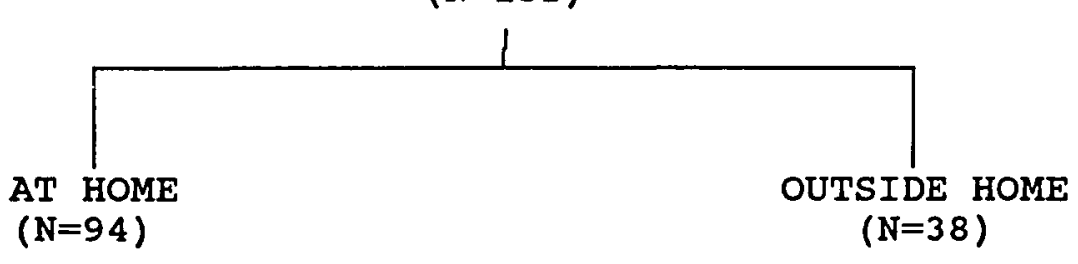

Figure 2. The pooled sample model (demographic, socio-economic, and cultural variables).

Pooled Sample Model

$\log \left(P_{i} /\left(1-P_{i}\right)\right)=\beta_{0}+\beta_{1}$ MARITAL $+\beta_{2}$ AGE $+\beta_{3}$ EDUCATN +

$\beta_{4}$ MOTHEDUC $+\beta_{5}$ FAMSIZE $+\beta_{6}$ AVHHINC $+\beta_{7}$ CHILD $+\beta_{8}$ RESOURCE $+\epsilon_{i}$

( $(A / 1)$

Single Women Model

$\log \left(P_{i} /\left(1-P_{i}\right)\right)=\beta_{0}+\beta_{1}$ AGE $+\beta_{2}$ EDUCATN $+\beta_{3}$ MOTHEDUC +

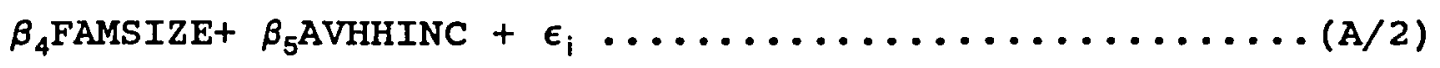

Ever-Married Women Model

$\log \left(P_{\mathfrak{V}} /\left(1-P_{i}\right)\right)=\beta_{0}+\beta_{1}$ MARITAL $+\beta_{2}$ AGE $+\beta_{3}$ EDUCATN +

$\beta_{4}$ MOTHEDUC $+\beta_{5}$ FAMSIZE $+\beta_{6}$ AVHHINC $+\beta_{7}$ CHILD $+\beta_{8}$ RESOURCE $+\epsilon_{i}$ $(\mathrm{A} / 3)$

Currently-Married Women Model

$\log \left(P_{i} /\left(1-P_{i}\right)\right)=\beta_{0}+\beta_{1}$ AGE $+\beta_{2}$ EDUCATN $+\beta_{3}$ MOTHEDUC + $\beta_{4}$ FAMSIZE $+\beta_{5}$ CHILD $+\beta_{6}$ RESOURCE $+\beta_{7}$ HUSBINC $+\beta_{8}$ HUSBEDUC $+\epsilon_{i}$ 
Pooled Sample Model

(Including Cultural variables)

$\log \left(P_{i} /\left(1-P_{i}\right)\right)=\beta_{0}+\beta_{1}$ MARITAL $+\beta_{2}$ AGE $+\beta_{3}$ EDUCATN +

$\beta_{4}$ MOTHEDUC $+\beta_{5}$ FAMSIZE $+\beta_{6}$ AVHHINC $+\beta_{7}$ CHILD $+\beta_{8}$ RESOURCE +

$\beta_{9}$ TRADITN $+\beta_{10}$ FMOBJECT $+\beta_{11}$ SEGREG $+\beta_{12}$ STATUS $+\epsilon_{1} \ldots \ldots$ (B)

Where:

$P_{i}$ : the probability of either working or not (models $A / 1, A / 2, A / 3$, and $A / 4)$; or working at home or outside the home (model B)

$\beta_{1}: \quad \operatorname{logit}$ coefficients

$\epsilon_{\mathrm{i}}$ : error term.

VARIABLE DEFINITION

Dependent Variable

A woman's participation in economic activity is the dependent variable. It is coded " 1 " if a woman is working, and "o" if not working. This is applied in the first run of the four models that include the demographic and socioeconomic variables. In the second run, which incorporates cultural variables, the model includes only the working women. In this case, the dependent variable indicates a woman's work at home, coded "1," or outside the home, coded "0."

\section{Independent Variables}

The independent variables are grouped into three categories, demographic variables, socio-economic variables, and cultural variables. 
1. Demographic variables:

1.1 Marital status: in the pooled sample model, marital status is dichotomous; where the value of "0" is assigned to single women, and "l" to evermarried (currently-married and previously-married) women. In the ever-married women's model, "I" is assigned to the currently-married women, and "O" to the previously-married (widowed, divorced or separated) women.

1.2 Age: is a continuous variable, indicating the respondent's age, starting with age 15 onward.

1.3 Family size: calculated in terms of equivalent consumer adult units, where every two children equal one adult.

1.4 Preschool child care burden: indicates the number of preschool age children (6 years and under) an ever-married woman has.

1.5 Resource person: is a dichotomous variable which indicates the presence " 1 " or absence "0" of a person who helps the mother (respondent) with the care of preschool age children. This variable is applicable to ever-married women only.

2. Socio-economic variables:

2.1 Respondent's education: is a continuous variable ranging from 0 to 16 . Illiteracy is denoted by "0"; 1-12 reflect the twelve grades of formal 
schooling, 13 and 14 reflect vocational training, 15 community college, and 16 reflects university education.

2.2 Education level of respondent's mother: is a continuous variable which uses the same levels as respondent's education.

2.3 Available household income: is the monthly household income in Jordanian Dinars (J.D.) excluding the respondent's income contribution.

3. Cultural variables:

3.1 Tradition: is a dichotomous variable whereby "1" reflects a woman's attitude towards her role as homemaker and childbearer, and "O" indicates the opposite.

3.2 Family objection: whereby a woman is constrained from undertaking economic activity or from working outside the home at a second level. It is a dichotomous variable whereby "1" indicates that there is family objection, and "0" that there is not.

3.3 Segregation: "1" indicates that the respondent works in a segregated place where there are only women working (or that the situation is inapplicable, e.g. When a woman works at home); "0" indicates that the woman works in a mixed environment. 
3.4 Status: is a dichotomous variable whereby "1" refers to a woman's perception that work and income contribution to her family give her better status and decision making ability within the household, and "O" indicates the opposite. 


\section{CHAPTER V}

\section{RESULTS}

There are four parts to this chapter. Part I presents simple distributions of the respondents across various categories. Part II presents comparisons between men and women. Part III constitutes preliminary comparisons between two groups of women: working versus non-working, and working at home versus working outside the home. Finally, in Part IV, the results of the multivariate logit model, analyzing factors affecting women's decision to participate in economic activity, are presented.

\section{PART I: RESPONDENTS ' DISTRIBUTION}

This section includes tables for all women in the study sample. Table I shows that 51\% of the total sample are married, followed by $39.8 \%$ who are single. The smallest percentage appears for women who are in the previouslymarried category at 9.2\%. Previously-married women are those who are either widowed, divorced or separated. The mean age for all women is 33 years and the median 27 years, which means that half the women are between the age of 15 and 27 . 
TABLE I

PERCENTAGE DISTRIBUTION OF FEMALE RESPONDENTS BY AGE GROUP AND MARITAL STATUS

\begin{tabular}{|c|c|c|c|c|}
\hline AGE GROUP & SINGLE & $\begin{array}{l}\text { CURRENTLY } \\
\text { MARRIED }\end{array}$ & $\begin{array}{l}\text { PREVIOUSLY } \\
\text { MARRIED }\end{array}$ & $\begin{array}{l}\text { ROW } \\
\text { TOTAL }\end{array}$ \\
\hline $15-19$ & $\begin{array}{l}94.5 \\
49.7\end{array}$ & $\begin{array}{l}5.5 \\
2.3\end{array}$ & $\begin{array}{l}0.0 \\
0.0\end{array}$ & 20.9 \\
\hline $20-24$ & $\begin{array}{l}60.6 \\
32.9 \\
\end{array}$ & $\begin{array}{l}39.4 \\
16.7 \\
\end{array}$ & $\begin{array}{l}0.0 \\
0.0 \\
\end{array}$ & 21.6 \\
\hline $25-29$ & $\begin{array}{l}37.5 \\
12.1 \\
\end{array}$ & $\begin{array}{l}57.1 \\
14.4\end{array}$ & $\begin{array}{l}5.4 \\
7.5 \\
\end{array}$ & 12.9 \\
\hline $30-34$ & $\begin{array}{r}19.4 \\
4.0 \\
\end{array}$ & $\begin{array}{l}69.4 \\
11.3 \\
\end{array}$ & $\begin{array}{l}11.1 \\
10.0 \\
\end{array}$ & 8.3 \\
\hline $35-39$ & $\begin{array}{r}4.5 \\
.6 \\
\end{array}$ & $\begin{array}{r}90.9 \\
9.0 \\
\end{array}$ & $\begin{array}{l}4.1 \\
2.5 \\
\end{array}$ & 5.1 \\
\hline $40-44$ & $\begin{array}{l}0.0 \\
0.0 \\
\end{array}$ & $\begin{array}{l}96.0 \\
10.8 \\
\end{array}$ & $\begin{array}{l}4.0 \\
2.5 \\
\end{array}$ & 5.7 \\
\hline $45-49$ & $\begin{array}{r}3.3 \\
.6 \\
\end{array}$ & $\begin{array}{l}86.7 \\
11.7 \\
\end{array}$ & $\begin{array}{r}10.0 \\
7.5 \\
\end{array}$ & 6.9 \\
\hline $50-54$ & $\begin{array}{l}0.0 \\
0.0 \\
\end{array}$ & $\begin{array}{l}92.6 \\
11.3 \\
\end{array}$ & $\begin{array}{l}7.4 \\
5.0 \\
\end{array}$ & 6.2 \\
\hline $55-59$ & $\begin{array}{l}0.0 \\
0.0 \\
\end{array}$ & $\begin{array}{r}65.0 \\
5.9 \\
\end{array}$ & $\begin{array}{l}35.0 \\
17.5 \\
\end{array}$ & 4.6 \\
\hline $60+$ & $\begin{array}{l}0.0 \\
0.0\end{array}$ & $\begin{array}{r}44.1 \\
6.8 \\
\end{array}$ & $\begin{array}{l}55.9 \\
47.5 \\
\end{array}$ & 7.8 \\
\hline Total & 39.8 & 51.0 & 9.2 & 100.0 \\
\hline
\end{tabular}

Married women are prevalent in all age categories. In contrast, the single women concentrate in the younger age brackets up to age 34 . The previously-married women appear in the higher age brackets starting at age group 25-29. Half of the single women are in the youngest age group 
(15-19), and in contrast, almost half (47.5\%) of the previously-married women are in the oldest age group $(60+)$. The previously-married group ( 40 women) consists of $80 \%$ widows, $15 \%$ divorced, and $5 \%$ separated women. The mean age is 56 years; median 57 and mode 50 years. Seventy percent of them are illiterate. The employment status shows that $30 \%$ of them work; $10 \%$ do not work, but wish to work; $7.5 \%$ do not work and do not wish to work; $10 \%$ are ill; and the highest percentage (42.5\%) are too old to work.

More than a quarter of the sample are illiterate (26.7\%) (Table II). Among those, the highest percent appears for the married women (73.3\%) followed by the previously-married women (24.1\%). The secondary education level accounts for $23.2 \%$ of the women, followed by the preparatory level which accounts for $21.4 \%$. In other words, almost half the women (44.6\%) have preparatory or secondary education. Indeed, the median falls at the second preparatory level. Those with post-secondary education, i.e. community college, vocational training or university education, account for only $12 \%$ of the total. It is also worth noting that the majority of university level women (80\%) are in the single category. 
TABLE II

PERCENTAGE DISTRIBUTION OF FEMALE RESPONDENTS BY EDUCATION LEVEL

$(\mathrm{N}=435)$

\begin{tabular}{|c|c|c|c|c|}
\hline $\begin{array}{l}\text { EDUCATION } \\
\text { LEVEL }\end{array}$ & SINGLE & $\begin{array}{l}\text { CURRENTLY } \\
\text { MARRIED }\end{array}$ & $\begin{array}{l}\text { PREVIOUSLY } \\
\text { MARRIED }\end{array}$ & $\begin{array}{l}\text { ROW } \\
\text { TOTAL }\end{array}$ \\
\hline Illiterate & $\begin{array}{l}2.6 \\
1.7 \\
\end{array}$ & $\begin{array}{l}73.3 \\
38.3 \\
\end{array}$ & $\begin{array}{l}24.1 \\
70.0 \\
\end{array}$ & 26.7 \\
\hline Elementary & $\begin{array}{r}21.9 \\
9.2 \\
\end{array}$ & $\begin{array}{l}67.1 \\
22.1 \\
\end{array}$ & $\begin{array}{l}11.0 \\
20.0 \\
\end{array}$ & 16.8 \\
\hline Preparatory & $\begin{array}{l}51.6 \\
27.7 \\
\end{array}$ & $\begin{array}{l}48.4 \\
20.3 \\
\end{array}$ & & 21.4 \\
\hline Secondary & $\begin{array}{l}67.3 \\
39.3 \\
\end{array}$ & $\begin{array}{l}31.7 \\
14.4 \\
\end{array}$ & $\begin{array}{l}1.0 \\
2.5 \\
\end{array}$ & 23.2 \\
\hline $\begin{array}{l}\text { Community } \\
\text { College }\end{array}$ & $\begin{array}{l}72.3 \\
19.7 \\
\end{array}$ & $\begin{array}{r}23.4 \\
5.0 \\
\end{array}$ & $\begin{array}{l}4.3 \\
5.0 \\
\end{array}$ & 10.8 \\
\hline University & $\begin{array}{r}80.0 \\
2.3 \\
\end{array}$ & & $\begin{array}{r}20.0 \\
2.5 \\
\end{array}$ & 1.1 \\
\hline $\begin{array}{l}\text { Column } \\
\text { Total }\end{array}$ & 39.8 & 51.0 & 9.2 & 100.0 \\
\hline
\end{tabular}

Table III shows that $30.4 \%$ of all women work. A quarter $(24 q)$ of the ones who work, work full-time as opposed to three quarters working part-time. By the classical definition of labor force as those who are working or seeking employment, the table shows that $54.3 \%$ are either actually working or wish to work. A group representing $17.9 \%$ of the women did not work and said they did not wish to work. However, they are classified in the eligible work force group, since they are neither students, nor ill or too old to work. 
TABLE III

EMPLOYMENT DISTRIBUTION OF THE FEMALE RESPONDENTS

\begin{tabular}{|lrrr||}
\hline & & & CUMULATIVE \\
\hline Nork Full-Time & 32 & 7.4 & 7.4 \\
Work Part-Time & 100 & 23.0 & 30.4 \\
No Work--Wish to Work & 104 & 23.9 & 54.3 \\
No Work--No Wish to Work & 78 & 17.9 & 72.2 \\
Student & 69 & 15.9 & 88.0 \\
Ill or Handicapped & 17 & 3.9 & 92.0 \\
Too old to Work & 35 & 8.0 & 100.0 \\
\hline Total & 435 & 100.0 & 100.0 \\
\hline
\end{tabular}

The students represent $15.9 \%$ of the total. These were excluded from the analysis of labor force, unless a student was working and reported economic activity and income.

Almost $4 \%$ of the women identified themselves as ill, and another $8 \%$ as too old to work. In fact, the category of "ill" was composed exclusively of women over sixty years of age. Sixty percent of these women were married, as opposed to $38.5 \%$ widowed and less than $2 \%$ separated. A quarter identified themselves as heads of their households; 56\% were wives of the head of household, and $19 \%$ were the mother of the head of household. They were mostly (95\%) illiterate. The ill and old women were excluded from the group of women who are eligible as a labor force. 
Employment Distribution by

Marital status

When cross-tabulating employment status with marital status for the total sample, it turns out that the majority of students (97\%) are single, versus $3 \%$ married (Table IV).

TABLE IV

EMPLOYMENT DISTRIBUTION OF FEMALE RESPONDENTS

BY MARITAL STATUS

$(\mathrm{N}=435)$

\begin{tabular}{|c|c|c|c|c|}
\hline $\begin{array}{l}\text { EMPLOYMENT } \\
\text { STATUS } \\
\end{array}$ & SINGLE & $\begin{array}{l}\text { CURRENTLY } \\
\text { MARRIED }\end{array}$ & $\begin{array}{l}\text { PREVIOUSLY } \\
\text { MARRIED } \\
\end{array}$ & $\begin{array}{l}\text { ROW } \\
\text { TOTAL } \\
\end{array}$ \\
\hline Work Full-Time & $\begin{array}{l}56.3 \\
10.4 \\
\end{array}$ & $\begin{array}{r}34.4 \\
5.0 \\
\end{array}$ & $\begin{array}{l}9.4 \\
7.5 \\
\end{array}$ & 7.4 \\
\hline Work Part-Time & $\begin{array}{l}26.0 \\
15.0 \\
\end{array}$ & $\begin{array}{l}65.0 \\
29.3 \\
\end{array}$ & $\begin{array}{r}9.0 \\
22.5 \\
\end{array}$ & 23.0 \\
\hline $\begin{array}{l}\text { No Work/ } \\
\text { Wish to Work }\end{array}$ & $\begin{array}{l}47.1 \\
28.3 \\
\end{array}$ & $\begin{array}{l}49.0 \\
23.0 \\
\end{array}$ & $\begin{array}{r}3.8 \\
10.0 \\
\end{array}$ & 23.9 \\
\hline $\begin{array}{l}\text { No Work/No } \\
\text { Wish to Work }\end{array}$ & $\begin{array}{r}16.7 \\
7.5 \\
\end{array}$ & $\begin{array}{l}79.5 \\
27.9 \\
\end{array}$ & $\begin{array}{l}3.8 \\
7.5 \\
\end{array}$ & 17.9 \\
\hline student & $\begin{array}{l}97.1 \\
38.7 \\
\end{array}$ & $\begin{array}{l}2.9 \\
0.9 \\
\end{array}$ & & 15.9 \\
\hline $\begin{array}{l}\text { Ill or } \\
\text { Handicapped }\end{array}$ & & $\begin{array}{r}76.5 \\
5.9 \\
\end{array}$ & $\begin{array}{l}23.5 \\
10.0 \\
\end{array}$ & 3.9 \\
\hline $\begin{array}{l}\text { Too old to } \\
\text { Work }\end{array}$ & & $\begin{array}{r}51.4 \\
8.1 \\
\end{array}$ & $\begin{array}{l}48.6 \\
42.5 \\
\end{array}$ & 8.0 \\
\hline Column Total & 39.8 & 51.0 & 9.2 & 100.0 \\
\hline
\end{tabular}

It is worth highlighting that the percentage of the women who are not working but wish to work is higher (23.9\%) than the women who are not working and do not wish to work (17.98). This has significant implications as to the potential that is available as a work force. 
The total sample (435 women) is divided into two groups (economically active versus inactive). Those who are actually working either full-time or part-time represent $30.4 \%$, and the rest (non-working) represent $69.6 \%$.

Table $\mathrm{V}$ shows that married women comprise the highest percentage of those who work among the three marital categories at $57.6 \%$ as opposed to $33.3 \%$ for the single women and 98 for the previously-married women. Only $25 \%$ of the single women are economically active, because the remainder (75\%) are students.

TABLE V

ECONOMIC ACTIVITY OF FEMALE RESPONDENTS BY MARITAL STATUS

$(\mathrm{N}=435)$

\begin{tabular}{||l|c|c|l|l||}
\hline \hline $\begin{array}{l}\text { EMPLOYMENT } \\
\text { STATUS }\end{array}$ & SINGLE & $\begin{array}{l}\text { CURRENTLY } \\
\text { MARRIED }\end{array}$ & $\begin{array}{l}\text { PREVIOUSLY } \\
\text { MARRIED }\end{array}$ & $\begin{array}{l}\text { ROW } \\
\text { TOTAL }\end{array}$ \\
\hline Working & $\begin{array}{l}33.3 \\
25.4\end{array}$ & $\begin{array}{l}57.6 \\
34.2\end{array}$ & $\begin{array}{r}9.1 \\
30.0\end{array}$ & 30.4 \\
\hline Non-Working & $\begin{array}{l}42.6 \\
74.6\end{array}$ & $\begin{array}{l}48.2 \\
65.8\end{array}$ & $\begin{array}{r}9.2 \\
70.0\end{array}$ & 69.6 \\
\hline Column Total & 39.8 & 51.0 & 9.2 & 100.0 \\
\hline
\end{tabular}

When the students and the women who are either ill or too old to work are excluded from the sample population, since they are ineligible as a work force, the remainder "eligible or potential work force" consists of 314 women, $72 \%$ of the total. The distribution for the eligible group of women shows that the percentage of those working rises 
from $30.4 \%$ for the total sample to $42 \%$ in the eligible group (see Table VI).

TABLE VI

ECONOMIC ACTIVITY OF THE ELIGIBLE FEMALES

BY MARITAL STATUS

$(\mathrm{N}=314)$

\begin{tabular}{||l|c|c|c|c||}
\hline $\begin{array}{l}\text { EMPLOYMENT } \\
\text { STATUS }\end{array}$ & SINGLE & $\begin{array}{l}\text { CURRENTLY } \\
\text { MARRIED }\end{array}$ & $\begin{array}{l}\text { PREVIOUSLY } \\
\text { MARRIED }\end{array}$ & $\begin{array}{l}\text { ROW } \\
\text { TOTAL }\end{array}$ \\
\hline Working & $\begin{array}{l}33.3 \\
41.5\end{array}$ & $\begin{array}{l}57.6 \\
40.2\end{array}$ & $\begin{array}{r}9.1 \\
63.2\end{array}$ & 42.0 \\
\hline Non-Working & $\begin{array}{l}34.1 \\
58.5\end{array}$ & $\begin{array}{l}62.1 \\
59.8\end{array}$ & $\begin{array}{r}3.8 \\
36.8\end{array}$ & 58.0 \\
\hline Column Total & 33.8 & 60.2 & 6.1 & 100.0 \\
\hline
\end{tabular}

Table VII shows that almost $73 \%$ of the working women engage in embroidery and sewing, which are activities usually carried out at home. Certain occupations such as teacher or nurse are known to be formal sector jobs. In contrast, other occupations, e.g. hairdresser, could be classified as belonging to either the formal or the informal sector. Using an arbitrary distribution of women's work into formal versus informal sector activities shows that the majority of women $(87.7 \%)$ engage in informal sector-type activities. Those engaging in formal sector activities comprise $12.3 \%$ (Table VII).

Ninety-two percent of the working women reported only one occupation. The remainder had second occupations that 
indicated informal sector-type activities, mostly embroidery and sewing.

TABLE VII

OCCUPATIONAL DISTRIBUTION OF

WORKING WOMEN

\begin{tabular}{|lrr|}
\hline & & \\
& NUMBER & $\%$ \\
\hline Informal: & & \\
Embroidery & 89 & 67.4 \\
Sewing & 7 & 5.3 \\
Supervisor & 8 & 6.1 \\
Enterprise Owner & 1 & 0.7 \\
Hairdresser & 2 & 1.5 \\
Janitor/Cleaner & 9 & 6.8 \\
Formal: & & \\
Teacher & & \\
Government Employee & 8 & 6.1 \\
Secretary & 2 & 1.5 \\
Nurse/Paramedical Staff & 3 & 2.3 \\
Factory Laborer & 1 & 0.8 \\
& 2 & 1.6 \\
\hline Total & & 100.0 \\
\hline
\end{tabular}

The percentage of women who worked at home was $68 \%$ as compared to $17 \%$ working in the neighborhood, and $15 \%$ working in Amman (beyond the immediate community).

Among the 104 women who were not working and said they wished to work, $78 \%$ had not applied for a job. Fifteen percent of the job seekers applied at the government civil Service office, $2 \%$ applied at the Ministry of Labor Employment office which provides jobs in the private sector, and $5 \%$ applied at different non-governmental agencies. The 
reason the majority of women who wished to work did not actively pursue employment, they said, was due to their reliance on personal contact to find employment, through relatives or acquaintances within their neighborhoods. They are among the lesser educated women, and therefore know a priori their limited chances of employment in the organized labor market. Half of them wished to work at home, and the other half did not mind working outside the home. As for the desired occupation, the majority (54\%) of the women indicated embroidery, sewing and other handicrafts. The second highest occupation sought (14\%) was that of teacher. The rest of the desired occupations were distributed almost equally between formal and informal sector-type activities.

\section{PART II: COMPARISON BETWEEN WOMEN AND MEN IN THE SAMPLE POPULATION}

The mean and median in Table VIII show similar education levels for the women and men in the sample. However, the striking difference is in the proportion of illiterates among the genders. While only 98 of the males are illiterate, almost $27 \%$ of the females are illiterate. For married women, the questionnaire established categories of first and second wife, to depict the extent of polygamy. Three percent of married women were in polygamous marriages, either as first or second wife. Among the total female sample, very few were divorced at $0.5 \%$ or separated at $1.4 \%$. Comparing the marital status of men and women 
(Table IX) shows that the majority of women are married, while the majority of men are single.

TABLE VIII

AGE AND EDUCATION COMPARISON

\begin{tabular}{|ccc|}
\hline & & \\
\hline Age (years) & & MALE \\
mean & 33 & 32 \\
median & 27 & 25 \\
Education & & \\
mean & & 9 th grade \\
median & 7 th grade & 9 th grade \\
Percent Illiterate & 8 th grade & $9.0 \%$ \\
\hline
\end{tabular}

TABLE IX

PERCENTAGE DISTRIBUTION OF

MARITAL STATUS

\begin{tabular}{|lcc|}
\hline & & \\
& FEMALE & MALE \\
\hline Single & 39.8 & 54.1 \\
Married & 51.0 & 44.7 \\
Widow(ed) & 7.4 & 0.8 \\
Divorced & 1.4 & 0.4 \\
Separated & 0.5 & 0.0 \\
& $100 \%$ & 1008 \\
\hline
\end{tabular}


While $64.8 \%$ of the men work, only 30.48 of females do so. Among the total working males, a negligible $4 \frac{8}{6}$ work part-time, whereas the majority of the working females (76\%) work part-time (Table $x$ ). As mentioned earlier, part-time work for women basically means working at home during leisure time.

TABLE X

EMPLOYMENT STATUS COMPARISON

\begin{tabular}{|lcc|}
\hline & & \\
\hline EMPLOYMENT STATUS & FEMALE 8 & MALE $q$ \\
\hline Working Full-Time & 7.4 & 62.1 \\
Working Part-Time & 23.0 & 2.7 \\
Unemployed; Seek work & 23.9 & 10.3 \\
Student & 15.9 & 18.1 \\
Ill or Handicapped & 3.9 & 3.1 \\
Too old to Work & 8.0 & 3.7 \\
Not Working ("C") & 18.0 & ---- \\
\hline
\end{tabular}

of particular significance is the percentage of women wishing to work at $24 \%$ versus $10 \%$ among the males. This may be due to a higher percentage among the males who are actually working, also the higher percentage among males who are students. This may also be due to an array of other factors. Although males have on average a little more education than females ( 9 th grade versus 7 th grade), they have better mobility and access to the labor market and 
consequently seek employment more actively than women. Other factors include labor-market supply and available job types that may not be considered appropriate for women. Women may also find work outside the home as incompatible with their domestic and child-care responsibilities. It is worth highlighting the wide disparity in earned income between men and women, also the wider variety of men's than women's occupations (Table XI). For men the highest incidence of a specific occupation is that of laborer and other occupations that do not require high levels of education (Table XII). The majority of men ( $98 \%$ ) did not have second occupations. The remainder had second occupations such as laborer, mechanic, electrician or private tutors.

TABLE XI

INCOME COMPARISON

\begin{tabular}{|cll|}
\hline Monthly Work Income (in J.D.): & Female & Male \\
\hline & & \\
mean & 29.000 & 116.700 \\
median & 17.500 & 100.000 \\
mode & 10.000 & 100.000 \\
\hline
\end{tabular}


TABLE XII

DISTRIBUTION OF MEN'S OCCUPATIONS

\begin{tabular}{|c|c|c|}
\hline Men's Occupations & Number & $q$ \\
\hline Laborer & 60 & 19.0 \\
\hline Construction laborer & 31 & 9.8 \\
\hline Salesman & 29 & 9.2 \\
\hline Driver/taxi & 22 & 7.0 \\
\hline Driver/truck & 19 & 6.0 \\
\hline Government employee & 18 & 5.7 \\
\hline Teacher & 12 & 3.8 \\
\hline Private sector employee & 11 & 3.5 \\
\hline Mechanic & 11 & 3.5 \\
\hline Carpenter & 10 & 3.2 \\
\hline Janitor/cleaner & 10 & 3.2 \\
\hline Merchant & 10 & 3.2 \\
\hline Enterprise owner & 10 & 3.2 \\
\hline Electrician & 8 & 2.5 \\
\hline Restaurant/Hotel worker & 8 & 2.5 \\
\hline Contractor & 5 & 1.6 \\
\hline Guard & 5 & 1.6 \\
\hline Small Factory owner & 4 & 1.3 \\
\hline Supervisor & 4 & 1.3 \\
\hline Accountant/cashier & 4 & 1.3 \\
\hline Restaurant/Hotel owner & 3 & 1.0 \\
\hline Tailor & 3 & 1.3 \\
\hline Bank employee & 2 & 0.6 \\
\hline Computer operator/Admin. & 2 & 0.6 \\
\hline Nurse/paramedical staff & 2 & 0.6 \\
\hline Factory laborer & 2 & 0.6 \\
\hline School director & 1 & 0.3 \\
\hline Lawyer & 1 & 0.3 \\
\hline Company worker & 1 & 0.3 \\
\hline Barber & 1 & .3 \\
\hline other & 5 & 1.6 \\
\hline Total & 315 & 100.0 \\
\hline
\end{tabular}


PART III: COMPARISON BETWEEN WORKING AND NON-WORKING ELIGIBLE WOMEN

The 314 eligible women were segregated into two groups, the working and the non-working women. T-tests were run on the various demographic and socio-economic variables to test whether there are significant differences between the two groups. Table XIII shows significant differences in age and available household income at the .001 significance level, and education at the .05 level.

TABLE XIII

DIFFERENCE OF MEANS ANALYSIS

(ELIGIBLE WOMEN; $\mathrm{N}=314$ )

\begin{tabular}{||l|c|c||}
\hline \multicolumn{2}{||c|}{ Eligible Non-working $(n=182) /$ Eligible Working $(n=132)$} \\
\hline VARIABLE & t-VALUE & p-VALUE \\
\hline Education & -4.33 & .000 \\
\hline $\begin{array}{l}\text { Mother's } \\
\text { Education }\end{array}$ & 2.31 & .021 \\
\hline $\begin{array}{l}\text { Family Size } \\
\text { Household Income }\end{array}$ & -0.17 & .862 \\
\hline
\end{tabular}

For the currently and previously-married women, there was a significant difference between the two groups in the presence of a resource person (Table XIV). For the currently-married women, variables relating to the husband's education and income were tested (Table XV). There was a 
significant difference between the two groups of working and non-working women in the level of husband's education. However, there was no difference regarding the husband's income.

TABLE XIV

DIFFERENCE OF MEANS ANALYSIS

(EVER-MARRIED WOMEN; $\mathrm{N}=208$ )

\begin{tabular}{||c|c|c|}
\hline \multicolumn{3}{|c|}{$\begin{array}{c}\text { EVER-MARRIED WOMEN: CURRENTLY- \& PREVIOUSLY-MARRIED } \\
\text { Eligible Non-Working }(\mathrm{n}=120) / \text { Eligible Working (n=88) }\end{array}$} \\
\hline VARIABLE & t-VALUE & p-VALUE \\
\hline Child & 1.48 & .141 \\
\hline Resource Person & -2.67 & .008 \\
\hline Age at Marriage & 0.17 & .866 \\
\hline
\end{tabular}

TABLE XV

\section{DIFFERENCE OF MEANS ANALYSIS (CURRENTLY- MARRIED WOMEN; $\mathrm{N}=189$ )}

\begin{tabular}{|c|c|c|}
\hline \multicolumn{3}{|c|}{ CURRENTLY-MARRIED WOMEN } \\
Eligible Non-Working $(\mathrm{n}=113) /$ El igible Working $(\mathrm{n}=76)$ \\
\hline VARIABLE & t-VALUE & p-VALUE \\
\hline Husband's Education & 2.24 & .026 \\
\hline Husband's Income & 1.51 & .134 \\
\hline
\end{tabular}

The working women in the pooled sample were segregated into two groups: those working in the home, and those working outside the home $(\mathrm{N}=314)$. Education was the only 
variable that showed a significant difference between the two groups of working women (see Table XVI).

TABLE XVI

DIFFERENCE OF MEANS ANALYSIS

(WORKING WOMEN; $\mathrm{N}=132$ )

\begin{tabular}{||l|c|c||}
\hline \multicolumn{2}{|c|}{ WORKING WOMEN: AT HOME $(\mathrm{n}=94)$ /OUTSIDE THE HOME (n=38) } \\
\hline VARIABLE & t-VALUE & p-VALUE \\
\hline Age & -1.30 & .195 \\
Education & 3.01 & .003 \\
\hline \multirow{2}{*}{ Mother's Education } & -0.56 & .579 \\
\hline Family Size & 0.61 & .545 \\
\hline Household Income & -0.50 & .619 \\
\hline
\end{tabular}

The cultural variables are dichotomous. Crosstabulating the four cultural variables with a woman's state of working inside the home versus working outside the home showed significant effects for the first three variables, namely tradition, family objection and segregation (Table XVII) • 
TABLE XVII

DIFFERENCE IN CULTURAL ATTITUDES

(WORKING WOMEN; $N=132$ )

\begin{tabular}{||l|c|c||}
\hline \multicolumn{3}{|c|}{$\begin{array}{r}\text { WORKING WOMEN : AT HOME }(\mathrm{n}=94) / \\
\text { OUTSIDE THE HOME }(\mathrm{n}=38)\end{array}$} \\
\hline CULTURAL VARIABIE & CHI SQUARE & SIGNIFICANCE \\
\hline Tradition & 8.42553 & .00370 \\
\hline Family Objection & 15.69462 & .00007 \\
\hline Segregation & 28.38084 & .00000 \\
\hline Status & 0.09150 & .76228 \\
\hline
\end{tabular}

Difference-of-means tests and cross-tabulations were run above for the two groups of working and non-working women, and for the women who work at home versus those who work outside the home. These tests determine the significant variables that will be included in the logit models.

Demographic variables: age, family size (measured in equivalent adult consumer units), number of children, and resource person.

Socio-economic variables: education, available household income, for all women; and husband's income and education in a separate run for the currently-married women. 
Cultural variables: tradition, family objection, and segregation.

\section{PART IV: RESULTS OF THE MULTIVARIATE}

ANALYSIS

The Pooled Sample Logit

Model

Table XVIII displays the results associated with the pooled sample (model 1/A). The table displays the logit model associated with the decision to work or not to work (the dichotomous dependent variable). The hypothesis posed is that this decision is determined mainly by socio-economic and demographic characteristics (age, education, family size, household income, number of children under the age of six, presence of a resource person in the household, and marital status). In the pooled sample, marital status is included as a predictor variable, where the value of "o" indicates that the woman is single, and "1" indicates that a woman is currently-married or has been married (widowed, divorced or separated).

Age, household income, resource person and marital status showed significant relationships with the decision to participate in the labor force. The older the woman, the more likely she is to participate in the labor force. As expected, the higher the family income, the less likely that a woman will participate in the labor force. Also marital status had a significant effect. As expected, single women 
are more likely than ever-married women to participate in economic activity.

TABLE XVIII

POOLED SAMPLE OF DEMOGRAPHIC AND SOCIO-ECONOMIC VARIABLES

\begin{tabular}{|c|c|c|c|}
\hline \multicolumn{4}{|c|}{$\begin{array}{l}\text { Number of Observations: } 314 \\
\text { (Working=132/Non-Working }=182 \text { ) }\end{array}$} \\
\hline VARIABLE & $\begin{array}{l}\text { ESTIMATED } \\
\text { COEFFICIENT }\end{array}$ & T-RATIO & $\begin{array}{l}\text { ELASTICITY } \\
\text { AT MEANS }\end{array}$ \\
\hline Age & $0 \% 07789$. & 4.1290 & $1 /, 4861$. \\
\hline Education & 0.0309 & 0.83882 & 0.13228 \\
\hline Av1 $\mathrm{HH}: \mathrm{Incone}$ & $=0.0927$ & 22.5129 & $10 \% 39659$ \\
\hline Family size & 0.0020 & 0.03530 & 0.00871 \\
\hline 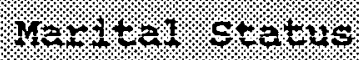 & 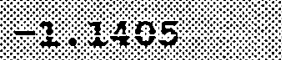 & $12+5,35$ & $=3.44799$. \\
\hline Child & 0.0296 & 0.21055 & 0.01439 \\
\hline Resour & 1,20110 & 2.2149 & 0.004535 \\
\hline
\end{tabular}

Constant: -1.7966

Percentage of right predictions: 0.66

The presence of a resource person increases the likelihood of a woman to work. However, contrary to our expectation, the variable "child" did not show any 
significant relationship with the dependent variable. The simple correlation coefficient between the child and resource variables was significant at the .001 level. Thus the impact of the child variable was overshadowed by the resource variable, due to collinearity.

Table XVIII also reports the elasticities at the means. This is a good measure for interpreting and understanding the effect of the various explanatory variables on the probability of undertaking the action under study. These figures indicate the amount of percentage change in the probability of participating in the labor force for a $1 \%$ change in the value of the explanatory variable from its average value. For example, $1 \frac{q}{8}$ increase in "age" will increase the probability of participation in the labor force by $1.48 \%$, or a woman whose age is $1 \%$ higher than the average age of the group is $1.48 \%$ more likely to work, ceteris paribus. Similarly a $1 \%$ increase in available household income will decrease a woman's probability of participation by $0.4 \%$, ceteris paribus.

The model may be used to estimate the probability of an "average" woman participating in the labor force by substituting the average values for the explanatory variables in the following logit function: $P_{i}=1 /(1+e-(-1.80+0.079$ AGE +0.031 EDUC -0.003 AVLHHINC +0.002 FAMSIZE +0.029 CHILD + 1.201 RESOURCE - 1.141 MARTTAL) ( $(1 / A)$ 
Both the resource and marital status variables are dichotomous. For resource, it indicates the presence or absence of a resource person to help the ever-married woman in household chores and child care. In the case of single women, the resource variable is implicitly inapplicable. For marital status, "0" indicates never-married, i.e. single women, and " 1 " ever-married, i.e. currently and previouslymarried women. The substitution for these dichotomous variables yields the following results:

Average Single Woman:

$P_{i}=1 /(1+e-(-1.80+0.079(31.75)+0.031(7.2)-0.003(243.3)+0.002(7.34)+0.029(0.82)+$ $1.201(0)-1.141(0))$

Average Ever-Married Woman/No Resource:

$P_{i}=1 /(1+e-(-1.80+0.079(31.75)+0.031(7.2)-0.003(243.3)+0.002(7.34)+0.029(0.82)+$ $1.201(0)-1.141(1))$

Average Ever-Married Woman/With Resource:

$P_{i}=1 /(1+e-(-1.80+0.079(31.75)+0.031(7.2)-0.003(243.3)+0.002(7.34)+0.029(0.82)+$ $1.201(1)-1.141(1))$

Table XIX shows that the probability that the average single woman would work is 56\%, and the probability for the average ever-married woman without a resource person to work is $29 \%$. Hence, the impact of being single is 27 percentage points. In other words, the ever-married woman is 27 percentage points less likely to work than the single woman. 
TABLE XIX

IMPACT OF MARITAL STATUS

\begin{tabular}{|l|c|c||}
\hline MARITAL STATUS/RESOURCE & PROBABILITY & IMPACT \\
\hline Single/No Resource & 55.97 & \\
\hline Ever-Married/No Resource & 28.91 & $27.06 \%$ \\
\hline Ever-Married/Resource & 57.45 & $28.54 \%$ \\
\hline
\end{tabular}

The probability that the average ever-married woman with a resource person would work is 57\%, while it is $29 \%$ for the ever-married woman without a resource person. Therefore the impact of the presence of a resource person is 28.5 percentage points; or an ever-married woman with a resource person is 28.5 percentage points more likely to work than an ever-married woman without a resource person. overall, the model predictability, as measured by the percentage of cases in the pooled sample predicted correctly, is slightly over $65 \%$.

\section{Single women Logit Model}

For the single women, age was the only variable that showed a significant relationship with the decision to participate in economic activity (see Table XX). The elasticity at the mean shows that $1 \%$ increase in AGE will 
increase the probability of participation in the labor force by $2.83 \%$, ceteris paribus.

TABLE XX

SINGLE WOMEN SAMPLE: DEMOGRAPHIC AND SOCIO-ECONOMIC VARIABLES

\begin{tabular}{|c|c|c|c|}
\hline \multicolumn{4}{|c|}{$\begin{array}{l}\text { Number of Observations: } 106 \\
\text { (Working }=44 / \text { Non-Working }=62 \text { ) }\end{array}$} \\
\hline VARIABLE & $\begin{array}{l}\text { ESTIMATED } \\
\text { COEFFICIENT }\end{array}$ & T-RATIO & $\begin{array}{l}\text { ELASTICITY } \\
\text { AT MEANS }\end{array}$ \\
\hline fige & 0.2103 & $3.617 \%$ & 2.8250 \\
\hline Education & -0.02464 & -0.4103 & -0.1460 \\
\hline Avl HH Income & -0.0011 & -0.6473 & -0.1647 \\
\hline Family size & 0.0358 & 0.3484 & 0.1672 \\
\hline
\end{tabular}

Constant: $\quad-4.9173$

Percentage of Right Predictions: 0.72

The willingness of older unmarried women to maintain economic activity may be interpreted as follows:

1. She may have more time on her hands than the married woman who has the main responsibility of household chores and child care.

2. The single, unmarried woman may work to cover her own expenses, and alleviate the financial obligation of the family towards her. 
However, contrary to expectation, education did not seem to have any significant effect on a single woman's decision to undertake economic activity. since age has a positive effect on the single woman's decision to work, and since older women have lower education levels (negative correlation coefficient between age and education), this finding may be a result of women's work in informal-type activities that do not require high levels of education.

As hypothesized, family income had a negative, though insignificant, effect on the single woman's decision to work. The reason other variables did not show significant relationships was probably due to collinearity (the simple correlation coefficient between family size and income was significant at the .001 level). Overall, the percentage of right predictions in this model is $72 \%$.

\section{Ever-Married Women Logit} Model

For the ever-married women (Table XXI), age, available household income and the presence of a resource person showed significant relationships with the decision to participate in the economic activity. Age and household income were in line with the findings for the pooled sample; age had a positive relationship with the decision to work, and household income had a negative relationship. The presence of a resource person increased the likelihood of an ever-married woman to undertake economic activity. 
TABLE XXI

EVER-MARRIED WOMEN SAMPLE: DEMOGRAPHIC AND
SOCIO-ECONOMIC VARIABLES

\begin{tabular}{|c|c|c|c|}
\hline \multicolumn{4}{|c|}{$\begin{array}{l}\text { Number of Observations: } 208 \\
\text { (Working }=88 / \text { Non-Working }=120 \text { ) }\end{array}$} \\
\hline VARIABLE & $\begin{array}{l}\text { ESTIMATED } \\
\text { COEFFICIENT }\end{array}$ & T-RATIO & $\begin{array}{l}\text { ELASTICITY } \\
\text { AT MEANS }\end{array}$ \\
\hline igan & 040582. & 28.851. & $3.260 \%$. \\
\hline Education & 0.0215 & 0.4128 & 0.0734 \\
\hline Avi. int I Income & $1.0 \% .00444$ & $=2.8025$ & .0 .6385 \\
\hline Family size & 0.0227 & 0.3152 & 0.0947 \\
\hline Child & -0.0559 & -0.3870 & -0.0410 \\
\hline Resourrace & 1.2659 & $2.2969:$ & 0.0724. \\
\hline Marital1 & -0.6824 & -1.1770 & -0.3689 \\
\hline
\end{tabular}

Constant: -1.1541

Percentage of Right Predictions: 0.67

The impact of the child variable is again overshadowed by the resource variable as the simple correlation coefficient between the two variables was significant at the .01 level. Also the impact of the family size variable is overshadowed by 
household income, since the two variables have a simple correlation coefficient that is significant at the .001 level. Marital status did not show any significant effect on the decision to work. The simple correlation test showed marital status to have significant correlation effects with the age and child variables. This may explain the lack of effect of the marital status variable on the dependent variable in the ever-married women's model.

To estimate the probability of an "average" ever-married woman to participate in the labor force, we substitute the average values for the explanatory variables in the following logit function:

$P_{i}=1 /(1+e-(-1.154+0.058$ AGE +0.022 EDUC - 0.004 AVLHHINC +0.023 FAMSIZE -0.06 CHILD + 1.27 RESOURCE - 0.68 MARTAL(1)

Table XXII shows that the impact of the marital status on the woman's likelihood to work is 16.7 percentage points more for the previously-married woman than the currentlymarried woman without the presence of a resource person, and 13 percentage points more with the presence of a resource person. Thus the previously-married woman is more likely to work than the currently-married woman in both cases whether she did or did not have a resource person. Overall, the model predictability, as measured by the percentage of cases predicted correctly in the ever-married women's sample, is $67 \%$. 
TABLE XXII

IMPACT OF MARITAL STATUS ON WOMAN'S LIKELIHOOD TO WORK

\begin{tabular}{|c|c|c|}
\hline $\begin{array}{l}\text { MARITAL STATUS/ } \\
\text { RESOURCE }\end{array}$ & PROBABILITY & $\begin{array}{l}\text { IMPACT } \\
\text { MARITAL }\end{array}$ \\
\hline 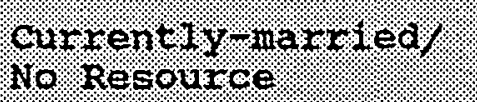 & 3.6 .59 & \\
\hline $\begin{array}{l}\text { Currently-married/ } \\
\text { Resource }\end{array}$ & 67.04 & \\
\hline 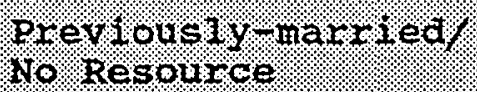 & 53.3 .1$. & 16.728 \\
\hline $\begin{array}{l}\text { Previously-married/ } \\
\text { Resource }\end{array}$ & 80.10 & 13.068 \\
\hline
\end{tabular}

Table XXIII shows that the probability that the average currently-married woman would work is $36.6 \%$ if she has no resource person as opposed to $67 \%$ if she has a resource person. Therefore a married woman is 30.5 percentage points more likely to work if she has the help of a resource person.

For the previously-married women, the probability of working if she had the help of a resource person is $80 \%$ while it is $53 \%$ if she did not have the help of a resource person. Hence the previously-married woman is 27 percentage points more likely to work if she had a resource person. 
TABLE XXIII

IMPACT OF RESOURCE PERSON

\begin{tabular}{|c|c|c|}
\hline MARITAL STATUS/RESOURCE & PROBABILITY & $\begin{array}{c}\text { IMPACT } \\
\text { RESOURCE } \\
\end{array}$ \\
\hline 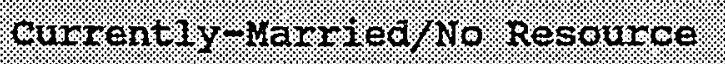 & 36.6 .59 & \\
\hline 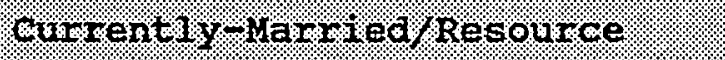 & $67 . \% 04$ & $30 \% 45 \%$ \\
\hline Previously-Married/No Resource & 53.31 & \\
\hline Previously-Married/Resource & 80.10 & 26.798 \\
\hline
\end{tabular}

To compare the single women's model (see Table XX) with the ever-married women's model (see Table XXI), we look at the elasticity at the means. Although the two models are not directly comparable, due to the presence of more variables in the case of the ever-married women's sample, general observations can be made. When age increases by $1 \%$, the probability of working increases by $1.26 \%$ for the evermarried women, as compared to $2.83 \%$ for the single women. In other words, when age increases by 1q, the change in the probability of working for the single women is double that for the ever-married women. 
Currently-Married Women

Logit Model

For the currently-married women (Table XXIV), the husband's education level and income had no significant relationships with the woman's decision to work. Age and the presence of a resource person showed significant relationships as was confirmed by the previous run for the ever-married women. Family size showed a significant negative relationship with the currently-married woman's decision to work, while household income did not. As expected, the larger the family size the less likely a married woman would work. In this model, household income is overshadowed by family size (the simple correlation coefficient between the two variables was significant at the .001 level). Overall, the percentage of right predictions in this model is $67 \%$.

The Pooled Working women

Sample (Including Cultural

Variables)

once a woman decides to undertake economic activity, the factors that are important in deciding whether to work at home or outside the home are believed to be governed by cultural considerations. Therefore, at this point we introduce the cultural variables in the second-phase nested logit. The hypothesis is that need may be the prime motivator of the decision to work, but cultural factors come into the picture in deciding where to work. 
TABLE XXIV

CURRENTLY-MARRIED WOMEN SAMPLE: DEMOGRAPHIC AND SOCIO-ECONOMIC VARIABLES

\begin{tabular}{|c|c|c|c|}
\hline \multicolumn{4}{|c|}{$\begin{array}{l}\text { Number of Observations: } 189 \\
\text { (Working }=76 / \text { Non-Working }=113 \text { ) }\end{array}$} \\
\hline VARIABLE & $\begin{array}{l}\text { ESTIMATED } \\
\text { COEFFICIENT }\end{array}$ & T-RATIO & $\begin{array}{c}\text { ELASTICITY } \\
\text { AT MEANS }\end{array}$ \\
\hline fase & 0.054 .3 & 2,0988 & 17,1889 \\
\hline Education & 0.0042 & 0.0694 & 0.0148 \\
\hline 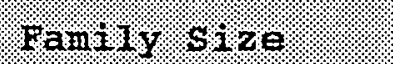 & 9.0 .138$. & $-2.294 .1 \%$ & $10.597 \%$ \\
\hline Husband Income & -0.0033 & -1.3640 & -0.2571 \\
\hline Husband Educatn & -0.0459 & -1.0058 & -0.2059 \\
\hline Child & 0.0993 & 0.6666 & 0.0803 \\
\hline Resoutirces & 3.38884 & $2.50,45$ & $0.085 \%$ \\
\hline
\end{tabular}

Constant: $\quad-0.96591$

Percentage of Right Predictions: 0.67

Table XXV shows the analysis of the second nested logit decision for the pooled sample of working women of whether to work at home or outside the home (model $2 / A$ ). 
TABLE XXV

POOLED SAMPLE: DEMOGRAPHIC, SOCIO-ECONOMIC AND CULTURAL VARIABLES

\begin{tabular}{|c|c|c|c|}
\hline \multicolumn{4}{|c|}{$\begin{array}{l}\text { Number of observations: } 132 \\
\text { (working: At home }=94 / \text { Outside home }=38 \text { ) }\end{array}$} \\
\hline $\begin{array}{c}\text { VARIABLE } \\
\text { NAME } \\
\end{array}$ & $\begin{array}{c}\text { ESTIMATED } \\
\text { COEFFICIENT } \\
\end{array}$ & T-RATIO & $\begin{array}{c}\text { ELASTICITY } \\
\text { AT MEANS } \\
\end{array}$ \\
\hline Age & -0.0350 & -0.7756 & -0.00005 \\
\hline Ecucation & $=0.22,40$ & $=2,6,377$ & -0.0 .0000 .6 \\
\hline Avl HH Income & 0.0018 & 0.6329 & 0.00002 \\
\hline Family size & -0.0831 & -0.5885 & -0.00002 \\
\hline Marital status & -0.1868 & -0.2809 & -0.00001 \\
\hline ortar. & 0.5492 & $1.808 \%$ & 0,00002 \\
\hline Resource & -0.8212 & -1.0099 & -0.00000 \\
\hline Tradition & 26.693 & 0.0002 & 0.0001 \\
\hline Family objection & 27.015 & 0.0003 & 0.0002 \\
\hline segregation & 3.4603. & $2.8591 \%$ & 0.0001 \\
\hline
\end{tabular}

Constant: $\quad-0.7245$

Percentage of Right Predictions: 0.85 
Table XXV indicates that education plays an important role in this decision; more educated women are less likely to work at home. The number of children under the age of six (CHILD) is also important (however, only at the $10 \%$ level of significance) in the decision of where to work. As the number of children under six increases so does the probability of working at home. Although our hypothesis has stipulated that the larger the number of children under six, the less likely a woman would work, it is interesting to find that the presence of preschool age children does not constrain a woman from undertaking economic activity, provided it is carried out in the home.

The only cultural variable that showed a significant result was segregation. This indicates that the higher the cultural constraint of working in a non-segregated (mixed) environment, the higher the probability of working at home.

To estimate the probability of an "average" woman to work at home, we substitute the average values for the (continuous) explanatory variables in the following logit function:

$P_{i}=1 /\left(1+e^{-(-0.725-0.035 \text { AGE }-0.224 \text { EDUC }+0.0018 \text { AVLHHINC }-0.0831 \text { FAMSIZE }+0.549 \text { CHILD }-~}\right.$ 0.821 RESOURCE - 0.187 MARTAL ++3.460 SEGREGATION) $) \quad(2 / \mathrm{A})$

$P_{1}=1 /\left(1+e^{-(-0.725-0.035(35.02)-0.224(6.46)+0.0018(210.8)-0.083(7.05)+0.549(0.72)-0.821}\right.$ RESOURCE - 0.187 MARTIAL + 3.460 SEGREGATION),

Substituting the values of "0" and " 1 " for the dichotomous variables (marital status, resource, 
segregation) yields the following results (see Table XXVI). This table shows that the probability of a single woman working at home if she has the segregation constraint is 56.3\%, while it is $51.6 \%$ for the married woman. Therefore, being single increases the probability of working at home by 4.6 percentage points for the segregation-inclined women.

The probability of a single woman working at home if she does not have the segregation constraint is $3.9 \%$, compared to $3.25 \%$ for the married woman. Therefore the impact of marital status at 0.61 percentage points is negligible, if women did not have the segregation constraint.

TABLE XXVI

IMPACT OF MARITAL STATUS ON WORKING AT HOME

\begin{tabular}{|c|c|c|}
\hline $\begin{array}{l}\text { MARITAL STATUS/ } \\
\text { RESOURCE/SEGREGATION }\end{array}$ & PROBABILITY & $\begin{array}{l}\text { IMPACT } \\
\text { MARITAL }\end{array}$ \\
\hline s. & 56.28 & \\
\hline $\begin{array}{l}\text { Single/ } \\
\text { No Segregation }\end{array}$ & 3.89 & \\
\hline 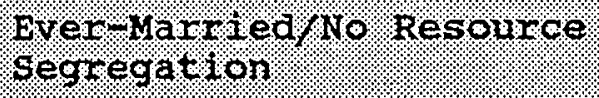 & 51.64. & 4.64 \\
\hline $\begin{array}{l}\text { Ever-Married/No Resource } \\
\text { No Segregation }\end{array}$ & 3.25 & 0.64 \\
\hline
\end{tabular}


Table XXVII shows that the probability of the "average" ever-married woman to work at home is the highest at $51.6 \%$ for the woman who has no resource person and who is inclined towards segregation. This compares to $31.9 \%$ probability for the ever-married woman who has a resource person and is also inclined towards segregation. Hence the impact of the presence of a resource person for the ever-married women with a segregation constraint is almost 20 percentage points.

The ever-married women who have no segregation barrier have a probability of working at home of $3.25 \%$ for the one with a resource person as compared to $1.45 \%$ for the woman without a resource person. Hence the impact of the resource person for this group of ever-married women without a segregation barrier is negligible at 1.8 percentage points. That could be due to the fact that the ever-married women without a segregation constraint are working already outside the home.

The probability of an "average" single woman working at home is $56.3 \%$ if she has the segregation constraint, compared to $3.9 \%$ if she did not have a segregation constraint (see Table XXVIII). Hence the impact of segregation for the single women is 52.4 percentage points. The single woman is 52.4 percentage points less likely to work at home if she had no segregation constraint. 
TABLE XVII

IMPACT OF RESOURCE

\begin{tabular}{|c|c|c|}
\hline $\begin{array}{l}\text { MARITAL STATUS/ } \\
\text { RESOURCE/SEGREGATION }\end{array}$ & PROBABIIITY & $\begin{array}{l}\text { IMPACT } \\
\text { RESOURCE }\end{array}$ \\
\hline Ever martegat lon & 31.96 & \\
\hline $\begin{array}{l}\text { Ever-Married/Resource } \\
\text { No Segregation }\end{array}$ & 1.45 & \\
\hline 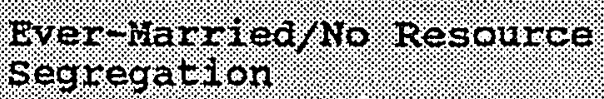 & 51.64 & 196,68 \\
\hline $\begin{array}{l}\text { Ever-Married/No Resource } \\
\text { No Segregation }\end{array}$ & 3.25 & 1.8 \\
\hline
\end{tabular}

TABLE XXVIII

IMPACT OF SEGREGATION

\begin{tabular}{|c|c|c|}
\hline $\begin{array}{l}\text { MARITAL STATUS/ } \\
\text { RESOURCE/SEGREGATION }\end{array}$ & PROBABILITY & $\begin{array}{l}\text { IMPACT } \\
\text { SEGREGATION }\end{array}$ \\
\hline $\begin{array}{l}\text { Single/ } \\
\text { Segregation }\end{array}$ & 56.28 & \\
\hline $\begin{array}{l}\text { Single/ } \\
\text { No Segregation }\end{array}$ & 3.89 & 52.39 \\
\hline 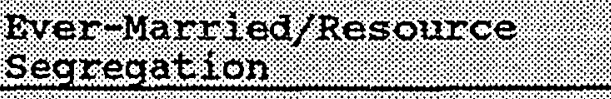 & 31.96 & \\
\hline 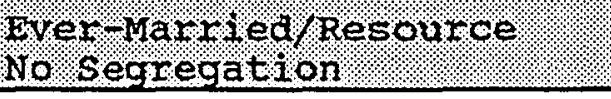 & $1,4.5$ & 30.51 \\
\hline $\begin{array}{l}\text { Ever-Married/No Resource } \\
\text { Segregation }\end{array}$ & 51.64 & \\
\hline $\begin{array}{l}\text { Ever-Married/No Resource } \\
\text { No Segregation }\end{array}$ & 3.25 & 48.39 \\
\hline
\end{tabular}

Table XXVII shows that the probability of an evermarried woman with a resource person to work at home is 
$31.96 \%$ if she has the segregation constraint compared to $1.45 \%$ for an ever-married woman with a resource person who does not have a segregation constraint. Hence, the impact of segregation for the ever-married woman with a resource person is 30.5 percentage points. In other words, an evermarried woman with a resource person is 30.5 percentage points more likely to work at home if she has a segregation barrier than the one who does not have a segregation barrier.

The probability of an ever-married woman without a resource person to work at home is $51.6 \%$ if she has the segregation constraint compared to $3.25 \%$ for an ever-married woman (without a resource person) who does not have a segregation constraint. Hence the impact of segregation for the ever-married woman without a resource person is 48.39 percentage points. That is to say, an ever-married woman without a resource person is 48.39 percentage points more likely to work at home if she has the segregation constraint than the one who does not have the segregation constraint. Therefore the impact of segregation at 48.4 percentage points is higher for the ever-married women with no resource than for the ever-married women with a resource at 30.5 percentage points. That is understandable since the women who are inclined towards segregation would have a higher probability of working at home if a resource person were 
available (thus highlighting the effect of the resource person)

The impact of segregation for the single woman is 52.4 percentage points while it is 48.4 percentage points for the ever-married woman. Hence the single woman is 52 percentage points more likely to work at home if she has the segregation constraint, while the ever-married woman is 48 percentage points more likely to work at home with the same constraint.

Overall, the model predictability, (including the cultural variables) as measured by the percentage of cases in the pooled sample predicted correctly, is $85 \%$. The reason other variables did not show significant relationships was probably due to collinearity. In fact, the simple correlation test showed significant correlation coefficients among the various demographic and socioeconomic variables: age and education; family size and income; child and resource; marital status and child; marital status and age; and marital status and education at the .001 significance level and between child and household income at the .01 level. Among the cultural variables, tradition and family objection had a significant correlation coefficient at the .01 level.

The simple correlation test showed interesting effects of age and education on the tradition variable. These results are in accordance with our hypotheses. The positive 
correlation coefficient between age and tradition (significant at the .001 level) indicates that the older women are more likely to have traditional attitudes than the younger women. The negative correlation coefficient between education and tradition indicates that the more educated the woman is, the less likely she is to have traditional attitudes.

Unfortunately, the small sample sizes ${ }^{7}$ associated with the "ever-married," and the "single" women samples limited the analysis to a one-stage approach for these two groups.

${ }^{7}$ Ever-married working women $(\mathrm{N}=88)$ : working at home $(n=60)$ / working outside the home $(n=19)$ Single working women $(\mathrm{N}=44)$ : working at home $(n=25)$ / working outside the home $(n=19)$ 
CHAPTER VI

SUMMARY AND CONCLUSIONS

This study looked into the factors that are believed to influence women's decisions regarding labor force participation. Traditionally, studies of female labor force participation tend to focus primarily on demographic and socio-economic variables. More recently, cultural variables have been included in female labor models to investigate their effect on women's labor force participation, especially in developing countries.

Since this study addresses women's work in poor communities, where women's activities occur in both the formal and the informal sectors with substantial economic activity taking place within the home, the study was carried out at two levels. The first looked at the factors that influence a woman's decision whether or not to participate in economic activity. Certain culture-related variables were formulated and tested. Only those that were statistically significant were included in the second level of analysis. The second level looked at the factors that determine whether a woman would work inside or outside the home. 
The analysis was carried out for a pooled sample that included all the women who are eligible for labor force participation in all marital categories. Separate analyses were then carried out for single, ever-married and currently-married women.

\section{FINDINGS}

In general, the findings support the hypotheses posed.

- Marital status was found to have a significant effect. As hypothesized, single women were more likely than ever-married women to participate in economic activity. Among the ever-married women, previously-married women were more likely to work than the currently-married women.

- Age also had a significant effect on women's work status. However, contrary to expectation, in the pooled sample, results showed that the older the woman the more likely she is to work. Nevertheless, for the married women, the result verified the hypothesis that the younger women are less likely to work than the older women.

- Household income was a significant variable. As expected, it had a negative effect on women's labor force participation for the pooled sample and the ever-married women's sample. However, it had no significant effect on single women's work status. 
- The presence of a resource person had a significant positive effect on women's labor force participation, as hypothesized.

- The number of preschool age children did not have an effect on women's labor force participation (due to collinearity with the resource variable). However, it had an effect (at the 10\% level of significance) on increasing the likelihood of women's work inside the home.

- Family size had a significant negative effect only in the currently-married women's sample. A larger family size decreased the likelihood of a currentlymarried woman from undertaking economic activity.

- Contrary to expectation, the husband's income did not have an effect on currently-married women's labor force participation.

- Education did not seem to have any effect on women's labor force participation in any of the marital categories. This situation could be reflecting the relatively low levels of education for these women in general. It could also be related to the fact that the majority of women (87\%) engage in informal sector-type activities, which do not require high levels of education. Hence, education is of no particular significance for women's work or the types of activity they actually undertake. However, in the 
model that included cultural variables, education had a significant effect in decreasing women's likelihood of working inside the home. Women with higher levels of education were more likely to be working outside the home.

- Moreover, for the total adult female sample population, the correlation between age and education showed a significant negative relationship (at the .001 level of significance. This indicates that younger women have higher education rates than older ones, the relevance of which is discussed under the policy implications section.

- Segregation was the only cultural variable that showed a significant relationship with a woman's choice of work inside the home. This was the case for women in all marital categories. As hypothesized, its effect was higher for the single than the ever-married women.

\section{POLICY IMPLICATIONS AND} RECOMMENDATIONS

The sample of women under investigation has shown that younger women have higher education rates than older ones. The inter-generational variation in educational attainment has profound implications as the young represent the potential future labor force. This may represent a shift in the types of occupations pursued, i.e. more towards formal 
than informal-type occupations. The expected resultant unemployment has consequences regarding employment creation at the national level; a pressing issue that governments of developing nations (as well as developed nations) have to persistently address.

The higher education rates of younger women may have positive effects at the household level. More educated women are expected to raise better children, the human asset that is the most important resource of a nation, especially a developing nation like Jordan that suffers from the lack of natural resources.

The change in education may, over time, also constitute a change in attitudes regarding women's place and roles. Add to it the continuously increasing economic pressures on households with limited resources. Although cultural barriers may not be expected to drop entirely and swiftly in the face of economic need, changes in attitudes are, nevertheless, expected due to rising expectations and aspirations to improve living conditions, the effects of which are worth investigating in micro socio-economic studies.

The causal and directional effects of the relationships between education, fertility and female labor force participation have not been deemed conclusive yet. However, there is strong evidence to support the assumption that with rising educational levels, women will have lower fertility 
rates over time (Caldwell, 1982; Curtin, 1982). Another assumption which this study finds worth highlighting is the intervening effect of female employment, supported by curtin (1982). Higher education will provide women with better chances for employment, which in turn will have a bearing on curtailing the fertility levels of working women, the effect of which will only be demonstrated over time. At the micro household level, the income of families with limited financial resources can have better distributional effects with a smaller rather than a larger number of children; this presumably should translate into a better quality of life. At the macro national level, governments with constrained budgets will have fewer subsidy outlays to support the poor and needy in the society. The savings in subsidy outlays can instead be allocated to macro level development ventures, like job expansion and versatility, and emphasis on improving regional and international trade relations. This case study also demonstrates the importance of interview design in revealing women's economic participation rates. While the Save the children (SCF) baseline survey yielded $9 q$ of the women as economically active, this study sample yielded a $30 \%$ participation rate. It could be argued that this difference represents the SCF income-generation intervention. This may partially be the case, but certainly not entirely. Firsthand knowledge of the Project and the 
community ${ }^{8}$ indicates that the vast majority of women who participated in the project are those who were already engaged in unorganized types of economic activity. Secondly, because the Project is governed by a market-driven strategy, there is always a bottleneck in regards to the numbers of participants the Project is willing to include, due to product quality and product turnover constraints. The importance of probing to capture and determine economic activity of women cannot be overemphasized. On the positive side, it reflects a productive capacity of the population higher than the figures shown by labor statistics. At the macro level of national development, acknowledging and enumerating women's activities in both the formal and the informal sectors, will add positively to the input of the female labor force into economic performance measures such as the Gross National Product and the Gross Domestic Product. For this purpose, similar studies need to be carried out at a national scale to depict women's contribution in the informal sector.

As a result, it is recommended that female labor force participation studies use comprehensive and exhaustive methods of probing during interviews, to determine the extent and magnitude of women's economic activity.

${ }^{8}$ The researcher worked in the Project for two years, between 1988 and 1989, and followed up on the progress of the Project to-date. The researcher was earlier involved in the design of the 1987 Baseline survey, the supervision of its implementation and analysis of the data set. 
Interviewers need to be made aware of the problems and shortcomings associated with the usually quick and superfluous conventional methods of data collection.

on this point, it is worth recommending and highlighting the importance of anthropological studies. Although this study did not use this methodology, the wealth of information provided by the women during the pre-test phase, points to the importance of such methods in enriching our understanding of certain factors. Intricate issues relating to women's Iife circumstances, their understanding and interpretation of motives and constraints, especially as they relate to cultural factors, can only be derived through such methodology. While the problems usually associated with anthropological studies are such that they are timeconsuming and not representative, they provide information and insight that the traditional one-shot surveys tend to overlook.

The number of women who were not working and who said they wished to work (24\% of the sample) has an important implication. This segment represents a potential labor force. If provided with employment opportunity, the female labor force rate in the communities goes up to $54 \%$ (from $30 \%$ who are actually working). It is important that the policy maker is made aware of the increasing numbers of women interested in employment. 
On one hand, the growing numbers of women seeking work relate to the issue of unemployment discussed earlier, and its implications for job creation and enhancement by the government. On the other hand, it has pertinent implications relating specifically to the issue of poverty. The fact that the presence of children does not necessarily impede poor women from pursing employment, albeit at home, may indicate the need of households for the woman's income. The need of poor women to work may indicate underlying deplorable conditions under which these households are living. Hence, women who see the need to work and contribute to family income, need to be supported in finding relevant work opportunities that are compatible with their life circumstances. The scope and extent of women's contribution to the income of poor households would probably have the effect of modifying development policies that are concerned with the alleviation of poverty and improving the well-being of poor households. Such policies may give priority to employment creation and enhancement programs. To support employment opportunity for women seeking employment would most certainly translate into improved livelihood of their family members. Therefore it is equally important that studies look into the whole context of women's life circumstances. Development policies concerned with quality life need to be aware that economic activities must be compatible with women's domestic and reproductive 
roles. The situation where a woman works outside the home and still has to carry out her domestic and child-care activities may indicate exploitation, especially in the case of poor women who may not be able to afford child-care services. Unless the situation is coupled with circumstances that are conducive and dignifying to women, then it is by no means an appropriate goal of development to only increase their already onerous burdens.

Policies that seek to increase female employment need to be sensitive to the cultural and demographic (fertilityrelated) considerations. Expanding the base of economic activities for women, provision of child care centers or the organization of reciprocal assistance arrangements within communities, are only a few examples of what could be done. Establishing child care facilities within communities will free mothers to work outside the home and will create child care jobs. Realizing that due to cultural barriers some women will still desire to only work at home, agencies (government and private) can be established to provide marketing channels for such economic activities at a national scale.

Another important policy recommendation is that more women be involved in professional and decision making arenas and in research relating to women's issues, since it is assumed that they are sensitive to the needs of their own gender. Women in policy and decision making levels may also 
help to modify current policies that are still insensitive to the constraints facing women in general and the plight of poor women in particular.

\section{FURTHER RESEARCH}

This study addressed women's demographic and socioeconomic conditions as they relate to their labor force participation in three low-income communities. When the sample of women was segregated by marital status to depict the effect of the various variables on women's labor force participation, it yielded small numbers for certain marital categories. Thus including the cultural variables in the single and ever-married women's separate models yielded insignificant results. Hence, it is recommended that similar studies be replicated with larger sample sizes. Longitudinal studies are also recommended. Where case studies investigate a certain (e.g. poverty-laden) area, longitudinal studies should prove useful in capturing change over time in regards to women's economic participation rates as well as changes in occupational distribution, wages, and other work-related conditions.

It is also recommended that studies of female labor force participation include culture-related variables. In this model, the cultural variable "segregation" showed a significant effect, while the others did not. These variables may have been redundant, and consequently the 
effect of one overshadowed the effect of the others. However, it is important that attempts be made to conceptualize and operationalize various cultural variables. This study investigated women's personal attitudes. Although these generally reflect those of her household members, it would be interesting to look into attitudes of husbands and other family members, such as parents. Understanding the effect of cultural and social attitudes on women's propensity to undertake economic activity, should provide leads to income-generating designs and employment enhancement programs in general. Therefore it is recommended that household-level studies leave room for interviewing other family members besides the female respondents.

Women's contribution to family income is assumed to have important consequences in regards to improving the living conditions of households in general, and poor households in particular. The effects of women's income on improving children's well-being have been amply substantiated in the literature. The awareness and recognition of women's contribution should have a positive effect on elevating their status at both the micro and macro levels. At the household level, women's elevated status could empower them in the sense of giving them more decision making roles and capacity. As women are considered the primary guardians of the future generation, improving their 
lot should benefit the whole society. Although the labor law of Jordan as well as many Arab countries give women equal rights and opportunities, at least theoretically, the actually low labor force participation rates of females indicate that women may in fact have been marginalized in the development process. Therefore, at the national policy level, recognizing women's contribution could put them on the development agenda with particular attention to their unique needs. 


\section{SELECTED BIBLIOGRAPHY}

Abu Nasr, J.; Khoury, N. F.; and Azzam, H. T., eds. 1985. Women, Employment and Development in the Arab World. Berlin: Mouton Publishers.

Acker, Joan. 1989. Doing Comparable Worth: Gender, Class, and Pay Equity. Philadelphia: Temple University Press.

Afshar, Haleh and Dennis, Carolyne, eds. 1992. Women, Recession and Adjustment in the Third World. New York: Saint Martin's Press.

al-Khayyat, Sana. 1990. Honour and Shame: Women in Modern Irag. London: Saqi Books.

Anker, R. and Knowles, J. 1978. "A Micro Analysis of Female Labour Force Participation in Kenya." Population and Labour Policies Program (Working Paper No. 116). Geneva: International Labor Office.

Anker, R. 1983. "Effect on Reported Levels of Female Labour Force Participation in Developing countries of Questionnaire Design, Sex of Interviewer and Sex/Proxy Status of Respondent: Description of a Methodological Field Experiment." Population and Labour Policies Program (Working Paper No. 137). Geneva: ILO.

Anker, R. 1984. Female Labor Force Participation in Developing Countries: A Critique of Current Definitions and Data collection Methods." International Labor Review, 122, No. 6, 709-725.

Anker, R. and Hein, C., eds. 1986. Sex Inequalities in Urban Employment in the Third World. London: Macmillan.

Archarya, M. and Bennett, I. 1982. "Women and the Subsistence Sector: Economic Participation in Household Decisionmaking in Nepal." Washington, D.C.: World Bank.

Assaf, Ghazi. 1979. The Size Distribution of Income in Jordan in 1973 (Draft Report). Amman: Royal Scientific Society, Economics Department. 
Athanassiou, S. 1982. "A Statistical Analysis of Female Participation in Work and Effects on the Population and Socioeconomic Development: A Case Study of Greece." In: A. Hoiberg, ed. Women and the World of Work. New York: Planum Press.

Azzam, H. 1978. "The Participation of Arab women in the Labor Force: Development Factors and Policies." Population and Labour Policies Program (Working Paper No. 80). Geneva: International Labor Office.

Barhoum, M. I. 1983. "Attitudes of University Students Toward Women's Work: The Case of Jordan." International Journal of Middle East Studies, 15, No. 3, 369-376.

Beck, Lois and Keddie, Nikki, eds. 1978. Women in the Muslim World. Cambridge: Harvard University Press.

Becker, G. 1965. "A Theory of Allocation of Time." Economic Journal, 75, No. 229, 493-517.

Belhachmi, Zakia. 1985. "Educating Women for Development: The Case of Morocco." IFDA Dossier (International Foundation for Development Alternatives, No. 47).

Beneria, L. and Sen, G. 1981. "Accumulation, Reproduction and Women's Role in Economic Development: Boserup Revisited." Signs, 7, No. 2, 279-97.

Berger, M. 1985. An Initial Assessment of the Women's Entrepreneurship Development Program. Washington, D.C.: International Center for Research on Women.

Bhatt, E. 1989. "Toward Empowerment." World Development, 17, No. 7, 1059-1065.

Black, Jan K. 1991. Development in Theory and Practice: Bridging the Gap. Boulder: Westview Press.

Blumberg, Rae Lesser. 1988. Income under Female vs. Male Control: Differential spending Patterns and the Consequences when Women Lose Control of Returns to Labor. Washington, D.C.: The World Bank.

Blumberg, Rae Lesser, ed. 1991. Gender, Family and the Economy: The Triple Overlap. Newbury Park: Sage Publications.

Bose, C. E. and Rossi, P. H. 1983. "Gender and Jobs: Prestige, Standings of occupations as Affected by Gender." American Sociological Review, 48, 316-330. 
Boserup, Ester. 1970. Women's Role in Economic Development. New york: st. Martin's Press.

Boserup, Ester. 1990. "Economic Change and the Roles of Women." In: Irene Tinker, ed. Persistent Inequalities. oxford, N.Y.: Oxford University Press.

Boulding, Elise. 1976. "Familial Constraints of Women's Work Roles." Signs: Journal of Women in Culture and Society, 1, No. 3, 95-117.

Bowen, W. and Finegan, T. A. 1969. The Economics of Labor Force Participation. Princeton: Princeton University Press.

Boydston, Jeanne. 1990. Home and Work: Housework, Wages, and the Ideology of Labor in the Early Republic. New York: Oxford University Press.

Bromley, Ray. 1978. "Introduction--The Urban Informal Sector: Why Is It Worth Discussing?" World Development, 6, No. 9/10, 1033-1039.

Bruce, J. and Dwyer, Daisy, eds. 1988. A Home Divided: Women and Income in the Third World. Stanford: Stanford University Press.

Bruce, J. and Lloyd, C. B. 1992, February 12-14. Beyond Female Headship: Family Research and Policy Issues for the 1990s. Paper presented at the International Food Policy Research Institute Workshop on Intrahousehold Resource Allocation: Policy Issues and Research Methods, Washington, D.C.

Buvinic, M. 1976. Women and World Development: An Annotated Bibliography. Washington, DC: Overseas Development Council.

Buvinic, M. 1984. Projects for women in the Third world: Explaining their Misbehavior. Washington, D.C.: International Center for Research on Women.

Buvinic, M. 1989. "Investing in Poor Women: The Psychology of Donor Support." World Development, 17, No. 7, 10451057 .

Buvinic, M. 1990. The Vulnerability of Women-Headed Household: Policy Questions and options for Latin American and the Caribbean. Washington, D.C. : International Center for Research on Women. 
Buvinic, M.; Lycette, A.; and McGreevey, W. P., eds. 1983. Poverty in the Third World. Baltimore: Johns Hopkins University.

Buvinic, M. and Rao Gupta, G. 1992, November 9-12. The Costs and Benefits of Targeting Poor Woman-Maintained Families in Developing Countries. Vienna: United Nations.

Buvinic, M.; Youssef, N.; and von Elm, B. 1978. WomenHeaded Households: The Ignored Factor in Development planning. Washington, D.C.: International Center for Research on Women.

Cain, G. G. 1966. Married Women in the Labor Force: An Economic Analysis. Chicago: University of Chicago Press.

Cain, M.: Khanam, S. R.; and Nahar, S. 1979. "Class, Patriarchy and Women's Work in Bangladesh." Population and Development Review, 5, No. 3, 405-438.

Caldwell, P. 1982. Population Change and Development in the ECWA Region (Cairo Demographic Center, Monograph Series No. 9). Cairo, Egypt.

Central Bank of Jordan. 1987. Monthly Statistical Bulletin. Amman, Jordan: Author.

Central Bank of Jordan. 1992. Monthly Statistical Bulletin. Amman, Jordan: Author.

Chamber of Industry. 1990. study of Small Industries in Jordan. Amman: Chamber of Industry.

Chekaibe, Natalie. 1990. "The Determinants of Female Labor Force Participation in Beirut." Unpublished Thesis, Beirut University College, Beirut, Lebanon.

Collier, Paul. 1989, February. Women and structural Adjustment. Paper presented to the Unit for the study of African Economies.

Collins, Jane L. and Gimines, Martha E., eds. 1990. Work Without Wages: Comparative studies of Domestic Labor and Self-Employment. Albany: State University of New York Press.

Concepcion, M. B. 1974. "Female Labor Force Participation and Fertility." International Labor Review, 109, No. 5-6, 503-517. 
Cornelius, D. 1988, April 22. Rising Women's Status and Persistent High Fertility: The Case of Jordan. Paper presented at the Annual Meeting of the Population Association of America, New Orleans.

Cornia, G. A.; Jolly, R.; and Stewart, F., eds. 1987. Adjustment with a Human Face. Oxford: Clarendon Press.

Curtin, L. 1982. Status of Women: A Comparative Analysis of Twenty Developing Countries. Washington, D.C.: Population Reference Bureau, Inc.

Davis, K. 1984. "Wives and work: the Sex Role Revolution and its Consequences." Population and Development Review, 10, No. 3, 397-417.

Deeb, Mary. 1988. The Impact of Family Formation Patterns on Childhood Mortality and Morbidity in Amman, Jordan. Ph.D. Dissertation, Johns Hopkins University.

Department of Statistics. 1964. Population and Housing Census, 1961, Vol. 2. Amman, Jordan: Author.

Department of Statistics 1976. Jordan National Household Survey, 1976. Amman, Jordan: Author.

Department of Statistics. 1979a. Jordan Fertility Survey, 1976, Vols. 1 and 2. Amman, Jordan: Author.

Department of Statistics. 1979b. National Census of the Population, 1979. Amman, Jordan: Author.

Department of statistics. 1980. Family Expenditure Survey, 1980. Amman, Jordan: Author.

Department of Statistics. 1984. Jordan Fertility and Family Health Survey, 1983. Amman, Jordan: Author.

Department of Statistics. 1986. Jordan Household Income and Expenditure Survey, 1983. Amman, Jordan: Author.

Department of statistics. 1987a. Health, Nutrition, Manpower, and Poverty Survey, 1987. Amman, Jordan: Author.

Department of Statistics. 1987b. Labor Force in Jordan: Analytical studies of the Manpower Survey 1982-1983. Amman, Jordan: Author.

Department of Statistics. 1992. Jordan Population and Family Health Survey, 1990. Amman, Jordan: Author. 
Dixon, Ruth. 1982. "Mobilizing Women for Rural Employment in South Asia: Issues of Class, Caste, and Patronage." Economic Development and Cultural Change, 8, 373-390.

Doan, R. and Popkin B. 1989. Women's Work and Care Arrangements in the Philippines. Paper presented at the Annual Meeting of the Population Association of America, Baltimore.

Durand, John D. 1975. The Labor Force in Economic Development. Princeton: Princeton University Press.

Easterlin, R. 1980. Birth and Fortune: the Impact of Numbers on Personal Welfare. New York: Basic Book Inc.

Economist Intelligence Unit (EIU) . 1980. Quarterly Economic Review of Jordan. London: EIU.

Economist Intelligence Unit (EIU) . 1989. Quarterly Economic Review of Jordan. London: EIU.

Elizaga, J. C. 1974. "The Participation of Women in the Labour Force of Latin America: Fertility and other Factors." International Labour Review, 109, No. 5-6, 519-538.

Elliott, c. 1975. Patterns of Poverty in the Third World. New York: Praeger Publishers.

El-Solh, C. F. 1985. "Migration and Selectivity of Change: Egyptian Peasant Women in Iraq." In: Nadia Hijab, ed. Womanpower: The Arab Debate on Women at Work. Great Britain: Cambridge University Press.

Elson, Diane, ed. 1991. Male Bias in the Development process. New York: Saint Martin's Press, Inc.

Engle, Patricia. 1980, August. The Intersecting Needs of Working women and their Young Children. New York: Report to the Ford Foundation.

Engle, P. 1991. "Maternal Work and Child-Care Strategies in Peri-Urban Guatemala." Child Development, 62, 954965.

Faroog, G. 1975. "Population, Manpower and Employment." In: $\mathbf{w}$. C. Robinson, ed. Population and Development Planning. New York: The Population Council.

Fernea, Elizabeth W., ed. 1985. Women and the Family in the Middle East: New Voices of Change. Austin: University of Texas Press. 
Folbre, Nancy. 1984. "Household Production in the Philippines: A Non-neoclassical Approach." Economic Development and Cultural Change, 32, No. 2, 303-330.

Folbre, Nancy. 1986. "Cleaning House: New Perspectives on Households and Economic Development." Journal of Development Economics, 22, No. 1.

Folbre, Nancy. 1991. "Women on Their Own: Global Patterns of Female Headship." In: Rita Gallin and Anne Ferguson, eds. The Women and International Development Annual (p. 2). Boulder: Westview Press.

Food and Agriculture Organization (FAO) . 1983, July 7-14. Time Allocation Survey: A Tool for Anthropologists, Economists and Nutritionists. Paper presented at Expert Consultation on Women in Food Production, Food Policy and Nutrition Division, Rome.

Gerner-Adams, D. J. 1979. "The Changing status of Islamic Women in the Arab World." Arab studies Quarterly, 1, No. 4 .

Grown, C. A. and Sebstad, J. 1989. "Introduction: Toward a Wider Perspective on Women's Employment." World Development, 17 No. 7, 937-952.

Gujarati, D. 1992. Essentials of Econometrics. New York: McGraw-Hill, Inc.

Hamermesh, D. S. and Rees, A. 1984. The Economics of Work and Pay, 3rd ed. New York: Harper and Raw Publishers, Inc.

Hammouda, A. 1985. "Participation and Integration of Jordanian Women in National Development 1975-84." In: Population and Development (Monograph Series No. 14) (pp. 3-7) . Cairo, Egypt: Cairo Demographic Center.

Hart, J. K. 1971, september. Informal Income opportunities and Urban Employment in Ghana. Paper presented at a conference on "Urban Unemployment in Africa" at the Institute of Development Studies, University of Sussex.

Hijab, Nadia. 1988. Womanpower: The Arab Debate on Women at Work. Great Britain: Cambridge University Press.

Hoodfar, Homa. 1990. "Survival strategies in Low Income Households in Cairo." Journal of South Asian and Middle Eastern Studies, 8, No. 4, 22-41. 
Ibrahim, Barbara. 1989. "Policies Affecting Women's Employment in the Formal Sector: Strategies for Change." World Development, 17, No. 7, 1097-1107.

International Labor organization. 1991. The Dilemma of the Informal Sector. Washington, D.C.: Author.

ISIS International. 1986. Women, struggles and Strategies: Third World Perspectives (Women's Journal No. 6). Rome: Author.

Jelin, Elizabeth. 1982. "Women in the Urban Labour Market." In: Anker et al., eds. Women's Roles and Population Trends in the Third World (pp. 239-267). London: Croom Helm.

Kandiyoti, Deniz. 1988. "Bargaining with Patriarchy." Gender and Society, 2, No. 3, 274-288.

Kawar, M. and Takriti, N. 1990. The status and Role of Women in Development in Jordan. Amman, Jordan: Ministry of Planning.

Killingsworth, M. R. 1983. Labor Supply. New York: Cambridge University Press.

Levine R. and Wong, R. 1989. "Household Structure in Urban Mexico: Accommodating Work and Child Care." Unpublished Paper presented at the meeting of the Population Association of America, Baltimore, MD.

Lewis, B. 1982. "Fertility and Employment: An Assessment of the Role Incompatibility Among African Urban Women." In: E. G. Bay, ed. Women and Work in Africa. Boulder: Westview Press.

Liedholm, Carl and Mead, Donald. 1987. Small Scale Industries in Developing Countries: Empirical Evidence and Policy Implications (MSU International Development Paper 9). East Lansing: Michigan State University, Department of Agricultural Economics.

Lipton, Michael. 1983. Labor and Poverty (World Bank St:aff Working Paper No. 616). Washington, D.C.: World Bank.

Lloyd, Cynthia B. and Brandon, Anastasia J. 1991. Women's Roles in Maintaining Households: Poverty and Gender Inequality in Ghana. Washington, D.C.: International Center for Research on Women. 
Lolo, Abdalla M. 1992. "Household Composition, Female Headship and Poverty in Egypt." Unpublished paper presented to the Population Council, Cairo, Egypt.

Macleod, Arlene E. 1992. "Hegemonic Relations and Gender Resistance: The New Veiling as Accommodating Protest in Cairo." Signs: Journal of Women in Culture and Development, 17, No. 2, 533-557.

Maguire, Patricia. 1984. Women in Development: An Alternative Analysis. Amherst: University of Massachusetts, Center for International Education.

Mernissi, F. 1976. "The Muslim World: Women Excluded from Development." In: I. Tinker and T. Bramsen, eds. Women and World Development. Washington, D.C.: Overseas Development Council.

Mernissi, Fatima. 1985. Beyond the Veil: Male-Female Dynamics in Muslim Society. London: Al Saqi Books.

Mernissi, Fatima. 1988. "Muslim Women and Fundamentalism." Middle East Report, July-August, 8-11.

Merrick, T. and Schmink, M. 1983. "Households Headed by Women and Urban Poverty in Brazil." In: M. Buvinic, M. A. Lycette, and W. P. McGreevey, eds. Women and Poverty in the Third World. Baltimore: Johns Hopkins University Press.

Mies, Maria. 1982. "The Lace Makers of Narsapur: Indian Housewives Produce for the World Market." In: Karen Sacks, A Two-Way street: Gendering International studies and Internationalizing Women's studies (Working Paper No. 24). Tucson: The University of Arizona, Southwest Institute for Research on women.

Mincer, J. 1962. "Labor Force Participation of Married Women." In: H. G. Lewis, ed. Aspects of Labor Economics (pp. 63-195). Princeton: Princeton University Press.

Ministry of Planning. 1976. Five Year Plan for Economic and Social Development 1976-1980. Amman, Jordan: Author.

Ministry of Planning. 1981. Five Year Plan for Economic and Social Development 1981-1985. Amman, Jordan: Author. 
Ministry of Planning. 1986. Five Year Plan for Economic and Social Development 1986-1990. Amman, Jordan: Author.

Ministry of Planning. 1993. Five Year Plan for Economic and Social Development 1993-1997. Amman, Jordan: Author.

Ministry of Social Development. 1987. Poverty Study. Amman, Jordan: Author.

Moghadam, Valentine M. 1992 . Development and Patriarchy: The Middle East and North Africa in Economic and Demographic Transition. Helsinki: United Nations University.

Molyneux, Maxine. 1979. "Beyond the Domestic Labour Debate." New Left Review, 116, 3-27.

Moser, Caroline. 1978. "Informal sector or Petty Commodity Production: Dualism or Dependence in Urban Development?" World Development, 6, No. 9/10, 1041-1064.

Moser, Caroline. 1989. "Gender Planning in the Third World: Meeting Practical and Strategic Gender Needs." World Development, 17, No. 11, 1799-1826.

Mujahid, G. B. 1985. "Female Labor Force Participation in Jordan." In: J. Abu Nasr, N. Khoury, and H. Azzam, eds. Women, Employment and Development in the Arab World. Berlin: Mouton Publishers.

Municipality of Amman. 1979. Urban Development Project: Feasibility Study. Amman, Jordan: Author.

Municipality of Amman. 1993. Technical Report: Development of the Less-Developed Communities in Greater Amman. Amman, Jordan: Author.

Nassif, Hind. 1976, October. Women's Economic Roles in Developing Tunisia. Paper presented at the AAUG Committee on Arab women's Development, New York.

Nawar, L. and Nizamuddin, M. 1986. "Women, Population and Development." In: Population and Development (Monograph Series No. 14). Cairo: Cairo Demographic Center (CDC).

Oppenheimer, V. K. 1982. Work and the Family: A Study in Social Demography. New York: Academic Press, Inc. 
Papps, Ivy. 1992. "Women, Work and Well-Being in the Middle East: An Outline of the Relevant Literature." Journal of Development Studies, 28, No. 4, 595-615.

Peek, Peter. 1978. "Family Composition and Married Female Employment: The Case of Chile." In: Guy Standing and Glen Sheehan, eds. Labour Force Participation in LowIncome Countries. Geneva: IIO.

Rao, Aruna: Anderson, Mary B.; and Overholt, Catherine A., eds. 1991. Gender Analysis in Development Planning: A Case Book. West Hartford: Kumarian Press.

Rasevic, Miroslav. 1978. "The Determinants of Labour Force Participation in Yugoslavia." In: Guy standing and Glen Sheehan, eds. Labour Force Participation in LowIncome countries. Geneva: ILo.

Rihani, May. 1977. Development as if Women Mattered: An Annotated Bibliography with a Third World Focus (Occasional Paper No. 10). New York: New Trans-Century Foundation.

Rockwell, Susan. 1985. "Palestinian Women and Work in the West Bank and Gaza." Journal of Palestine Studies, 14, No. 2, Issue 54 .

Rogers, Barbara. 1980. The Domestication of Women: Discrimination in Developing Societies. London: Kogan Page.

Rogers, Beatrice. 1991. Female Headship in the Dominican Republic: Alternative Definitions and Implications for Food Consumption and Nutrition. Medford: Tufts University School of Nutrition.

Rosenhouse, Sandra. 1988. Identifying the Poor: Is Headship a Useful Concept? (Working Paper No. 58). Washington, D.C.: World Bank.

Save the Children Foundation (SCF). 1987. A Baseline Socio-Economic and Health Survey. Jordan: Author.

Schultz, T. P. 1978. "The Influence of Fertility on Labor Supply of Married Women: Simultaneous Equation Estimates." Research in Labor Economics, 2, 273-351.

Schultz, T. Paul. 1989. "Women's Changing Participation in the Labor Force, A World Perspective." Policy. Planning, and Research Working Papers: Women in Development. Washington, D.C.: The World Bank. 
Secombe, I. J. 1984. Jordan, World Bibliographical Series, Vol. 55. Oxford, England: CLIO Press.

Shaaban, Radwan Ali. 1988. Inequality in Jordan: Income Distribution and its Social Impact in Jordan, 1980-1986. Amman, Jordan: Ministry of Social Development.

Shakhatreh, Hussein I. 1990. "The Determinants of Female Labor Force Participation in Jordan." Unpublished Dissertation, University of Michigan.

Share', Monther. 1988. Income Distribution: Education as a Determining Factor. Paper presented for the workshop "Income Distribution and its Social Impact in Jordan," Amman, Jordan.

Sheehan, G. 1978. "Labor Force Participation Rates in Khartoum." In: G. Standing and G. Sheehan, eds. Labor force Participation in Low-Income countries. Geneva, ILO.

Shorter, Frederic and Zurayk, Huda. 1985. Population Factors in Development Planning in the Middle East. New York: The Population Council.

Simmons, G. 1986. "Theories of Fertility." In: G. Farooq and G. Simmons, eds. Fertility in Developing Countries: An Economic Perspective on Research and Policy Issues. London: McMillan Press.

Smith, J. P., ed. 1980. Female Labor Supply: Theory and Estimation. Princeton: Princeton University Press.

Smock, A. C. and Youssef, N. H. 1977. "Egypt from Seclusion to Limited Participation." In: J. Z. Giele and A. C. Smock, eds. Women: roles and status in Eight Countries (pp. 33-79). USA: Wiley-Interscience Publications.

Standing, G. 1976. Concepts of Labor Force Participation and Underutilization (Working Paper No. 40). Geneva: ILO.

Standing, G. 1978. "Female Labour Supply in an Urbanizing Economy." In: Guy standing and Glen Sheehan, eds. Labour Force Participation in Low-Income countries. Geneva: ILO.

Standing, G. 1978. Labor Force Participation in Low Income Countries. Geneva: ILO. 
Standing, Guy. 1989. "Global Feminization through Flexible Labor." World Development, 17, No. 7, 1077-1095.

Steel W. F. and Campbell, C. 1982. "Women's Employment and Development: A Conceptual Framework Applied to Ghana." In: E. G. Bay, ed. Women and Work in Africa. Boulder: Westview Press.

Stokes, C. S. and Hsieh, Y. S. 1983. "Female Employment and Reproduction Behavior in Taiwan." Demography, 20, No. $3,313-331$.

Stone, Karen. 1983. "Motherhood and Waged Work: West Indian, Asian and Whilte Mothers Compared." In: A. Phizack Lea, ed. One-Way Ticket: Migration and Female Labour (pp. 33-52). London: Routledge and Kegan Paul.

Stycos, J. and Weller, R. 1967. "Female Working Roles and Fertility." Demography, 4, 210-217.

Sweet, J. 1973. Women in the Labor Force. New York: Seminar Press.

Tanfer, Koray. 1975. "Working Women: A Study of Female Labor Force and Determinants of Participation in Six Large Cities of Turkey, 1970." Dissertation in Demography, University of Pennsylvania.

Tovo, M. 1984. "The Determinants of Female Labor Force Participation." Unpublished Dissertation, Vanderbilt University, Nashvilie.

Tutunji, R. 1978. A Report of the status of women in Jordan. Amman, Jordan: USAID.

United Nations. 1976. Report of World Conference of the International Women's Year, 1975. New York: Author.

United Nations. 1985. Women's Employment and Fertility: A Comparative Analysis of World Fertility Survey Results for 38 Developing Countries (No. 96). New York: UN Population studies.

United Nations Children's Fund (UNICEF). 1991. Jordan 1991 Annual Report: Protecting Children in Time of crisis. Amman: Author.

United Nations Educational, Scientific and Cultural Organization (UNESCO). 1983. Bibliographic Guide to Studies on the status of Women: Development and Population Trends. New York: Author. 
United Nations Fund for Population Activities (UNFPA) . 1979. Report of Mission on Needs Assessment for Population Activities (Report No. 18). New York: Author.

Uthoff, A. and Pernia, E. M. 1986. An Introduction to Human Resources planning in Developing Countries (Background Paper No. 2). Geneva: ILO.

Van Ginneken, W. 1988. "Employment and Labour Incomes: A Cross-Country Analysis (1971-1986)." In: W. Van Ginneken, ed. Trends in Employment and Labour Incomes: Case studies on Developing Countries. Geneva: ILO.

Varma, M. 1985. The Dual oppression: To Be Poor and Also a Women (Working Paper Series No. 5). New Brunswick: Rutgers University.

Williams, Linda B. 1990. Demography, and Family DecisionMaking: The staus of Women in Rural Java. Westview Press.

World Bank. 1990. World Development Report: Poverty. New York: Oxford University Press.

Yehia, M. A. 1977. "Women and Development, Research Trends in the Arab Middle East and North Africa." In: May Rihani, ed. Development as if Women Mattered: An Annotated Bibliography with a Third World Focus (Occasional Paper No. 10). New Trans-Century Foundation.

Youssef, N. H. 1974. Women and Work in Developing Societies. Berkeley: Institute of International Studies, University of California.

Youssef, N. H. 1976. "Women in Development: Urban Life and Labor." In: I. Tinker, ed. Women and World Development (pp. 70-77). New York: Overseas Development Council.

Youssef, N. H. 1982. "The Interrelationship Between the Division of Labor in the Household, Women's Roles and Their Impact on Fertility." In: R. Anker, M. Buvinic, and $\mathrm{N}$. Youssef, eds. Women's Roles and Population Trends in the Third world. London: croom Helm Ltd.

Youssef, N. H. and Hetler, Carol. 1983. Rural Households Headed by Women: A Priority Issue for Policy Concern. Geneva: ILO. 
Zurayk, Huda. 1979. "The Changing Role of Arab Women." Population Bulletin of The United Nations, Economic Commission for Western Asia (No. 17) . Washington, D.C.: United Nations. 
APPENDIX A

JORDAN: A COUNTRY PROFILE 


\section{JORDAN}

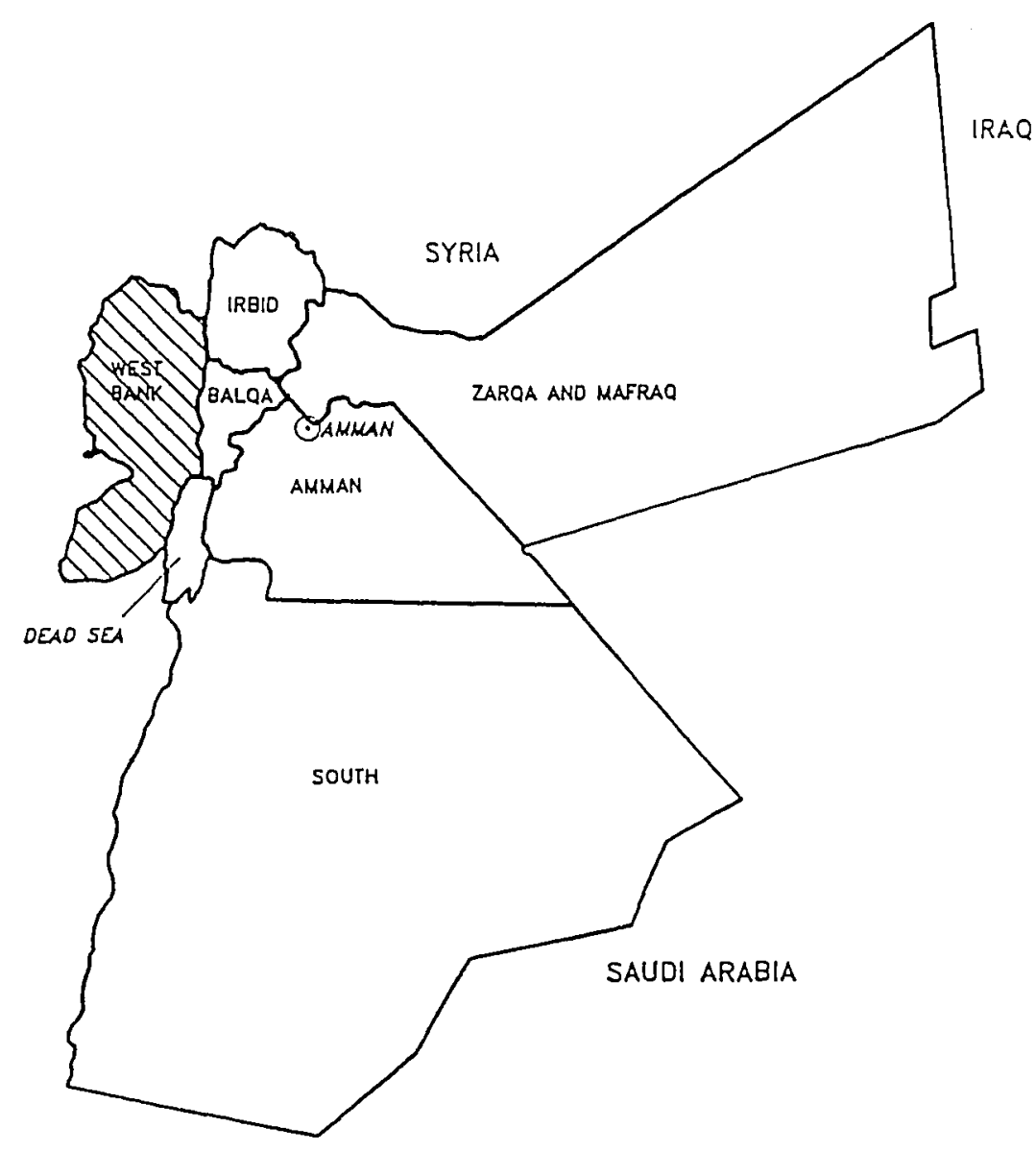




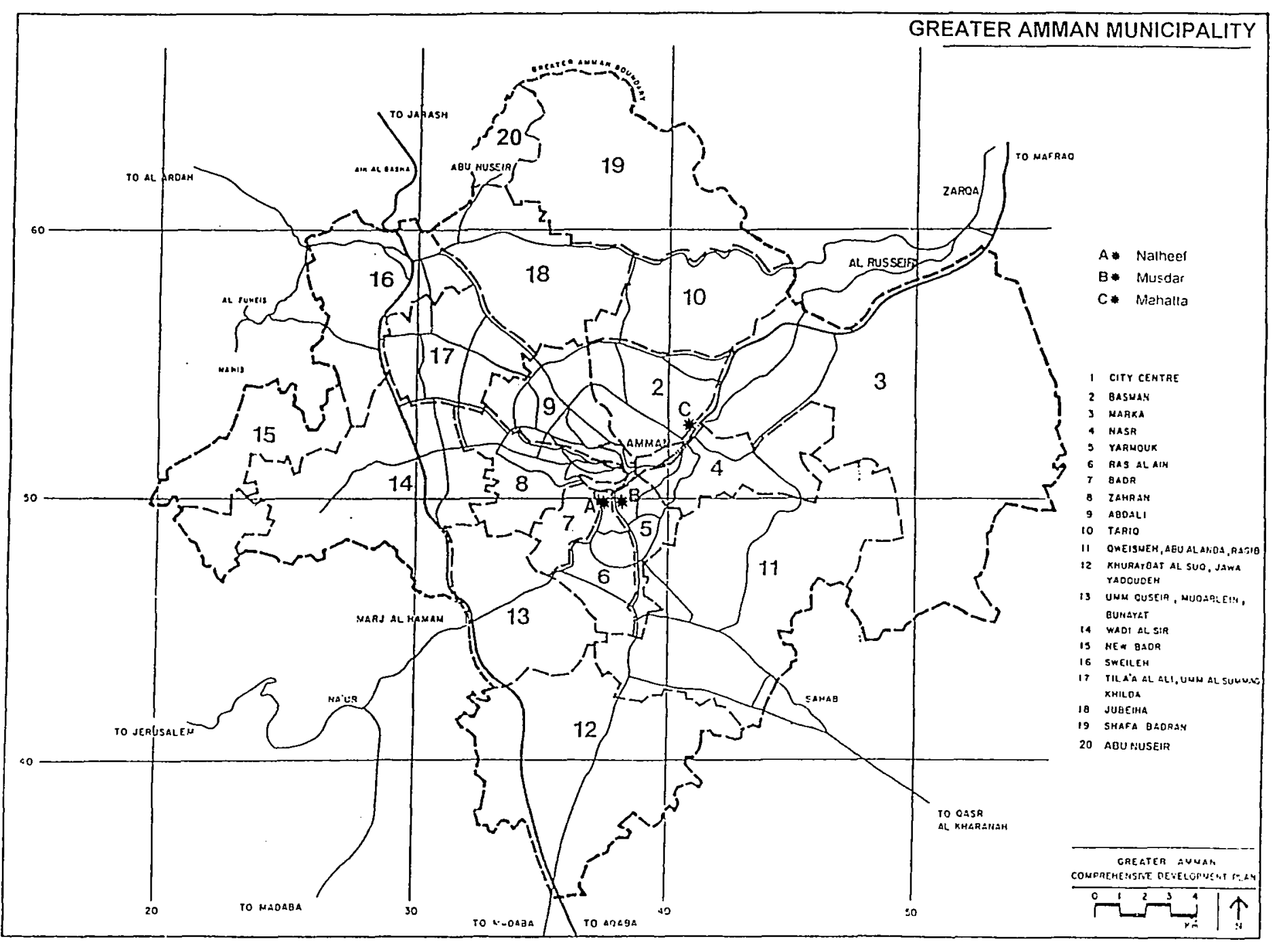


JORDAN

\begin{abstract}
History
Jordan was part of the ottoman Empire until 1921 when it gained its independence. It was declared a political entity known as "Trans-Jordan" in 1923. As a result of the establishment of the state of Israel in 1948, Trans-Jordan and the West Bank were united in 1950, and assumed the current name of the Hashemite Kingdom of Jordan. In 1967, the West Bank and Gaza Strip were occupied by Israeli forces, causing a massive influx of migrants to the East Bank. The West Bank was excluded from the Kingdom in 1988 upon the desire of the Arab states to facilitate the establishment of the Palestinian state (Department of statistics, 1992).
\end{abstract}

\title{
Social structure
}

Jordan has a fairly homogeneous population whereby $98 \%$ are Arab. The remaining ethnic minorities are circassian, Shishan and Armenian. Ninety-five percent of the population are Sunni Muslim, while the rest are mostly Christian (Department of Statistics, 1992).

Although ethnic and linguistic minorities are numerically insignificant, they are represented in the political leadership. A proportionate number of Christians and Circassians (Sunni Muslims who came to Trans-Jordan in the 1870s) are elected to the Lower House of Parliament, and one Circassian and two Christian Arabs are usually appointed to the cabinet.

Jordan's Constitution recognizes Islam as the country's official religion, and the Islamic-Arab culture dominates the country. Arabic is the official language of the country and is spoken by all the population. English is also fairly widely spoken.

\section{Geographic Distribution and Urbanization}

Jordan is located on the traditional and primary route between the Mideast oil-producing countries and the Mediterranean sea. It is almost entirely land-locked. The port of Aqaba in the far south is Jordan's only outlet to the sea. The topography provides many contrasting features within a relatively small area $(36,715$ square miles, approximately the size of Indiana). There are three major distinguishable regions. The highlands region of the north 
and northeast is mountainous and rocky. The eastern and southeastern steppes and desert land comprise about $80 \%$ of the total land area. The western region encompasses the lowest spot on earth. The Dead sea occupies the central portion of the rift that forms the Jordan Dead Sea--Wadi Araba valley between two blocks of highlands.

The country is divided into eight governorates, which are organized in three regions: Irbid and Mafraq in the Northern region; Amman, Zarqa, and Balqa in the central region; and Karak, Tafielah, and Ma'an in the Southern region. The major cities are Amman, Zarqa, and Irbid (Department of Statistics, 1992) (See map).

The population of Jordan is unevenly distributed and is cuncentrated in the north and west. More than $96 \%$ of the population lives on about $24 \%$ of the land. The rest of the country is sparsely populated. The uneven distribution of the population is attributable to several factors such as climate, productivity of the land, urbanization and provision of infrastructure services.

Jordan has a high percentage of urban population. More than $70 \%$ of the population live in localities of more than 5,000 inhabitants. These localities are concentrated in the three largest, most urban governorates, Amman, Zarqa and Irbid, which are named after the three largest cities. Twenty-five percent of the population live in the capital, Amman; while Zarqa and Irbid cities are inhabited by more than 10 and $5 \%$ of the country's population, respectively (Department of Statistics, 1992). Amman, the capital, is the seat of economic, trade, educational and industrial institutions as well as the center of administration, politics and finance.

\section{Population and Demographic Conditions}

Prior to 1952, there was no organized attempt to study the population of the East Bank of Jordan, except for rough estimates based on registers compiled by the United Nations Relief and Welfare Agency (UNRWA). The 1952 Housing Census, which was conducted with limited data, estimated the population of the East Bank at 586,000. Two complete censuses were conducted in 1961 and 1979 showing the population at 901,000 and 2.13 million respectively. Thus the annual growth during the two-census period was $4.8 \%$. By 1990 the population had increased to 3.45 million (National Population Commission, 1991), hence the average increase between 1979 and 1990 was $4.3 \%$ annually. At this rate, the population can be expected to double in 16 years (Department of statistics, 1992). 
The most serious problem facing the government after the 1991 Gulf War was the return of large numbers of Jordanian nationals who had been working in the Gulf countries. By the end of 1990, their number was estimated to reach 300,000 , most of whom came from Kuwait (Department of Statistics, 1992). The sudden increase in the population created problems of unemployment and poverty, and a general worsening of the standard of living. A socio-economic profile of the returnee families carried out by UNICEF (United Nations Children's Fund) in December 1990, found that $44 \%$ were under the age of $15,83 \%$ of the returnee labor force was unemployed, and $33 \%$ were below the poverty line.

Results of the Health, Nutrition, Manpower, and Poverty Survey conducted in 1987 (Department of statistics, 1987) indicate that the age structure of the population has changed considerably since 1979, primarily as a result of changes in fertility, mortality, and migration. The proportion of population under 15 years of age declined from $57 \%$ in 1979 to $46 \%$ in 1987, while the proportion age 65 or over increased from $2.8 \%$ in 1979 to $3 q$ in 1987.

\section{Fertility}

Jordan's population is characterized by a high level of fertility. Jordan does not have an official population policy to curb the high fertility rate. In 1979 , the United Nations Fund for Population Activities (UNFPA) observed that the people of Jordan seem to continue to adhere to traditional norms that favor a large family size (UNFPA, 1979). Due to their awareness of the interrelationship between population growth and development, Jordanian planners are concerned with excessive population growth undermining development efforts.

However, fertility has been declining. Recent fertility surveys indicated a decline in female total fertility from 8.8 children per woman in 1961 to 7.7 and 6.2 in 1976 and 1985 respectively. The estimated crude birth rate, based on births registered with the Department of Civil status and Passports, was 50 births per thousand population in the early 1970s. This declined to 34 births per thousand population in 1990 (Department of statistics, 1992).

\section{Mortality}

Mortality has been declining even faster than fertility. The crude death rate, estimated at 19 deaths per thousand population in the 1950s, had declined to 12 per thousand two decades later. In 1990, the crude death rate was estimated 
to be 7 deaths per thousand population (Department of statistics, 1992). Another measure of mortality, the infant mortality rate, was estimated at 125 deaths per thousand live births for the period 1950-1955. After twenty years, it had declined by half to 67 per thousand, and in 1980-1987 it was estimated to be 49 deaths per thousand live births. Thus, with the continuation of a declining death rate, the gap between the birth and death rates has been widening.

\section{Internal and International Migration}

According to the 1986 Internal Migration Survey (Department of Statistics, 1986) $6 \%$ of the population are lifetime migrants and 98 are current migrants. Lifetime migrants are calculated based on place of birth, while current migrants are calculated based on the last place of residence. The study was limited to the East Bank, with the governorates as geographic units. Forced migration from the West Bank and Gaza strip was not included.

Internal migration has generally taken place over short distances and occurs mainly in the central region. The movement of people from rural to urban areas is an important factor in the rapidly increasing population density in urban areas.

International migration in Jordan flows in two directions. There has always been considerable population movement from Jordan to the Gulf states. At the same time, migrants are coming into Jordan from Egypt, Syria, and Asia, mainly sri Lanka and the Philippines.

\section{Household Composition}

Large households are common in Jordan. The average number of members in a household is nearly 7. Thirty-two percent of households are comprised of 9 or more persons. The figure is higher (39\%) in rural areas, and lower (25\%) in large cities. The majority of household in Jordan (71\%) are nuclear families, comprised of parents and children (Department of Statistics, 1992).

Comparison of the data from the 1990 Jordan Population and Family Health Survey with data from previous surveys regarding the proportion of ever-married women, indicates that the percentage of women in the population who are married is decreasing gradually in almost all age groups. Among women in the 15-19 age group, for example, more than 308 were married according to the 1972 National Fertility Survey (Department of statistics, 1976). This percentage 
declined to $20 \%$ in 1976, $13 \%$ in 1983, and $11 \%$ in 1990. By age 30 , when almost all women would have been married, the percentage was 96 in 1972, 90 in 1983, and 89 in 1990 .

\section{Education}

Basic education is free and compulsory, starting at age six and lasting for 10 years. A further two-year period, known as the secondary cycle, is virtually free. It is worth noting here that although education is compulsory, there is no system of enforcement.

The percentage of basic school attendants (within the school-attending age group) rose from $87.8 \%$ in 1979 to $94.2 \%$ in 1991, while the percentage of secondary school attendants dropped from $72 \%$ to $65.8 \%$ for the same years (Department of Statistics, 1992).

The figures for median number of years of schooling indicate that public education has a long history in Jordan. Men age 50-54 have a median of 6 years of education (equivalent to completing primary school), while women in the same age cohort have less than one year. Among persons age 35-39 years, the median duration of schooling for men is close to 10 years, whereas women have a little more than 6 years. For persons 25-34 the gap narrows, and finally disappears for those under 25 years of age (Department of statistics, 1992).

The level of education of women is associated with different levels of fertility in Jordan. The results of the 1976 Jordan Fertility survey (Department of Statistics, 1976) showed an inverse relationship between the level of education and fertility. The total fertility rate declined from 9.0 for women with no schooling to 6.1 and 3.2 for women with primary education and secondary education respectively.

Health

The national health policy is based on the principle that all citizens have the right to health services. The objective of the government is to achieve "Health for all by the year 2000," in accordance with the guidelines set forth by the World Health Organization.

The health sector has witnessed significant progress. Not only have death and infant mortality rates declined, as mentioned earlier, but life expectancy at birth increased from 46.1 years in 1961 to 69 years in 1984. The number of 
health centers expanded from 89 in 1981 to 150 and 197 in 1984 and 1986, respectively.

Socio-Economic Development

The development process in Jordan moved from planning for single projects in the 1950s to comprehensive economic programs in the 1960s. The 1970 s and 1980 s witnessed the emergence of socio-economic plans at a national level.

During the 1952-1966 period, prior to the Israeli occupation of the West bank, the Jordanian economy achieved substantial growth in spite of its limited natural resources. It succeeded in setting up basic infrastructure, establishing a number of industries and implementing irrigation and agricultural projects. Educational and health services were also developed, and the institutional and administrative framework for development was upgraded.

The period 1967-1973 was characterized by economic recession resulting from regional political and security

considerations. The occupation of the West Bank in 1967 deprived Jordan of an important part of its natural and economic resources, adversely affecting its development and diverting resources to military expenditure and armament. Forced emigration from the occupied territories to the East Bank led to demographic imbalances and a sudden rise in the population, with resultant unemployment and pressures on public spending to accommodate the displaced. At the same time, deteriorating security led to a decline in investment expenditures by the public and private sectors.

In 1972, economic activities began to recover from the setbacks of the 1967-1971 period. The government recommended systematic socio-economic development. A Three-Year Development Plan (1973-1975) was drawn up and concentrated on reactivating the economy and enhancing employment opportunities. The Gross Domestic Product (GDP) at factor cost grew by $5.9 \%$ annually in real terms during this plan period (Ministry of Planning, Jordan, 1986).

Due to the successful performance of the economy in the 1973-1974 period, the first Five-Year Plan (1976-1980) was formulated in light of a set of new factors. There was a large increase in Arab assistance and loans to Jordan as a result of the oil boom in the Arabian Gulf, and growing demand for Jordanian manpower in the Gulf countries.

There was an increase in migration to the cities, a rise in the natural population growth rate, and an out-migration of Jordanians to the Gulf states for employment purposes. 
While there was a significant rise in the value of remittances by Jordanian workers abroad, there was a parallel shortage of skills within Jordan, leading to the import of $\mathrm{Arab}$ and foreign labor. Other factors that affected the economy were higher oil prices, inflation, general wage and salary increases and a rise in government subsidies on staple foods and fuel.

During this period Jordan enjoyed favorable economic and social conditions, facilitating high growth in both GDP and GNP and a concomitant expansion of the economy's productive base. The economy achieved a real annual growth rate of GDP at factor cost of 12.18 during 1976-1980. However, in light of a relatively non-restrictive imports policy, there was an increase in the volume of commodity imports to meet rising consumption on the one hand and a growing demand for capital and intermediate goods and raw materials required for investment on the other. As a result, as well as because the rise in exports did not keep pace with imports, the balance of trade deficit increased. Nevertheless, the surplus realized in the services balance and in unrequited transfers was instrumental in offsetting the deficit.

The second Five-Year Plan (1981-1985) was formulated in an atmosphere of optimism. The Plan assumed a continuation of existing positive trends, such as the inflow of Arab and international aid and a favorable development of trade relations. The civil war that started in Lebanon in 1975 added some stimulus to the economy since investment capital was channeled to Amman, which began to replace Beirut as the regional services center (Secombe, 1984). Also the start of the Iraq-Iran war in 1980 increased the demand for goods and transit routes via Jordan in lieu of the ports along the Arabian Gulf that were blocked by the war (Economist Intelligence Unit, 1980).

Yet, signs of economic recession reappeared in the mid 1980 s as a result of diminishing oil returns and the negative impact on overall economic activities in the region, which decreased domestic and external demand for Jordan. The decline of oil prices led to the suspension of Arab aid payments pledged to Jordan at the 1978 Baghdad Arab Summit meeting. Jordan's economy witnessed increasing public sector cash flow problems. This new condition forced the government to postpone many of its development projects and cut down government spending and capital expenditures. The government also imposed regulations regarding the importation of luxury goods such as cars and other appliances, to reduce the balance of trade deficit. consequently, there was a sharp increase in the prices of many goods. Actual economic performance fell below the Plan's projections. The GDP at factor cost grew at an 
annual real rate of only $4.2 \%$ during the 1981-1985 period compared with $11.2 \%$ envisaged by the Plan.

As a result of the delay in addressing the imbalance that appeared in the early 1980s, the Jordanian economy witnessed a severe economic crisis during the second half of the eighties. This crisis was manifest in average GDP growth rates that were lower than the population growth rate, resulting in a decrease in the standard of living index, increased unemployment, larger budget deficit, and an increased foreign debt. International and regional economic and political changes led to severely eroding sources of foreign financing, dictating the need to invest and export. Also the Gulf Crisis in 1990 led to the erosion of the export markets in Kuwait and Iraq, in addition to severely affecting remittances from Jordanians working in the Gulf states, mainly Kuwait.

There was a need to enhance the stability of economic activity free from severe fluctuations in economic performance rates. There also was the need to realize greater equilibrium in Jordan's balance of payments, through strengthening industrial linkages, increasing production of intermediate goods and developing local production of capital goods to generate a larger demand for internal investment opportunities, to help curb the flow of funds. As a result, the 1989-1993 Economic Reform Program was adopted to address the basic imbalances in the government budget and the balance of payments, and to maintain an acceptable rate of growth.

The Economic Reform Program was addressed in three portfolios, infrastructure, investment and the social services. The social services portfolio includes the health, education and housing sectors. The infrastructure portfolio includes energy and mineral resources, water and irrigation, communications, construction and transportation. These sectors contributed $27.6 \%$ of GDP on average between 1986 and 1992 , and absorbed $21.5 \%$ of the labor force in 1991 (Ministry of Planning, 1993). Sectors in this portfolio enjoy a large rate of capital formation as a result of heavy government investments in them.

Jordan has phosphate and potash as the two major mineral extractive industries. The production of phosphate, the country's leading industry, reached $6.3 \mathrm{million}$ tons in 1986, and its export value amounted to J.D. 64.8 million, reaching $29 \%$ of total exports (Central Bank of Jordan, 1987). The Economist Intelligence Unit (1989) ranked Jordan as the world's third largest exporter of phosphate. Potash, the second largest mining industry, increased production from 282 thousand tons, at its onset in 1983, to 1.1 million 
tons in 1986. Its export value amounted to J.D. 31.4 million in 1986.

other considerable industries in Jordan are the fertilizer manufacturing, petroleum products processing, cement, glass and pharmaceuticals. These industries were established with consideration of the markets of the neighboring Arab countries to make up for the small domestic market and to benefit from the economies of scale. However, this condition rendered these industries vulnerable to the regional recession that took place in the mid 1980 s.

The sectors comprising the investment portfolio are agriculture, mining, manufacturing industries, commerce and tourism. They contributed to $34.6 \%$ on the average of GDP at cost during 1986-1992.

The trade and tourism sectors contributed at a higher rate than the other sectors during 1986-1988, while the transformation (manufacturing) industries sector played a major role from 1989 to 1992. This was due, mainly, to the devaluation of the Jordanian currency in 1988, thus increasing the ability of Jordanian products to compete internationally. It was also due to the return after the Gulf War of many expatriates from the Gulf region who invested their savings in the industrial sector. Investment in this sector reached $33.8 \%$ of the total portfolio in 1992, and the number of jobs in this sector doubled between 1986 and 1992 .

The trade and tourism sectors employ the largest percentage of the workiorce, and the relative importance of these sectors as employers increased from $10 \%$ in 1986 to $16.3 \%$ in 1992 .

The agricultural sector, characterized by its forward and backward linkages with the industrial and services sectors, contributed $7.7 \%$ of GDP and absorbed $7 \%$ of the workforce in 1991. Agricultural exports represented $11 \%$ of overall exports, but imports of agricultural products were four times as large as exports.

The agricultural sector in Jordan faces several constraints that hamper its progress. The scarcity of water necessitates irrigation of about $7 \%$ of the cultivated land. Irregularity of rainfall and the lack of arable land limit agricultural output and lead to a gap in the food consumption requirements. Hence, the imports of food reached J.D. 155.7 million in 1987 (Economist Intelligence Unit 1989). 
The importance of the industrial sector increased substantially in the past few years, and its contribution to GDP at 1985 prices increased from $11.3 \%$ in 1986 to $13.1 \%$ in 1992. It absorbed $8 \%$ of the workforce in 1991. Again, imports of industrial products represented more than four times the value of exported products between 1987 and 1991 . The mining sector's contribution to GDP in 1992 reached $3.1 \%$, compared to $4.1 \%$ in 1986 .

Despite the expected continuation of an unfavorable trade balance, a long term plan (1993-1997) was drawn and designed to eliminate the goods and services account deficit so that the balance of trade deficit would be offset by the services account surplus. To this end, emphasis was placed on the increase, diversification and development of domestic production in order to meet a larger portion of local demand, reduce the percentage of imported goods and non-factor services to GDP at both market and constant prices and to contribute to the development of export-oriented production to respond further to the demand of neighboring markets. However, the Gulf Crisis has deprived Jordan, at least up to this date, of the regional markets its economy depended on.

\section{The Jordanian Labor Force}

The size, growth and structure of the Jordanian labor force have been influenced by many demographic, economic and social factors. Because of a high fertility level, Jordan has a very young population. As a result, it has a low crude labor force participation rate (total labor force / total population). In 1982 the crude labor force participation rate was $20 \%$ (Department of Statistics, 1984). In- and out-migration also influenced the size and structure of the labor force. In 1987, the number of Jordanian workers in the Gulf states was estimated to be 325,000 and the in-migration of foreign labor was estimated at 180,000 (EIU, 1989). Consequently, the crude labor force participation rate declined from $24 \%$ in 1961 to about $20 \%$ in 1983. This decline was accompanied by an increase in female labor force participation from $3.1 \%$ in 1961 to 7.7 and $8.4 \%$ in 1979 and 1983 respectively (Department of Statistics, 1984).

The total labor force in Jordan grew from 218,000 in 1961 to 446,000 in 1979 and 920,000 in 1991. In 1991 the refined labor force rate (workforce / working-age population, age 15-64 years) was 41.3\%. The labor force (the population in working age, 15-64 years) has increased from 45\% in 1979 to $54 \%$ in 1991 (Ministry of Planning, 1993). 
As a result of return migration and recession at home, unemployment has been rising rapidly. It rose from $14.8 \%$ in 1987 to 17.18 in 1991. Unemployment rate among the female labor force, however, was $34.2 \%$ compared to $14.5 \%$ among the male labor force (Ministry of Planning, 1993).

Unemployment rates varied widely between 1961 and 1988 (Chart A-1). The 1961 census showed the unemployment rate to be $7.1 \%$. It then rose to about $14 \%$ in 1970 , and declined to 28 in 1976 (Ministry of Planning, 1986). The 1982 Manpower Survey showed the unemployment rate to be $6.7 \%$. The official unemployment rate indicated by the Health, Nutrition, Manpower and Poverty Survey (1987) was 14.8\%.

\section{Chart $A-1$}

The Unemployment Rates (for Males and Females) During Selected Years

\begin{tabular}{lc} 
Year & Unemployment Rate \\
1961 & 14.1 \\
1970 & 8.0 \\
1973 & 2.0 \\
1976 & 6.7 \\
1982 & 8.0 \\
1985 & 14.8 \\
$1987 *$ & 17.1 \\
$1991 * *$ & \\
\hline
\end{tabular}

Source: Ministry of Planning, 1986.

* Health, Nutrition, Manpower and Poverty Survey Department of Statistics, Jordan, 1987.

** Ministry of Planning, 1993.

\section{Female Education}

According to Chart $A-2$, female illiteracy rate for those 15 years and over is $30.4 \%$. Females with post secondary education comprise 6.78 of the female population. These rates may partially explain the low female participation in the labor force. 
Chart A-2

Female Education (15+ years)

Health, Nutrition, Manpower and Poverty Survey, 1987

$\begin{array}{lr}\text { Education level Female Populatio } \\ \\ \text { Illiterate } & 30.4 \\ \text { Read \& Write } & 11.6 \\ \text { Elementary } & 21.0 \\ \text { Preparatory } & 19.4 \\ \text { Vocational Diploma } & 0.2 \\ \text { Secondary } & 10.5 \\ \text { Middle Diploma } & 5.2 \\ \text { University: BA \& BSC } & 1.4 \\ \text { Higher Studies } & 0.1\end{array}$

Source: Ministry of Planning, Jordan, 1987

School enrollment from the elementary to the secondary levels shows that $51 \%$ of students are male compared with 498 female (Department of statistics, 1986). As for the student enrollment after high school, the 1988 statistical Bulletin showed that $40 \%$ of all university students in Jordan are female. This does not include higher education students abroad, where the majority are males. At the community college level, $60 \%$ of the student population are female.

\section{Women in the Labor Force}

Participation in the Jordanian labor force varies according to sex and age. Although the crude labor force

participation rate in Jordan is very low compared to other developing countries, it is higher for males than females. The crude male labor force participation rate was $34.6 \%$ compared with a crude female labor force participation rate of only 4.3\%. In 1982, the male labor force participation rate among those aged 15 years and more was $67.8 \%$ while it was 8.48 among females (Department of statistics, 1984).

In 1987, females comprised $10.6 \%$ of the total labor force (Chart A-2) as opposed to $8.4 \%$ in 1982, and 7.7\% in 1979. In absolute numbers this reflects continuously increasing numbers of female workers. However, the refined activity rate (defined as the ratio of females, age 15 and over, who are economically active), was only 9\% in 1987. This does not match the increasing numbers of female population at 
working age, nor the increase in numbers of students graduating from secondary schools, community colleges, and universities. Entrants to the labor market remain predominantly male. Thus, the share of females in the labor force is not consistent with the level of development of the country.

\section{Chart A-3}

Distribution of Labor Force By Age Group and Sex Health, Nutrition, Manpower and Poverty Survey, 1987

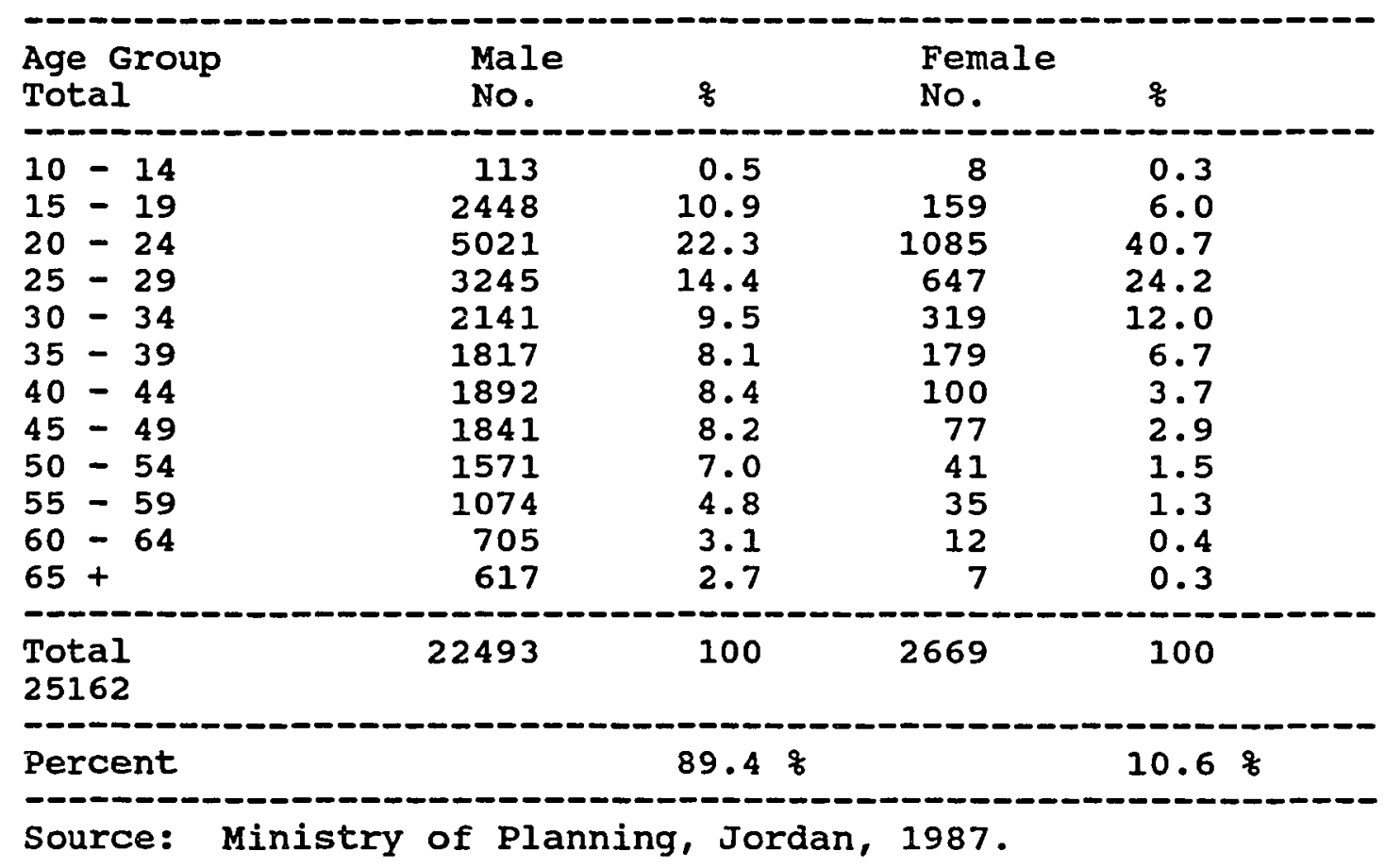

Education Rates for Females in the Labor Force

In Jordan, female employment trends are clearly influenced by female education. According to the 1987 Health, Nutrition, Manpower and Poverty Survey (Ministry of Planning, 1990), the female labor force is quite educated. Among the females employed in the formal sector, 55.7\% have diplomas and university degrees, compared with 15.7\% among the male workers (Chart A-4). Also the male workers who are illiterate or can only read and write are higher at $32.4 \%$ compared with $10.3 \%$ among the female workers. 
Chart $\mathrm{A}-4$

Distribution of Labor Force by Educational Level Health, Nutrition, Manpower and Poverty Survey, 1987

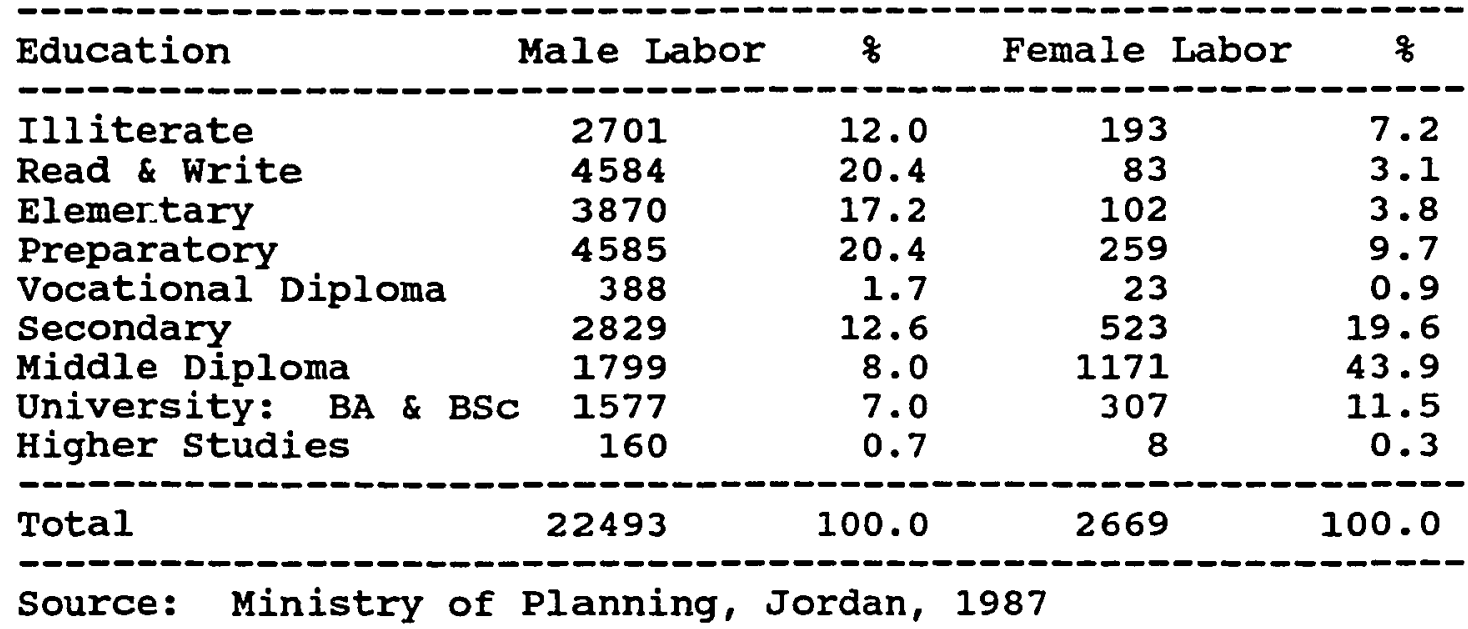

The distribution of the labor force by marital status shows that among the females, $67.6 \%$ are single, $27 \%$ are married and $5.3 \%$ are divorced or widowed. For men, the percentages are $38.9 \%, 60.5 \%$ and $0.5 \%$ respectively (Chart A-5).

Chart $\mathrm{A}-5$

Distribution of Labor Force by Marital status Health, Nutrition, Manpower and Poverty Survey, 1987

\begin{tabular}{|c|c|c|c|c|}
\hline Marital status & $\begin{array}{l}\text { Male } \\
\text { No. }\end{array}$ & $q$ & $\begin{array}{l}\text { Fem } \\
\text { No. }\end{array}$ & $\%$ \\
\hline $\begin{array}{l}\text { Single } \\
\text { Married } \\
\text { Divorced } \\
\text { Widowed }\end{array}$ & $\begin{array}{r}8760 \\
13603 \\
77 \\
53\end{array}$ & $\begin{array}{r}38.9 \\
60.5 \\
0.3 \\
0.2\end{array}$ & $\begin{array}{r}1805 \\
722 \\
56 \\
86\end{array}$ & $\begin{array}{r}67.6 \\
27.1 \\
2.1 \\
3.2\end{array}$ \\
\hline Total & 22493 & 100 & 2669 & 100 \\
\hline
\end{tabular}


Female Unemployment

In 1987 , the unemployment rate in Jordan was $15 \%$. Unemployment amorig the female labor force was $27 \%$ compared with $13 \%$ among males (Department of statistics, 1987). Moreover, for those seeking employment, the civil service Commission records for 1989 showed that $67 \%$ of the total number of applicants were female and $44.6 \%$ got appointed compared to $55.4 \%$ for the males (Chart $A-6$ ).

\section{Chart $\mathrm{A}-6$}

Applicants \& Appointees at the Civil Service Commission, 1989

\begin{tabular}{|c|c|c|c|c|}
\hline Education & & & Fer & lale \\
\hline & cants & Appointees & Applicants & Appointees \\
\hline $\begin{array}{l}\text { University } \\
\text { Comm College } \\
\text { Secondary }\end{array}$ & $\begin{array}{l}5908 \\
6698 \\
3382\end{array}$ & $\begin{array}{r}1233 \\
1192 \\
166\end{array}$ & $\begin{array}{r}5688 \\
23495 \\
3200\end{array}$ & $\begin{array}{r}1141 \\
890 \\
53\end{array}$ \\
\hline $\begin{array}{l}\text { Total } \\
\& \text { Applicants } \\
\& \text { Appointed }\end{array}$ & $\begin{array}{r}15988 \\
33 \\
55\end{array}$ & 2591 & $\begin{array}{r}32383 \\
67 \\
44\end{array}$ & 2084 \\
\hline
\end{tabular}

Source: Ministry of Planning, 1990.

\section{Wages Differentials}

According to the 1987 Health, Nutrition, Manpower and Poverty Survey, males get 27.98 more pay than females given equal education, age, residence, and experience (Ministry of Planning, 1990). Since the civil Service Law and the Labor Law do not, theoretically at least, discriminate between the sexes, wage differentiation is less evident in public sector jobs. However, in agriculture, industry as well as in private businesses, sex differences in wages are evident (Department of statistics, 1987).

The 1987 Health, Nutrition, Manpower and Poverty Survey (Department of statistics, 1987) yielded findings concerning the formal labor force. They are as follows:

While the population of Jordan is $70 \%$ urban and $30 \%$ rural, the male labor force participation reflects the same regional distribution. As for the female labor force, there is more concentration in the urban areas at $81.6 \%$. 
The highest proportion of workers are in the age group 20-24 years. For female workers, $40.7 \%$ are in this cohort as opposed to $22.3 \%$ for males. For females, a consistent drop in distribution gradually follows.

All statistics and figures presented above, refer to women's labor force participation in the formal sector of the economy. A report by the Manpower Planning Division of the Ministry of Planning (1990) emphasized that data pertaining to women's informal activities are non-existent. Although the report contends that women's work in the informal sector may comprise a substantial part of female economic role, no studies have been attempted to-date. Such studies would help to identify the scope of the informal sector, the array of economic activities carried out therein, and the conditions of the participants, both male and female.

The only study that looked into different-size industries and accounted for women's participation therein, was carried out by the Chamber of Industry in 1990. However, it is important to emphasize here that this categorization of small industries is not the informal sector, because these enterprises are registered by the chamber of Industry.

Nevertheless, it is interesting to highlight some of the major findings. Men constituted 95\% while women accounted for only $5 \%$ of the labor in these enterprises (Chart A-7). The smallest size enterprises, that employ 1 to 4 laborers, employed the majority of labor at $81 \%$. This may indicate the importance of the smaller size enterprises. Women's participation was positively correlated with the number of laborers in the enterprise. This may be reflecting a cultural consideration whereby it is not acceptable for a woman to work alone with men. 
Chart $A-7$

Industry size by

Number of Laborers

\begin{tabular}{|c|c|c|c|c|c|}
\hline $\begin{array}{l}\text { Industry Size } \\
\text { Number of } \\
\text { Laborers }\end{array}$ & $1-4$ & 5-9 & $10-19$ & $20+$ & Total \\
\hline $\begin{array}{l}\text { Number of } \\
\text { Institutions } \\
\frac{q}{\sigma}\end{array}$ & $\begin{array}{l}7933 \\
81.2\end{array}$ & $\begin{array}{l}1251 \\
12.8\end{array}$ & $\begin{array}{l}310 \\
3.17\end{array}$ & $\begin{array}{r}275 \\
2.82\end{array}$ & $\begin{array}{l}9769 \\
1008\end{array}$ \\
\hline $\begin{array}{l}\text { Number of } \\
\text { Laborers }\end{array}$ & $1-4$ & $5-9$ & $10-19$ & $20+$ & Total \\
\hline $\begin{array}{c}\underset{\text { Labor }}{\text { Male }} \\
\underset{\delta}{\text { L }}\end{array}$ & $\begin{array}{r}19880 \\
31.9 \\
99.3\end{array}$ & $\begin{array}{l}7379 \\
11.8 \\
96.2\end{array}$ & $\begin{array}{l}3810 \\
6.11 \\
94.6\end{array}$ & $\begin{array}{l}31260 \\
50.15 \\
91.7\end{array}$ & $\begin{array}{l}62329 \\
100 \% \\
94.78\end{array}$ \\
\hline $\begin{array}{l}\text { Female } \\
q\end{array}$ & $\begin{array}{l}137 \\
3.9 \\
0.7\end{array}$ & $\begin{array}{l}289 \\
8.3 \\
3.8\end{array}$ & $\begin{array}{l}216 \\
6.2 \\
5.4\end{array}$ & $\begin{array}{r}2845 \\
81.6 \\
8.3\end{array}$ & $\begin{array}{r}3487 \\
100 \% \\
5.3\end{array}$ \\
\hline$($ Total $\underset{q}{M} \& F)$ & $\begin{array}{r}20017 \\
30.4\end{array}$ & $\begin{array}{l}7668 \\
11.6\end{array}$ & $\begin{array}{r}4026 \\
6.2\end{array}$ & $\begin{array}{r}34105 \\
51.8\end{array}$ & $\begin{array}{l}65816 \\
1008\end{array}$ \\
\hline
\end{tabular}

Source: Chamber of Industry, 1990. 
APPENDIX B

QUESTIONNAIRE 
Interviewer

Date

Area

House No.

Telephone (if available)

\section{Adult Male Members}

Name

(Head or) Relation to Head of Household

Date of Birth

Place of Birth

Nationality

If student, specify current educational level

Otherwise, last educational attainment

Marital status: (1) Single, (2) Married, (3) Widowed,

(4) Divorced, (5) Separated.

Residence : (1) Owned (2) Rented; Monthly Rent

JD.

Summary sheet:

Number of Males over 15 years

Number of Males under 15 years

\section{Adult Female Members}

Name

Relation to Head of Household

Date of Birth

Place of Birth

Nationality

If student, specify current educational level

otherwise, last educational attainment

Mother's educational level

Marital status: (1) Single, (2) Married, (3) Widowed,

Age at Marriage

(4) Divorced, (5) Separated.

For ever-married women:

Number of children below 6 years

Number of children between $6 \& 15 \overline{\text { years }}$

$(*)$. 
(*) Do you have anyone to help you in domestic work \& child care?

No

Yes

Number

Relation

Ages

Household Adult Membership:

Number of Females over 15 years

Number of Females under 15 years

EMPLOYMENT INFORMATION

ADULT MALE MEMBERS

Area

House No.

Family No.

Employment Status:

1. Full-time

2. Part-time

3. Unemployed, looking for work

4. Unemployed, handicap or incapacity

5. Unemployed, old age

6. Student

Main occupation:

Name of institution:

Location of work: 1 . at home; 2 . in the community;

3. in Amman; 4. outside Amman.
(1) self employed;
(2) wage labor;
(3) unpaid labor

Monthly income from main occupation: JD.

Second occupation:

Monthly income from second occupation: JD.

Other sources of income:

Type

1. Rent

2. Property

3. Cash assistance from family

4. Official financial assistance

5. Other, specify:
Amourt per month

JD

JD

JD

JD

JD 
Area

House No.

Family No.

Employment status:

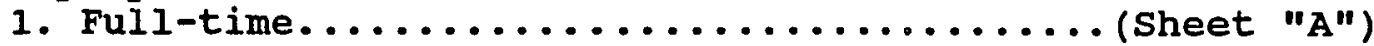

2. a. Part-time b. Daily c. Piece-work.... (Sheet "A")

3. Unemployed, looking for work................. (Sheet "B")

4. Unemployed, handicap or incapacity

5. Unemployed, old age

6. Student

7. Unemployed, not looking for work.......... (Sheet "C")

8. Housewife (in conjunction with another category above)

Main occupation:

Name of institution:

Location of work: 1 . at home; 2, in the community;

3. in Amman; 4. outside Amman.
(1) self employed;
(2) wage labor;
(3) unpaid labor

Monthly income from main occupation: JD.

Work environment: (1) mixed; (2) segregated--women only;

(3) inapplicable

How long in this occupation:

Training for this occupation:

Name of Institution:

Duration of training:

Second occupation:

Monthly income from second occupation:

JD.

other sources of income:

Type

1. Income from child labor

2. Cash assistance from family

3. Official financial assistance

4. Alimony in case of divorced woman

5. Other, specify:
Amount per month

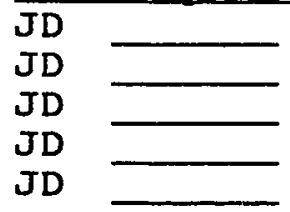


BHEET "A": WORKING WOMAN

Name

House No

Person No

What is/are the most important reason (two reasons) that 1 lead you to work?

1. I'm the sole income earner in the family

2. Husband unemployed

3. To supplement family income and improve standard of living

4. To support medical expenses for a family member (relation...)

5. To utilize the education I have acquired

6. To utilize certain training acquired, or certain skill

7. To utilize spare time

8. To get away from the home

9. Satisfaction of personal needs

10. Financial independence

11. Self actualization

12 . other, specify:

13.

Do you think your work and income contribution

..... (1) improve your status in the family?

Yes No Same

(2) improve your decision-making capacity? Yes No Same

Are there certain family expenses that you don't approve of? No Yes Specify: Smoking of husband or other family member

Alcohol consumption Gambling Expenditures for another family/ Another marriage/household (of the husband)

other, specify

For the women who works INSIDE THE HOME:

Are you satisfied with you home-based economic activity? Yes__ No __ Why? 
Why don't you work outside the home?

- Family objection

- Follow traditional role of housewife (homemaker; childbearer)

- Religion prohibits woman's work outside the home

- Norm and tradition prohibit woman's work outside the home

- Lack appropriate schooling (education)

- Lack appropriate skill training

- Domestic chores and responsibilities

- Care of pre-school children; number

- Special care of an incapacitated family member; Relation Illness

- Other: specify 
SHEET "B": NON-WORKING WOMAN / WHO WISHES TO WORR.

Name

House No

Person No

Have you applied for a job? No

Yes_ : at Government service office

at Labor service office

other, specify

What happened?

What are the most important reasons or obstacles that prohibit you from working?

1. Non-availability of a job or work opportunity

2. Availability of an unsuitable job:

2a. Place of work is far

$2 b$. Workplace is mixed (men and women)

2c. Remuneration is too little:

What is the minimum remuneration that you consider worth-while? JD per month.

3. Family objection to working outside the home

4. Lack appropriate schooling (education)

5. Lack appropriate skill training

6. Lack capital to start a private enterprise

other, specify:

7 .

8.

Do you think, that IF you worked and contributed to family income, you will acquire....

... (1) better status in the family? Yes_ No _ Same

... (2) better decision-making capacity? Yes_ No _ Same

Are there certain family expenses that you don't approve of? No Yes

specify: smoking of husband or other family member Alcohol consumption

Gambling

Expenditures for another family/specify... Another marriage/household (of the husband) other, specify. 
SHEET "B" (continue):

IF a work opportunity were available, what type will you choose?

A. Work (economic activity) inside the home;

specif $\ddot{y}$ :

B. Work outside the home:

1. Work through Save the children in the community

outside the community

2. Work in a similar income-generating project in the community outside the community

3. Beauty salon in the community _ outside the community

4. Nursing

5. Government job

6. Teaching

7. Private sector / Bank

8. Vocational training inst.

9. Job in a workshop/factory

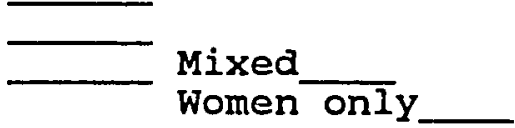

10. Work in a shop / store

11. Work in a restaurant

12. House-maid (cleaning)

13. Janitorial work school bank Women only

14. Other, specify

Are there undesired types of work/ jobs you refuse to undertake?

No ___: Would you take work outside the home? Yes No Would you take work in a mixed envt.? Yes No Would you take types 11, 12, 13 above? Yes No

Yes _ : What are they? Why? 
SHEET "C": NON-WORKING WONAN / WHO DOES NOT WISH TO WORK.

Name

House No

Person No

Why don't you work? (Give one or two most important reasons)

1. Family financial situation is satisfactory; no need for my work

2. Family objection to working outside the home

3. Follow traditional role of housewife (homemaker; childbearer)

4. Religion prohibits woman's work outside the home

5. Norm and tradition prohibit woman's work outside the home

6. Lack appropriate schooling (education)

7. Lack appropriate skill training

8. Domestic chores and responsibilities

9. Care of pre-school children; number

10. Special care of an incapacitated family member; Relation Illness

11. Lack of control over my income, in case I worked other, specify 12 .

13 .

Do you think, that IF you worked and contributed to family income,

you will acquire....

... (1) better status in the family?

Yes No Same

... (2) bet $\overline{t e r}$ decision-making capacity?

Yes_No_ Same

Are there certain family expenses that you don't approve of?

No___ Yes

Specify: Smoking of husband or other family

member

Alcohol consumption

Gambling

Expenditures for another family

specify......

Another marriage/household (of the husband)

other, specify 